\title{
Reversible Covalent Imine-Tethering for Selective Stabilization of 14-3-3 Hub Protein Interactions
}

Peter J Cossar ${ }^{1, \#}$, Madita Wolter ${ }^{1, \#}$, Lars van Dijck ${ }^{1}$, Dario Valenti' ${ }^{1,2}$, Laura M. Levy ${ }^{2}$, Christian Ottmann ${ }^{1 *}$ and Luc Brunsveld ${ }^{1 *}$

1. Laboratory of Chemical Biology, Department of Biomedical Engineering and Institute for Complex Molecular Systems, Eindhoven University of Technology, P.O. Box 513, 5600 MB Eindhoven (The Netherlands)

2. Taros Chemicals GmbH \& Co. KG, Emil-Figge-Straße 76a, 44227 Dortmund (Germany)

KEYWORDS Protein-Protein Interactions, Fragment-based drug discovery, covalent reversible molecular glues, Pin1, cooperativity

\section{Supporting Information}

\section{Contents}

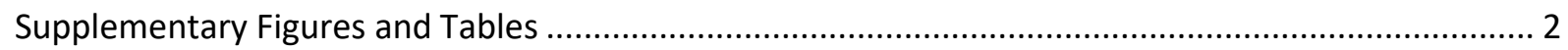

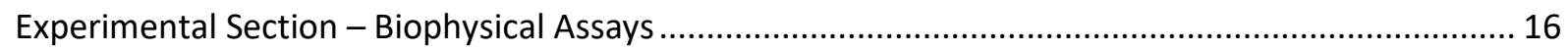

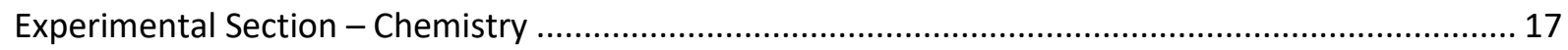

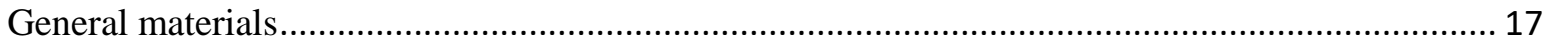

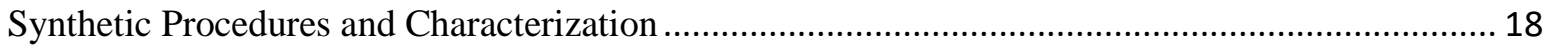

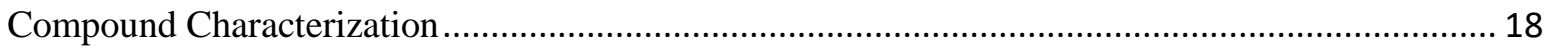

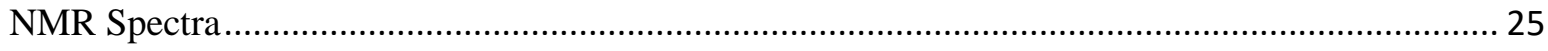

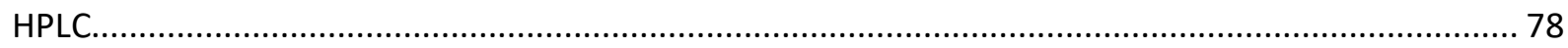

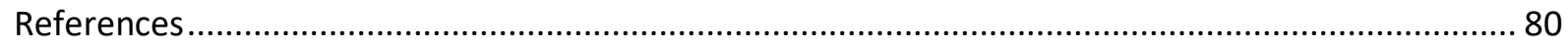




\section{Supplementary Figures and Tables}

Table S1: The 14-3-3pred server allows the in silico analysis of potential 14-3-3 binding sites of Pin1.

\begin{tabular}{cccccccc} 
Position & Peptide [-6:4] & \multicolumn{1}{c}{ ANN PSSM } & SVM & Consensus phosphoS/T \\
18 & EKRMSR[S]SGRV & 0.655 & 0.376 & -0.187 & 0.281 & - \\
19 & KRMSRS[S]GRVY & 0.236 & 0.172 & -0.741 & -0.111 & - \\
29 & YYFNHIT]NASQ & 0.112 & -0.118 & -1.135 & -0.380 & - \\
32 & NHITNA[S]QWER & 0.344 & 0.017 & -1.048 & -0.229 & - \\
38 & SQWERP[S]GNSS & 0.049 & -0.032 & -1.242 & -0.408 & - \\
41 & ERPSGN[S]SSGG & 0.062 & -0.107 & -1.383 & -0.476 & - \\
42 & RPSGNS[S]SGGK & 0.136 & -0.226 & -0.929 & -0.340 & - \\
43 & PSGNSS[S]GGKN & 0.147 & 0.033 & -0.636 & -0.152 & - \\
58 & PARVRC[S]HLLV & 0.525 & 0.332 & -0.614 & 0.081 & - \\
65 & HLLVKH[S]QSRR & 0.142 & -0.013 & -1.085 & -0.319 & - \\
67 & LVKHSQ[S]RRPS & 0.214 & -0.020 & -0.469 & -0.092 & - \\
71 & SQSRRP[S]SWRQ & 0.552 & 0.712 & -0.128 & 0.379 & - \\
72 & QSRRPS[S]WRQE & 0.583 & 0.821 & 0.370 & 0.591 & - \\
79 & WRQEKIT]RTKE & 0.118 & -0.035 & -1.168 & -0.362 & - \\
81 & QEKITR[T]KEEA & 0.114 & -0.035 & -1.036 & -0.319 & - \\
98 & YIQKIK[S]GEED & 0.519 & 0.214 & 0.162 & 0.298 & - \\
105 & GEEDFE[S]LASQ & 0.159 & -0.151 & -1.308 & -0.433 & - \\
108 & DFESLA[S]QFSD & 0.167 & -0.173 & -1.130 & -0.379 & - \\
111 & SLASQF[S]DCSS & 0.062 & -0.163 & -1.479 & -0.527 & - \\
114 & SQFSDC[S]SAKA & 0.069 & -0.328 & -1.607 & -0.622 & - \\
115 & QFSDCS[S]AKAR & 0.248 & 0.007 & -0.605 & -0.117 & - \\
126 & GDLGAF[S]RGQM & 0.262 & -0.048 & -0.479 & -0.088 & - \\
138 & KPFEDA[S]FALR & 0.152 & -0.078 & -1.023 & -0.316 & - \\
143 & ASFALR[T]GEMS & 0.050 & -0.369 & -1.800 & -0.706 & - \\
147 & LRTGEM[S]GPVF & 0.528 & 0.730 & 0.209 & 0.489 & - \\
152 & MSGPVF[T]DSGI & 0.200 & -0.067 & -0.747 & -0.205 & - \\
154 & GPVFTD[S]GIHI & 0.131 & -0.120 & -0.970 & -0.320 & - \\
162 & IHIILR[T]E--- & 0.118 & 0.148 & -1.347 & -0.360 & - \\
& & & - & - \\
\hline
\end{tabular}




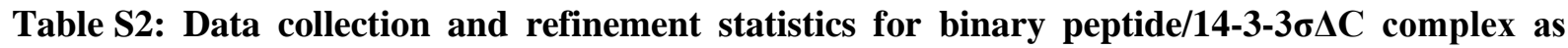
indicated. Data collection statistics, as reported by aimless, the refinement statics were derived from the 'Table1' software of the phenix suite. Values in parenthesis represent the highest resolution shell.

\begin{tabular}{|c|c|c|}
\hline & Pin1pS72 & AS160 \\
\hline PDB code & 7AOG & $7 \mathrm{NIX}$ \\
\hline X-ray source & DESY, Petra III, P11 & DLS, 103 \\
\hline \multicolumn{3}{|l|}{ Data Collection } \\
\hline Wavelength & 1.0332 & 0.976284 \\
\hline Resolution range & $\begin{array}{l}62.65-1.5 \\
(1.53-1.50)\end{array}$ & $\begin{array}{l}104.98-1.9 \\
(1.94-1.9)\end{array}$ \\
\hline Space group & C2221 & P6122 \\
\hline \multicolumn{3}{|l|}{ Unit cell } \\
\hline$a, b, c(\AA)$ & 82.43112 .0662 .65 & 121.22121 .2274 .46 \\
\hline$\alpha, \beta, \gamma\left(^{\circ}\right)$ & 90.0090 .0090 .00 & 90.0090 .00120 .00 \\
\hline Unique reflections & $44552(1508)$ & $25949(1623)$ \\
\hline Multiplicity & $10.5(3.8)$ & $37.5(38.7)$ \\
\hline Completeness (\%) & $95.1(64.3)$ & $100(100)$ \\
\hline Mean I/sigma(I) & $20.1(1.6)$ & $25.4(3.3)$ \\
\hline R-merge & $0.055(0.736)$ & $0.104(1.550)$ \\
\hline R-meas & $0.058(0.859)$ & $0.105(1.570)$ \\
\hline R-pim & $0.017(0.425)$ & $0.017(0.252)$ \\
\hline $\mathrm{CC} 1 / 2$ & $0.999(0.527)$ & $1.000(0.970)$ \\
\hline \multicolumn{3}{|l|}{ Refinement } \\
\hline Reflections used in refinement & $44518(3163)$ & $25890(2522)$ \\
\hline Reflections used for R-free & $2152(162)$ & $1244(117)$ \\
\hline R-work & $0.1653(0.2470)$ & $0.1856(0.2706)$ \\
\hline R-free & $0.1843(0.2549)$ & $0.2041(0.3141)$ \\
\hline No. of non-hydrogen atoms & 2258 & 2133 \\
\hline macromolecules & 1970 & 1908 \\
\hline ligands & 4 & 60 \\
\hline solvent & 284 & 197 \\
\hline RMS (bonds) & 0.008 & 0.005 \\
\hline RMS (angles) & 0.91 & 0.81 \\
\hline Ramachandran favored (\%) & 97.87 & 99.14 \\
\hline Ramachandran allowed (\%) & 2.13 & 0.86 \\
\hline Ramachandran outliers (\%) & 0 & 0 \\
\hline Rotamer outliers (\%) & 0 & 0 \\
\hline Clashscore & 3.1 & 1.32 \\
\hline Average B-factor & 24.98 & 34.39 \\
\hline macromolecules & 23.54 & 33.34 \\
\hline ligands & 30.26 & 49.65 \\
\hline solvent & 34.88 & 42.4 \\
\hline
\end{tabular}




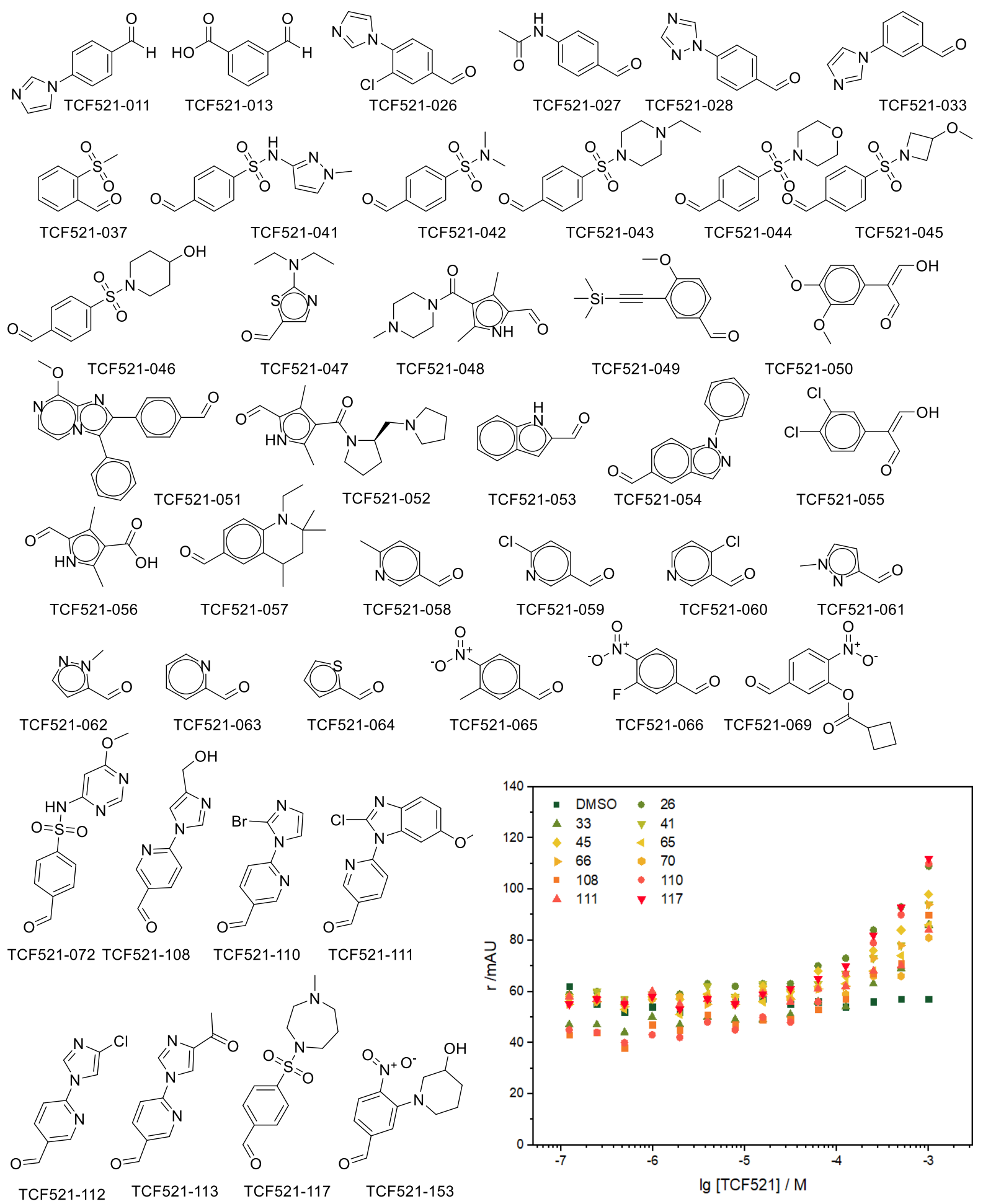

Figure S1: Imine tethering screen of an aldehyde library revealed 11 hit fragments. Stabilization

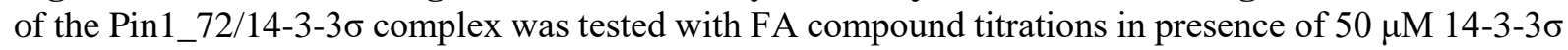
and 100 nM Pin1_72. 


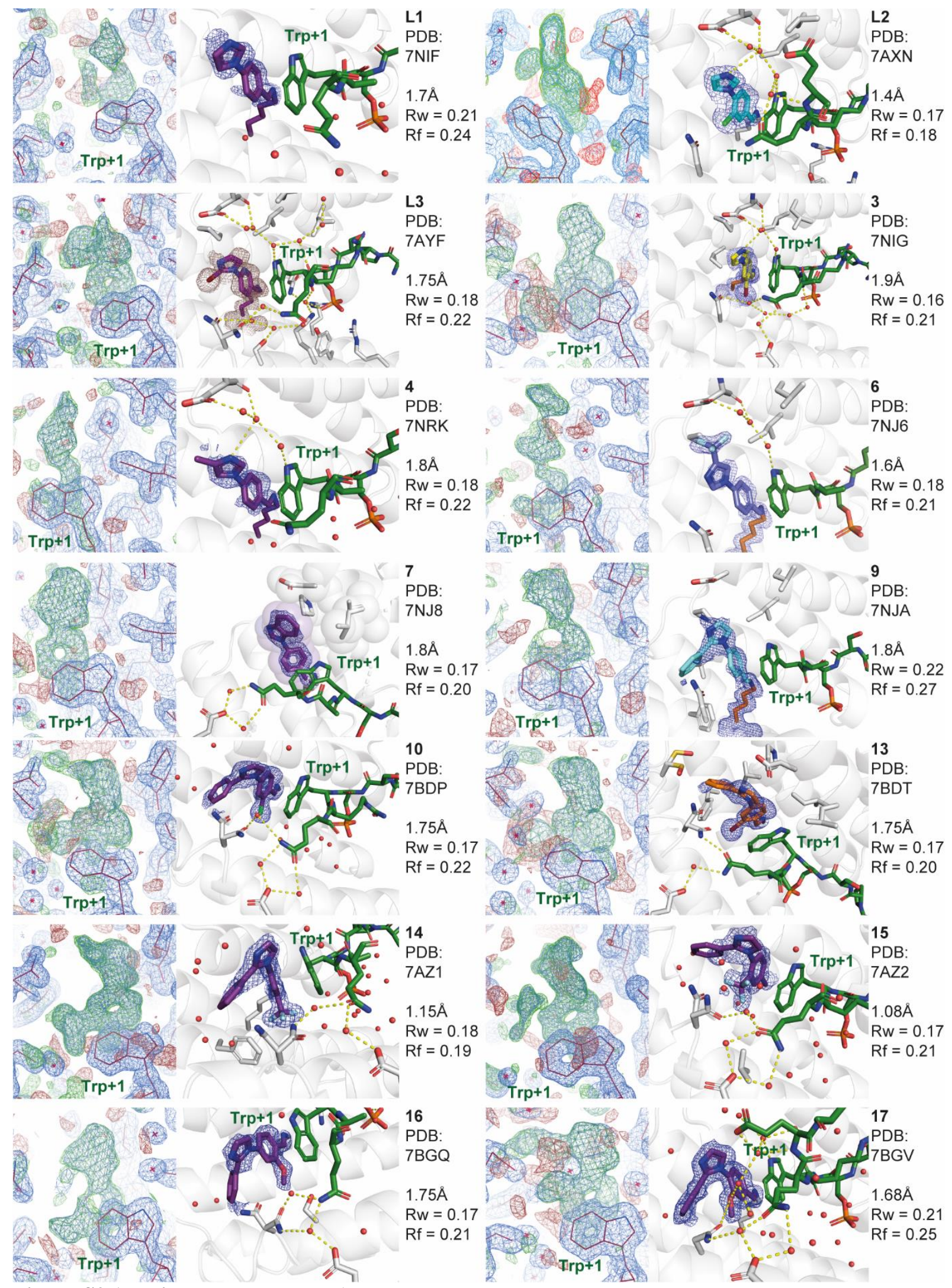

Figure S2 (continued on next page). 


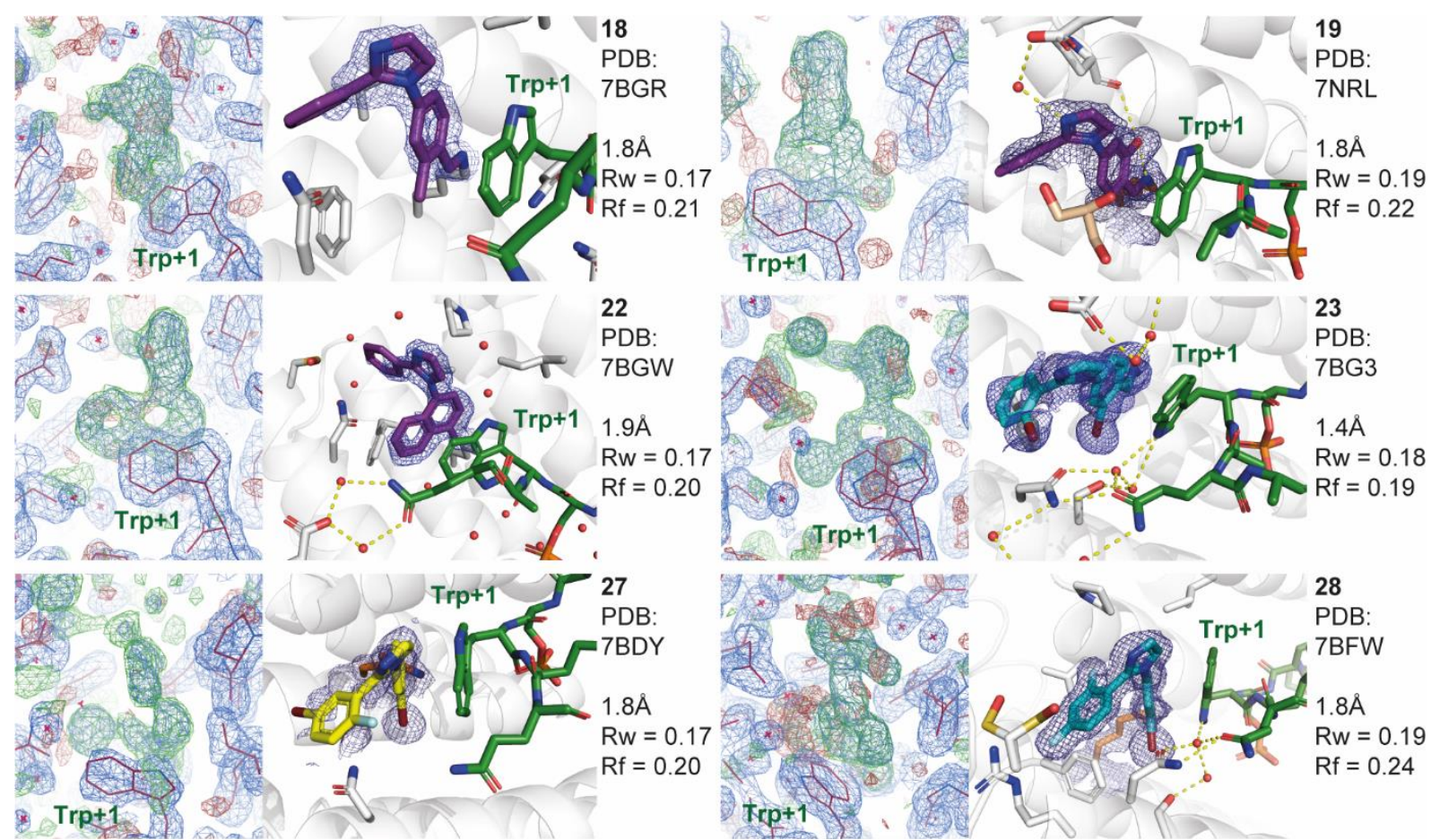

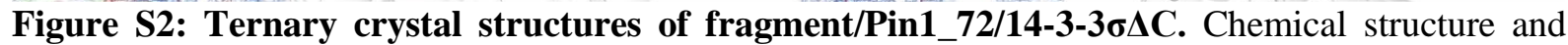
biophysical activity of the fragments are listed in Table 1 and additional crystallographic statistics are listed in Table S3. Indicated are the unbiased electron density in absence of fragment coordinates as provided by coot (left, blue 2Fo-Fc map: rmsd=1, green/red Fo-Fc map: rmsd=2.5), the binding pose of the in-built fragment (middle, colour legend see below) and the compound number, PDB ID, high-

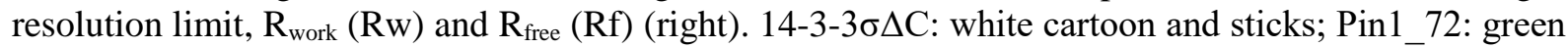
cartoon; water: red spheres; hydrogen bonds: yellow dashes. $2 \mathrm{Fo}-\mathrm{Fc}$ electron density map at $1 \sigma$ : blue mesh. 


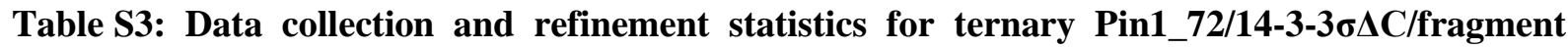
complex as indicated. Data collection statistics, as reported by aimless, the refinement statics were derived from the 'Table1' software of the phenix suite. Values in parenthesis represent the highest resolution shell.

\begin{tabular}{|c|c|c|c|c|c|c|}
\hline Compound number & L1 & $\mathbf{L 2}$ & L3 & 3 & 4 & 6 \\
\hline PDB code & 7NIF & $7 \mathrm{AXN}$ & 7AYF & $7 N I G$ & 7NRK & 7NJ6 \\
\hline X-ray source & homesource & DLS, 103 & homesource & homesource & homesource & homesource \\
\hline \multicolumn{7}{|l|}{ Data Collection } \\
\hline Wavelength & 1.54187 & 0.97625 & 1.54187 & 1.54187 & 1.54187 & 1.54187 \\
\hline Resolution range & $\begin{array}{l}33.19-1.71 \\
(1.74-1.71)\end{array}$ & $\begin{array}{l}66.16-1.4 \\
(1.42-1.40)\end{array}$ & $\begin{array}{l}33.16-1.75 \\
(1.78-1.75)\end{array}$ & $\begin{array}{l}41.68-1.90 \\
(1.93-1.90)\end{array}$ & $\begin{array}{l}33.98-1.75 \\
(1.78-1.75)\end{array}$ & $\begin{array}{l}33.16-1.59 \\
(1.61-1.59)\end{array}$ \\
\hline Space group & C2221 & C2221 & C2221 & C2221 & C2221 & C2221 \\
\hline \multicolumn{7}{|l|}{ Unit cell } \\
\hline$a, b, c(\AA)$ & $\begin{array}{l}82.39112 .05 \\
62.53\end{array}$ & $\begin{array}{l}82.03111 .94 \\
62.47\end{array}$ & $\begin{array}{l}82.31112 .00 \\
62.67\end{array}$ & $\begin{array}{l}82.09111 .58 \\
62.69\end{array}$ & $\begin{array}{l}82.25111 .96 \\
62.45\end{array}$ & $\begin{array}{l}82.33111 .91 \\
62.59\end{array}$ \\
\hline$\alpha, \beta, \gamma\left({ }^{\circ}\right)$ & $\begin{array}{l}90.0090 .00 \\
90.00\end{array}$ & $\begin{array}{l}90.0090 .00 \\
90.00\end{array}$ & $\begin{array}{l}90.0090 .00 \\
90.00\end{array}$ & $\begin{array}{l}90.0090 .00 \\
90.00\end{array}$ & $\begin{array}{l}90.0090 .00 \\
90.00\end{array}$ & $\begin{array}{l}90.0090 .00 \\
90.00\end{array}$ \\
\hline Unique reflections & $29170(761)$ & $54952(2050)$ & 28956 (1089) & $22988(1103)$ & 28225 (1321) & $32592(99)$ \\
\hline Multiplicity & $5.8(3.5)$ & $1.9(1.9)$ & $6.0(3.7)$ & $6.3(5.7)$ & $6.1(3.5)$ & $5.6(1.1)$ \\
\hline Completeness (\%) & $92.6(48.7)$ & $96.6(73.8)$ & $98.1(74.0)$ & $99.9(97.5)$ & $96.0(82.3)$ & $82.5(5.1)$ \\
\hline Mean I/sigma(I) & $5.7(1.1)$ & $16.2(2.1)$ & $7.9(1.8)$ & $16.5(5.9)$ & $13.2(2.3)$ & $14.1(1.7)$ \\
\hline R-merge & $0.210(0.779)$ & $0.014(0.241)$ & $0.161(0.641)$ & $0.082(0.286)$ & $0.099(0.468)$ & $0.082(0.222)$ \\
\hline R-meas & $0.231(0.919)$ & $0.020(0.341)$ & $0.176(0.738)$ & $0.089(0.315)$ & $0.109(0.548)$ & $0.089(0.314)$ \\
\hline R-pim & $0.129(0.588)$ & $0.014(0.241)$ & $0.070(0.356)$ & $0.035(0.131)$ & $0.043(0.279)$ & $0.036(0.222)$ \\
\hline $\mathrm{CC} 1 / 2$ & $0.987(0.549)$ & $1.000(0.870)$ & $0.993(0.673)$ & $0.998(0.956)$ & $0.997(0.838)$ & $0.998(0.927)$ \\
\hline \multicolumn{7}{|l|}{ Refinement } \\
\hline $\begin{array}{l}\text { Reflections used in } \\
\text { refinement }\end{array}$ & $29124(1693)$ & 54936 (4297) & $28932(2351)$ & $22968(2228)$ & $28193(2430)$ & $32565(483)$ \\
\hline $\begin{array}{l}\text { Reflections used for } \\
\text { R-free }\end{array}$ & $1461(83)$ & $2722(234)$ & $1482(119)$ & $1185(103)$ & 1409 (121) & $1628(25)$ \\
\hline R-work & $\begin{array}{l}0.2109 \\
(0.2671)\end{array}$ & $\begin{array}{l}0.1655 \\
(0.2436)\end{array}$ & $\begin{array}{l}0.1752 \\
(0.2182)\end{array}$ & $\begin{array}{l}0.1649 \\
(0.1739)\end{array}$ & $\begin{array}{l}0.1829 \\
(0.2411)\end{array}$ & $\begin{array}{l}0.1814 \\
(0.2495)\end{array}$ \\
\hline R-free & $\begin{array}{l}0.2392 \\
(0.3134)\end{array}$ & $\begin{array}{l}0.1822 \\
(0.2639)\end{array}$ & $\begin{array}{l}0.2176 \\
(0.2674) \\
\end{array}$ & $\begin{array}{l}0.2053 \\
(0.2133) \\
\end{array}$ & $\begin{array}{l}0.2157 \\
(0.2693) \\
\end{array}$ & $\begin{array}{l}0.2070 \\
(0.3067) \\
\end{array}$ \\
\hline $\begin{array}{l}\text { Number of non- } \\
\text { hydrogen atoms }\end{array}$ & 2239 & 2403 & 2297 & 2261 & 2200 & 2283 \\
\hline macromolecules & 1883 & 2045 & 1904 & 1924 & 1865 & 1918 \\
\hline ligands & 15 & 18 & 14 & 16 & 29 & 17 \\
\hline solvent & 341 & 340 & 379 & 321 & 306 & 348 \\
\hline RMS (bonds) & 0.004 & 0.015 & 0.006 & 0.005 & 0.004 & 0.003 \\
\hline RMS (angles) & 0.69 & 1.37 & 0.76 & 0.81 & 0.7 & 0.61 \\
\hline $\begin{array}{l}\text { Ramachandran } \\
\text { favored (\%) }\end{array}$ & 97.76 & 97.84 & 98.21 & 98.21 & 98.2 & 98.2 \\
\hline $\begin{array}{l}\text { Ramachandran } \\
\text { allowed (\%) }\end{array}$ & 2.24 & 2.16 & 1.79 & 1.79 & 1.8 & 1.8 \\
\hline $\begin{array}{l}\text { Ramachandran } \\
\text { outliers (\%) }\end{array}$ & 0 & 0 & 0 & 0 & 0 & 0 \\
\hline $\begin{array}{l}\text { Rotamer outliers } \\
\text { (\%) }\end{array}$ & 0 & 0 & 0 & 0 & 0 & 0 \\
\hline Clashscore & 3.76 & 1.73 & 1.06 & 2.88 & 1.35 & 1.84 \\
\hline Average B-factor & 14.89 & 21.94 & 15.03 & 14.89 & 14.77 & 15.37 \\
\hline macromolecules & 12.84 & 20.1 & 12.51 & 12.86 & 12.73 & 13.13 \\
\hline ligands & 33.17 & 25.73 & 29.04 & 21.47 & 35.66 & 39.9 \\
\hline solvent & 25.37 & 32.78 & 27.17 & 26.69 & 25.22 & 26.5 \\
\hline
\end{tabular}


Table S3 (continued): Data collection and refinement statistics for ternary Pin1_72/14-3$3 \sigma \Delta \mathbf{C}$ /fragment complex as indicated. Data collection statistics, as reported by aimless, the refinement statics were derived from the 'Table1' software of the phenix suite. Values in parenthesis represent the highest resolution shell.

\begin{tabular}{|c|c|c|c|c|c|c|}
\hline Compound number & 7 & 9 & 10 & 13 & 14 & 15 \\
\hline PDB code & 7NJ8 & 7NJA & 7BDP & 7BDT & 7AZ1 & $7 A Z 2$ \\
\hline X-ray source & homesource & homesource & homesource & homesource & DLS, 103 & DLS, 103 \\
\hline \multicolumn{7}{|l|}{ Data Collection } \\
\hline Wavelength & 1.54187 & 1.54187 & 1.54187 & 1.54187 & 0.97627 & 0.97627 \\
\hline Resolution range & $\begin{array}{l}34.07-1.80 \\
(1.83-1.80)\end{array}$ & $\begin{array}{l}25.58-1.75 \\
(1.78-1.75)\end{array}$ & $\begin{array}{l}41.63-1.75 \\
(1.78-1.75)\end{array}$ & $\begin{array}{l}33.97-1.75 \\
(1.78-1.75)\end{array}$ & $\begin{array}{l}45.44-1.15 \\
(1.17-1.15)\end{array}$ & $\begin{array}{l}66.24-1.08 \\
(1.10-1.08)\end{array}$ \\
\hline Space group & C2221 & C2221 & C2221 & C2221 & C2221 & C2221 \\
\hline \multicolumn{7}{|l|}{ Unit cell } \\
\hline$a, b, c(\AA)$ & $\begin{array}{l}82.39112 .24 \\
62.58\end{array}$ & $\begin{array}{l}82.40112 .10 \\
62.62\end{array}$ & $\begin{array}{l}81.99111 .69 \\
62.46\end{array}$ & $\begin{array}{l}82.10111 .95 \\
62.57\end{array}$ & $\begin{array}{l}82.25111 .75 \\
62.46\end{array}$ & $\begin{array}{l}82.14112 .02 \\
62.46\end{array}$ \\
\hline$\alpha, \beta, \gamma\left({ }^{\circ}\right)$ & $\begin{array}{l}90.0090 .00 \\
90.00\end{array}$ & $\begin{array}{l}90.0090 .00 \\
90.00\end{array}$ & $\begin{array}{l}90.0090 .00 \\
90.00\end{array}$ & $\begin{array}{l}90.0090 .00 \\
90.00\end{array}$ & $\begin{array}{l}90.0090 .00 \\
90.00\end{array}$ & $\begin{array}{l}90.0090 .00 \\
90.00\end{array}$ \\
\hline Unique reflections & $26776(1261)$ & 28879 (1275) & 28431 (1383) & $26997(888)$ & $\begin{array}{l}101961 \\
(4964)\end{array}$ & $\begin{array}{l}119445 \\
(4601)\end{array}$ \\
\hline Multiplicity & $6.2(5.1)$ & $5.5(3.3)$ & $6.1(3.3)$ & $6.4(5.2)$ & $1.9(2.0)$ & $1.9(2.0)$ \\
\hline Completeness (\%) & $98.4(92.4)$ & $97.5(78.6)$ & $97.1(86.8)$ & $91.9(56.6)$ & $100.0(99.6)$ & $97.4(76.9)$ \\
\hline Mean I/sigma(I) & $17.7(4.8)$ & $5.5(1.1)$ & $17.3(2.8)$ & $16.2(3.3)$ & $11.8(1.5)$ & $14.1(1.2)$ \\
\hline R-merge & $0.069(0.292)$ & $0.231(0.737)$ & $0.074(0.401)$ & $0.086(0.449)$ & $0.017(0.386)$ & $0.027(0.684)$ \\
\hline R-meas & $0.075(0.324)$ & $0.254(0.871)$ & $0.080(0.476)$ & $0.094(0.496)$ & $0.024(0.546)$ & $0.039(0.967)$ \\
\hline R-pim & $0.041(0.185)$ & $0.104(0.449)$ & $0.032(0.251)$ & $0.036(0.205)$ & $0.017(0.386)$ & $0.027(0.684)$ \\
\hline $\mathrm{CC} 1 / 2$ & $0.999(0.952)$ & $0.983(0.453)$ & $0.999(0.836)$ & $0.998(0.865)$ & $1.000(0.737)$ & $0.999(0.425)$ \\
\hline \multicolumn{7}{|l|}{ Refinement } \\
\hline $\begin{array}{l}\text { Reflections used in } \\
\text { refinement }\end{array}$ & 26759 (2512) & 28844 (2401) & $28411(2540)$ & 26989 (1826) & $\begin{array}{l}101942 \\
(10061)\end{array}$ & $\begin{array}{l}119245 \\
(9834)\end{array}$ \\
\hline $\begin{array}{l}\text { Reflections used for } \\
\text { R-free }\end{array}$ & $1356(127)$ & $1472(138)$ & $1427(124)$ & $1349(90)$ & $5038(481)$ & $5967(514)$ \\
\hline R-work & $\begin{array}{l}0.1709 \\
(0.1856) \\
\end{array}$ & $\begin{array}{l}0.2204 \\
(0.3435) \\
\end{array}$ & $\begin{array}{l}0.1725 \\
(0.2553) \\
\end{array}$ & $\begin{array}{l}0.1694 \\
(0.2143) \\
\end{array}$ & $\begin{array}{l}0.1827 \\
(0.2843) \\
\end{array}$ & $\begin{array}{l}0.1846 \\
(0.3308) \\
\end{array}$ \\
\hline R-free & $\begin{array}{l}0.2006 \\
(0.2225) \\
\end{array}$ & $\begin{array}{l}0.2659 \\
(0.4053) \\
\end{array}$ & $\begin{array}{l}0.2164 \\
(0.3028) \\
\end{array}$ & $\begin{array}{l}0.2015 \\
(0.2572) \\
\end{array}$ & $\begin{array}{l}0.1925 \\
(0.2969) \\
\end{array}$ & $\begin{array}{l}0.1973 \\
(0.3373) \\
\end{array}$ \\
\hline $\begin{array}{l}\text { Number of non- } \\
\text { hydrogen atoms }\end{array}$ & 2278 & 2244 & 2247 & 2297 & 2380 & 2364 \\
\hline macromolecules & 1908 & 1880 & 1899 & 1941 & 2011 & 1987 \\
\hline ligands & 18 & 19 & 20 & 20 & 25 & 25 \\
\hline solvent & 352 & 345 & 328 & 336 & 344 & 352 \\
\hline RMS(bonds) & 0.008 & 0.007 & 0.006 & 0.006 & 0.005 & 0.005 \\
\hline RMS(angles) & 0.95 & 0.88 & 0.8 & 0.82 & 0.76 & 0.73 \\
\hline $\begin{array}{l}\text { Ramachandran } \\
\text { favored (\%) }\end{array}$ & 98.2 & 98.2 & 98.21 & 98.21 & 97.8 & 98.22 \\
\hline $\begin{array}{l}\text { Ramachandran } \\
\text { allowed (\%) }\end{array}$ & 1.8 & 1.8 & 1.79 & 1.79 & 2.2 & 1.78 \\
\hline $\begin{array}{l}\text { Ramachandran } \\
\text { outliers (\%) }\end{array}$ & 0 & 0 & 0 & 0 & 0 & 0 \\
\hline $\begin{array}{l}\text { Rotamer outliers } \\
\text { (\%) }\end{array}$ & 0.5 & 0 & 0 & 0 & 0.47 & 0 \\
\hline Clashscore & 2.65 & 3.22 & 3.98 & 3.37 & 3 & 2.28 \\
\hline Average B-factor & 15.97 & 14.03 & 16.83 & 16.82 & 19.5 & 21.12 \\
\hline macromolecules & 13.74 & 11.81 & 14.8 & 14.75 & 17.24 & 18.61 \\
\hline ligands & 26.85 & 36.59 & 21.6 & 23.34 & 26.15 & 40.63 \\
\hline solvent & 27.49 & 24.85 & 28.31 & 28.38 & 32.24 & 33.92 \\
\hline
\end{tabular}


Table S3 (continued): Data collection and refinement statistics for ternary Pin1_72/14-3$3 \sigma \Delta \mathbf{C}$ /fragment complex as indicated. Data collection statistics, as reported by aimless, the refinement statics were derived from the 'Table1' software of the phenix suite. Values in parenthesis represent the highest resolution shell.

\begin{tabular}{|c|c|c|c|c|c|c|}
\hline Compound number & 16 & 17 & 18 & 19 & 22 & 23 \\
\hline PDB code & $7 B G Q$ & 7BGV & 7BGR & $7 \mathrm{NRL}$ & 7BGW & 7BG3 \\
\hline $\mathrm{X}$-ray source & homesource & homesource & homesource & homesource & homesource & $\begin{array}{l}\text { DESY, Petra } \\
\text { III, P11 }\end{array}$ \\
\hline \multicolumn{7}{|l|}{ Data Collection } \\
\hline Wavelength & 1.54187 & 1.54187 & 1.54187 & 1.54187 & 1.54187 & 1.0332 \\
\hline Resolution range & $\begin{array}{l}34.36-1.75 \\
(1.78-1.75)\end{array}$ & $\begin{array}{l}41.26-1.68 \\
(1.71-1.68)\end{array}$ & $\begin{array}{l}34.32-1.8 \\
(1.84-1.8)\end{array}$ & $\begin{array}{l}41.26-1.80 \\
(1.85-1.80)\end{array}$ & $\begin{array}{l}34.42-1.90 \\
(1.94-1.90)\end{array}$ & $\begin{array}{l}66.29-1.4 \\
(1.42-1.40)\end{array}$ \\
\hline Space group & C2221 & C2221 & C2221 & C2221 & C2221 & C2221 \\
\hline \multicolumn{7}{|l|}{ Unit cell } \\
\hline$a, b, c(\AA)$ & $\begin{array}{l}82.30111 .93 \\
62.43\end{array}$ & $\begin{array}{l}82.51112 .53 \\
62.78\end{array}$ & $\begin{array}{l}82.19111 .68 \\
62.39\end{array}$ & $\begin{array}{l}82.53112 .48 \\
62.52\end{array}$ & $\begin{array}{l}82.45111 .79 \\
62.56\end{array}$ & $\begin{array}{l}82.15112 .21 \\
62.80\end{array}$ \\
\hline$\alpha, \beta, \gamma\left({ }^{\circ}\right)$ & $\begin{array}{l}90.0090 .00 \\
90.00\end{array}$ & $\begin{array}{l}90.0090 .00 \\
90.00\end{array}$ & $\begin{array}{l}90.0090 .00 \\
90.00\end{array}$ & $\begin{array}{l}90.0090 .00 \\
90.00\end{array}$ & $\begin{array}{l}90.0090 .00 \\
90.00\end{array}$ & $\begin{array}{l}90.0090 .00 \\
90.00\end{array}$ \\
\hline Unique reflections & 29095 (1337) & $31746(1012)$ & 26985 (1548) & 27292 (1947) & 22305 (1370) & $57149(2617)$ \\
\hline Multiplicity & $5.9(3.4)$ & $5.4(1.8)$ & $6.1(4.8)$ & $6.0(4.5)$ & $6.5(6.2)$ & $12.1(7.1)$ \\
\hline Completeness (\%) & $98.8(82.8)$ & $94.8(61.5)$ & $99.9(98.1)$ & $99.8(97.7)$ & $96.4(92.5)$ & $99.6(93.8)$ \\
\hline Mean I/sigma(I) & $15.6(4.0)$ & $5.7(0.9)$ & $16.8(4.2)$ & $12.1(3.2)$ & $13.3(7.2)$ & $21.7(2.5)$ \\
\hline R-merge & $0.070(0.278)$ & $0.145(0.646)$ & $0.076(0.316)$ & $0.100(0.410)$ & $0.094(0.362)$ & $0.056(0.692)$ \\
\hline R-meas & $0.076(0.323)$ & $0.175(0.912)$ & $0.083(0.355)$ & $0.109(0.464)$ & $0.102(0.394)$ & $0.058(0.692)$ \\
\hline R-pim & $0.030(0.161)$ & $0.096(0.644)$ & $0.033(0.159)$ & $0.044(0.212)$ & $0.039(0.154)$ & $0.016(0.251)$ \\
\hline $\mathrm{CC} 1 / 2$ & $0.999(0.936)$ & $0.991(0.681)$ & $0.998(0.933)$ & $0.997(0.895)$ & $0.997(0.876)$ & $0.999(0.847)$ \\
\hline \multicolumn{7}{|l|}{ Refinement } \\
\hline $\begin{array}{l}\text { Reflections used in } \\
\text { refinement }\end{array}$ & 29049 (2543) & $31700(2300)$ & $26955(2636)$ & $27208(2608)$ & 22296 (2109) & $57119(5412)$ \\
\hline $\begin{array}{l}\text { Reflections used for } \\
\text { R-free }\end{array}$ & 1454 (129) & $1653(132)$ & 1359 (149) & $1377(119)$ & $1148(94)$ & $2838(287)$ \\
\hline R-work & $\begin{array}{l}0.1713 \\
(0.2091) \\
\end{array}$ & $\begin{array}{l}0.2130 \\
(0.2863) \\
\end{array}$ & $\begin{array}{l}0.1699 \\
(0.2155) \\
\end{array}$ & $\begin{array}{l}0.1860 \\
(0.2473) \\
\end{array}$ & $\begin{array}{l}0.1723 \\
(0.2152) \\
\end{array}$ & $\begin{array}{l}0.1770 \\
(0.2486) \\
\end{array}$ \\
\hline R-free & $\begin{array}{l}0.2076 \\
(0.2533) \\
\end{array}$ & $\begin{array}{l}0.2456 \\
(0.3039) \\
\end{array}$ & $\begin{array}{l}0.2110 \\
(0.2506)\end{array}$ & $\begin{array}{l}0.2249 \\
(0.2953) \\
\end{array}$ & $\begin{array}{l}0.2030 \\
(0.2399) \\
\end{array}$ & $\begin{array}{l}0.1896 \\
(0.2593) \\
\end{array}$ \\
\hline $\begin{array}{l}\text { Number of non- } \\
\text { hydrogen atoms }\end{array}$ & 2310 & 2250 & 2230 & 2304 & 2236 & 2353 \\
\hline macromolecules & 1926 & 1888 & 1898 & 1909 & 1863 & 2022 \\
\hline ligands & 24 & 23 & 21 & 84 & 26 & 22 \\
\hline solvent & 360 & 339 & 311 & 311 & 347 & 309 \\
\hline RMS(bonds) & 0.006 & 0.002 & 0.006 & 0.012 & 0.006 & 0.006 \\
\hline RMS(angles) & 0.79 & 0.45 & 0.77 & 1.13 & 0.76 & 0.79 \\
\hline $\begin{array}{l}\text { Ramachandran } \\
\text { favored (\%) }\end{array}$ & 98.21 & 98.23 & 98.21 & 98.21 & 97.76 & 97.37 \\
\hline $\begin{array}{l}\text { Ramachandran } \\
\text { allowed (\%) }\end{array}$ & 1.79 & 1.77 & 1.79 & 1.79 & 2.24 & 2.63 \\
\hline $\begin{array}{l}\text { Ramachandran } \\
\text { outliers (\%) }\end{array}$ & 0 & 0 & 0 & 0 & 0 & 0 \\
\hline $\begin{array}{l}\text { Rotamer outliers } \\
\text { (\%) }\end{array}$ & 0 & 0 & 0 & 0 & 0 & 0 \\
\hline Clashscore & 2.6 & 1.86 & 3.97 & 6.16 & 1.62 & 2.74 \\
\hline Average B-factor & 16.39 & 17.06 & 16.47 & 16.66 & 14.32 & 21.34 \\
\hline macromolecules & 13.99 & 15.23 & 14.47 & 13.98 & 12.12 & 19.65 \\
\hline ligands & 31.53 & 19.6 & 31.96 & 42.24 & 26.41 & 29.21 \\
\hline solvent & 28.26 & 27.06 & 27.64 & 26.14 & 25.22 & 31.87 \\
\hline
\end{tabular}


Table S3 (continued): Data collection and refinement statistics for ternary Pin1_72/14-3$\mathbf{3 \sigma} \Delta \mathbf{C}$ /fragment complex as indicated. Data collection statistics, as reported by aimless, the refinement statics were derived from the 'Table1' software of the phenix suite. Values in parenthesis represent the highest resolution shell.

\begin{tabular}{|c|c|c|}
\hline $\begin{array}{l}\text { Compound } \\
\text { Number }\end{array}$ & 27 & 28 \\
\hline PDB code & 7BDY & 7BFW \\
\hline X-ray source & homesource & homesource \\
\hline \multicolumn{3}{|l|}{ Data Collection } \\
\hline Wavelength & 1.54187 & 1.54187 \\
\hline Resolution range & $\begin{array}{l}41.15-1.8 \\
(1.85-1.8)\end{array}$ & $\begin{array}{l}40.98-1.8 \\
(1.85-1.80)\end{array}$ \\
\hline Space group & C2221 & C2221 \\
\hline \multicolumn{3}{|l|}{ Unit cell } \\
\hline$a, b, c(\AA)$ & $\begin{array}{l}82.19111 .89 \\
62.49\end{array}$ & $\begin{array}{l}81.96112 .15 \\
62.53\end{array}$ \\
\hline$\alpha, \beta, \gamma\left({ }^{\circ}\right)$ & $\begin{array}{l}90.0090 .00 \\
90.00\end{array}$ & $\begin{array}{l}90.0090 .00 \\
90.00\end{array}$ \\
\hline Unique reflections & 26632 (1829) & 26869 (1895) \\
\hline Multiplicity & $6.2(5.3)$ & $5.2(4.1)$ \\
\hline Completeness (\%) & $98.4(93.6)$ & $99.2(96.7)$ \\
\hline Mean I/sigma(I) & $24.3(8.9)$ & $6.7(1.3)$ \\
\hline R-merge & $0.050(0.149)$ & $0.153(0.698)$ \\
\hline R-meas & $0.54(0.165)$ & $0.170(0.796)$ \\
\hline R-pim & $0.021(0.069)$ & $0.072(0.373)$ \\
\hline $\mathrm{CC} 1 / 2$ & $0.999(0.988)$ & $0.989(0.861)$ \\
\hline \multicolumn{3}{|l|}{ Refinement } \\
\hline $\begin{array}{l}\text { Reflections used in } \\
\text { refinement }\end{array}$ & $26620(2496)$ & $26833(2557)$ \\
\hline $\begin{array}{l}\text { Reflections used for } \\
\text { R-free }\end{array}$ & $1347(124)$ & $1320(131)$ \\
\hline R-work & $\begin{array}{l}0.1658 \\
(0.1909) \\
\end{array}$ & $\begin{array}{l}0.1898 \\
(0.3161)\end{array}$ \\
\hline R-free & $\begin{array}{l}0.1991 \\
(0.2517)\end{array}$ & $\begin{array}{l}0.2405 \\
(0.3619) \\
\end{array}$ \\
\hline $\begin{array}{l}\text { Number of non- } \\
\text { hydrogen atoms }\end{array}$ & 2340 & 2385 \\
\hline macromolecules & 1950 & 1978 \\
\hline ligands & 24 & 23 \\
\hline solvent & 366 & 384 \\
\hline RMS(bonds) & 0.007 & 0.007 \\
\hline RMS(angles) & 0.81 & 0.82 \\
\hline $\begin{array}{l}\text { Ramachandran } \\
\text { favored (\%) }\end{array}$ & 98.24 & 98.25 \\
\hline $\begin{array}{l}\text { Ramachandran } \\
\text { allowed (\%) }\end{array}$ & 1.76 & 1.75 \\
\hline $\begin{array}{l}\text { Ramachandran } \\
\text { outliers (\%) }\end{array}$ & 0 & 0 \\
\hline $\begin{array}{l}\text { Rotamer outliers } \\
(\%)\end{array}$ & 0 & 0 \\
\hline Clashscore & 2.58 & 3.56 \\
\hline Average B-factor & 14.23 & 13 \\
\hline macromolecules & 11.61 & 10.92 \\
\hline ligands & 63.79 & 12.03 \\
\hline
\end{tabular}


A
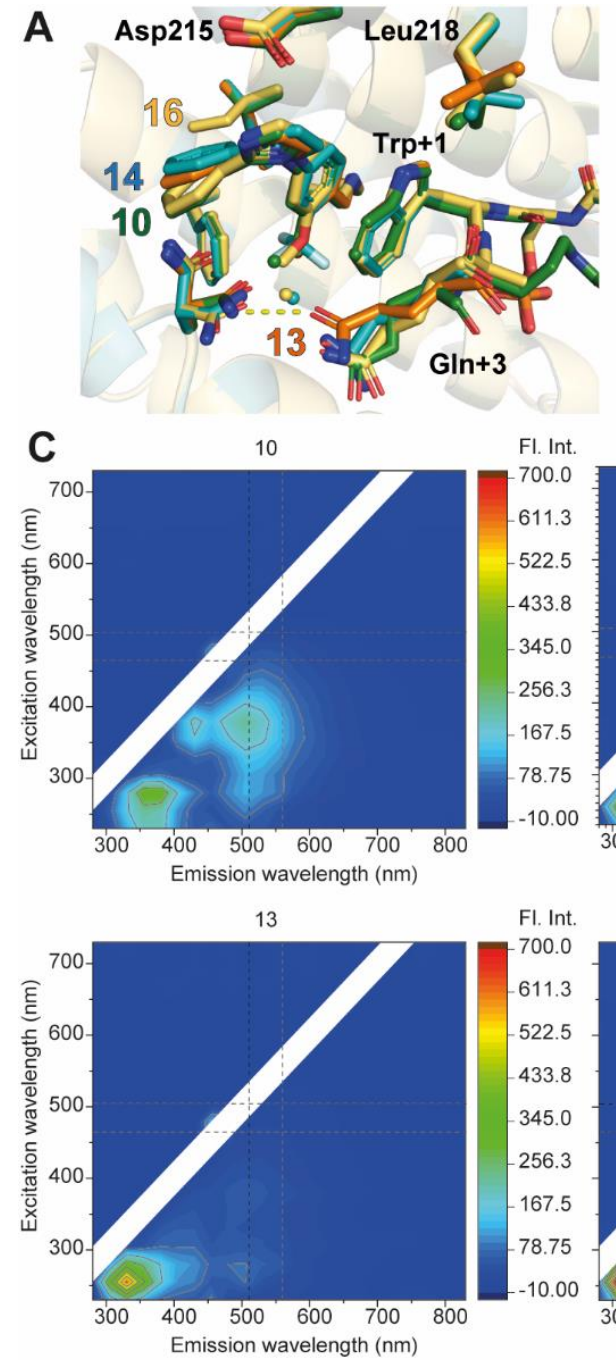

18

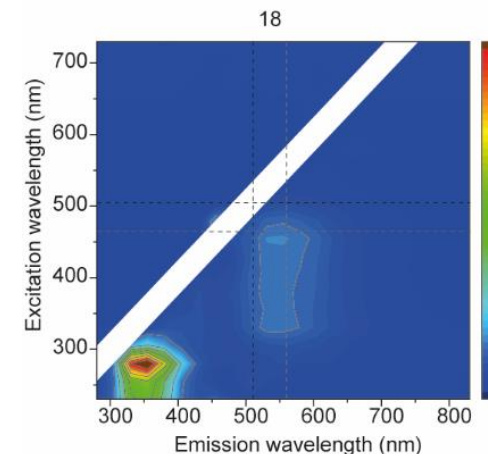

FI. Int.

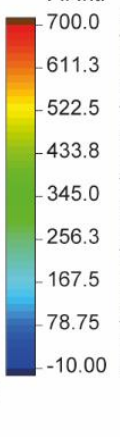

FI. Int.

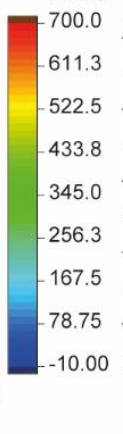

FI. Int

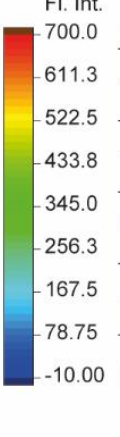

B

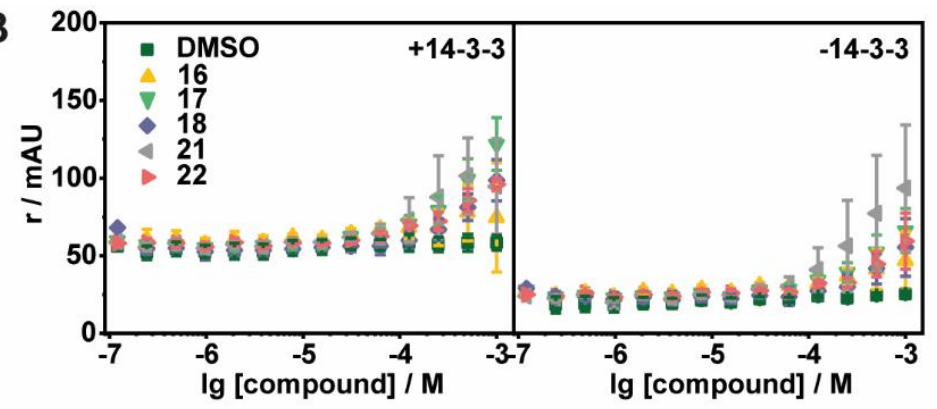

13
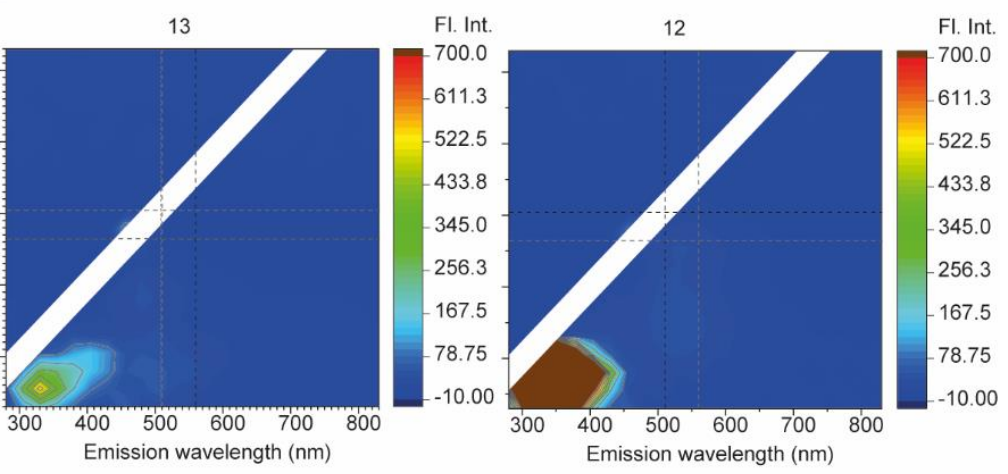

16

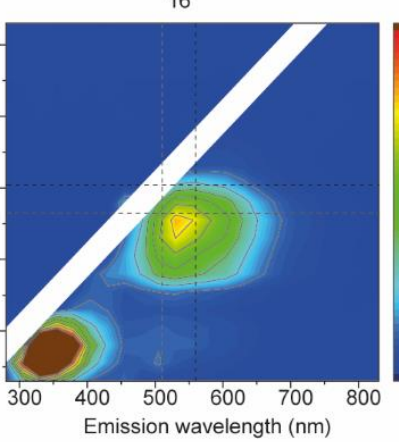

FI. Int.

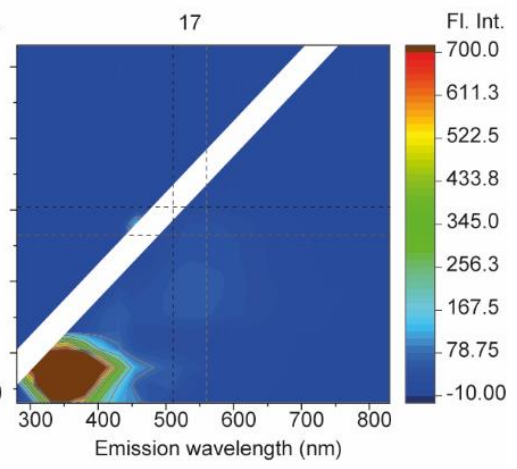

21

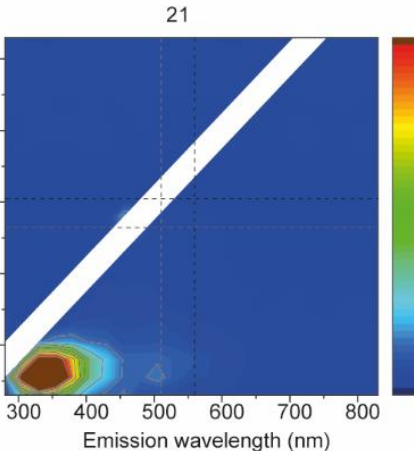

FI. Int.

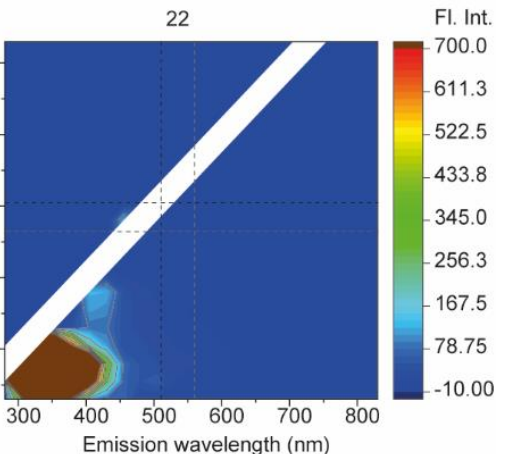

Figure S3: Details of fragments listed in Table 1. (A) Overlay of fragments 10 (green sticks), 13

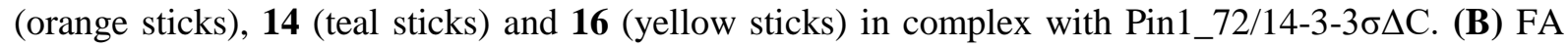
compound titrations show assay interference for 10, 16, 18, 21, 22 as the anisotropy increases in the absence of 14-3-3 $\gamma$ (-14-3-3) to a similar extent as with 14-3-3 $\gamma$ (+14-3-3). (C) Auto-fluorescence of compounds. Excitation/emission spectra of the fragments at a concentration of $1 \mathrm{mM}$. Spectra were

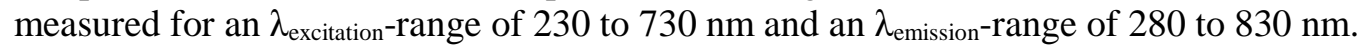



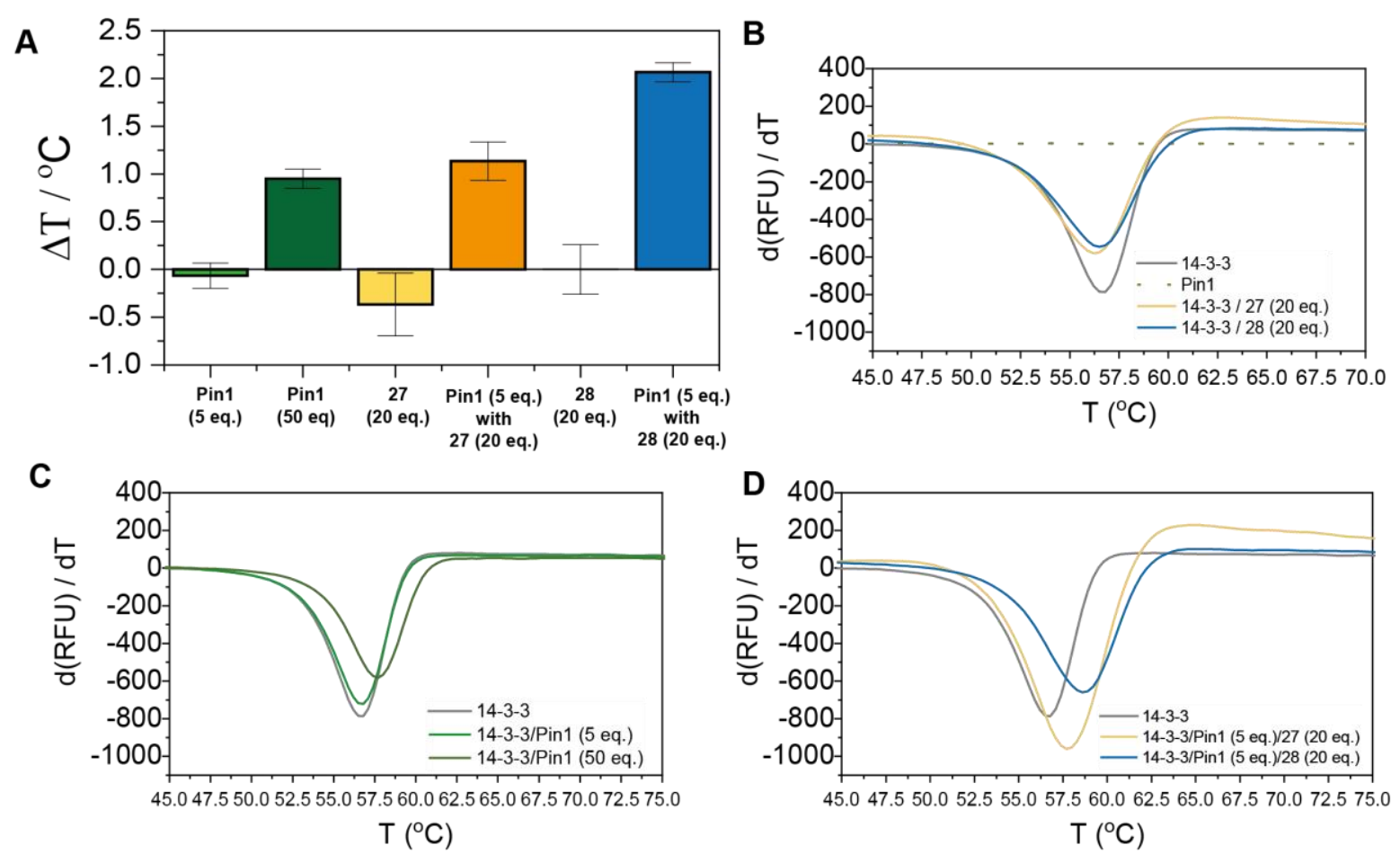

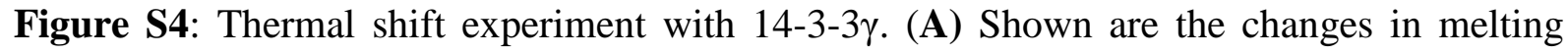
temperature of 14-3-3 $\gamma$ with addition of 5 equivalents (eq.) of Pin1 peptide (light green), 50 eq. Pin 1 peptide (Dark green) and 20 eq. Fragment 27 (yellow). Notably, addition of 20 eq. of 28 resulted in no change in melting temperature. Additionally, change in melting temperature for 14-3-3/Pin1/27 (orange) and14-3-3/Pin1/28 (blue) is also shown. Values are given as the mean average and standard deviations $(n=3)$ of three separate experiments performed using technical

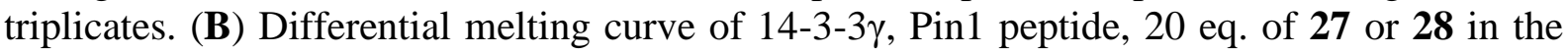
presence of 14-3-3 $\gamma$. (C) Differential melting curve of 14-3-3 $\gamma$, binary 14-3-3/Pin1 complex at 5 and 50 eq of Pin1 peptide. (D) Differential melting curve of 14-3-3 $\gamma$, ternary 14-33/Pin1/fragment complex with 20 eq. fragment 27 or 28. Differential melting curve are given as the mean average of one experiment. 

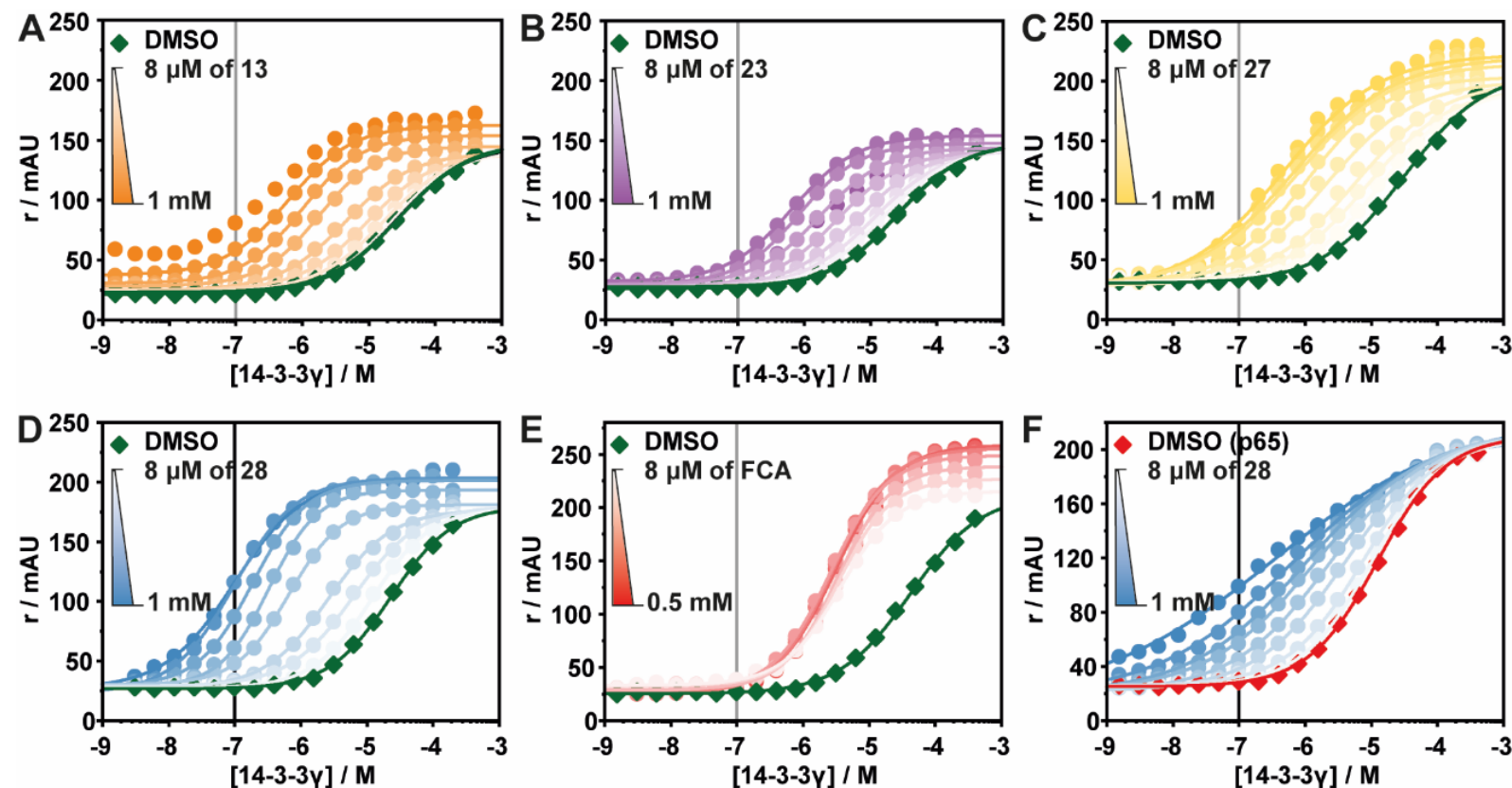

Figure S5: 2D Titrations of fragment 13, 23, 27 and $\mathbf{2 8}$ with Pin1_72 or p65_45 peptide and 14-3-3 $\gamma$. Concentrations of fragment and 14-3-3 as indicated and 100nM Pin1_72 ( $n=1)$. (A) 2D titration of 13 with Pin1_72. (B) 2D titration of 14 with Pin1_72. (C) 2D titration of 27 with Pin1_72. (D) 2D titration of 28 with Pin1_72. (E) 2D titration of FCA with Pin1_72. (F) 2D titration of 28 with p65_45.

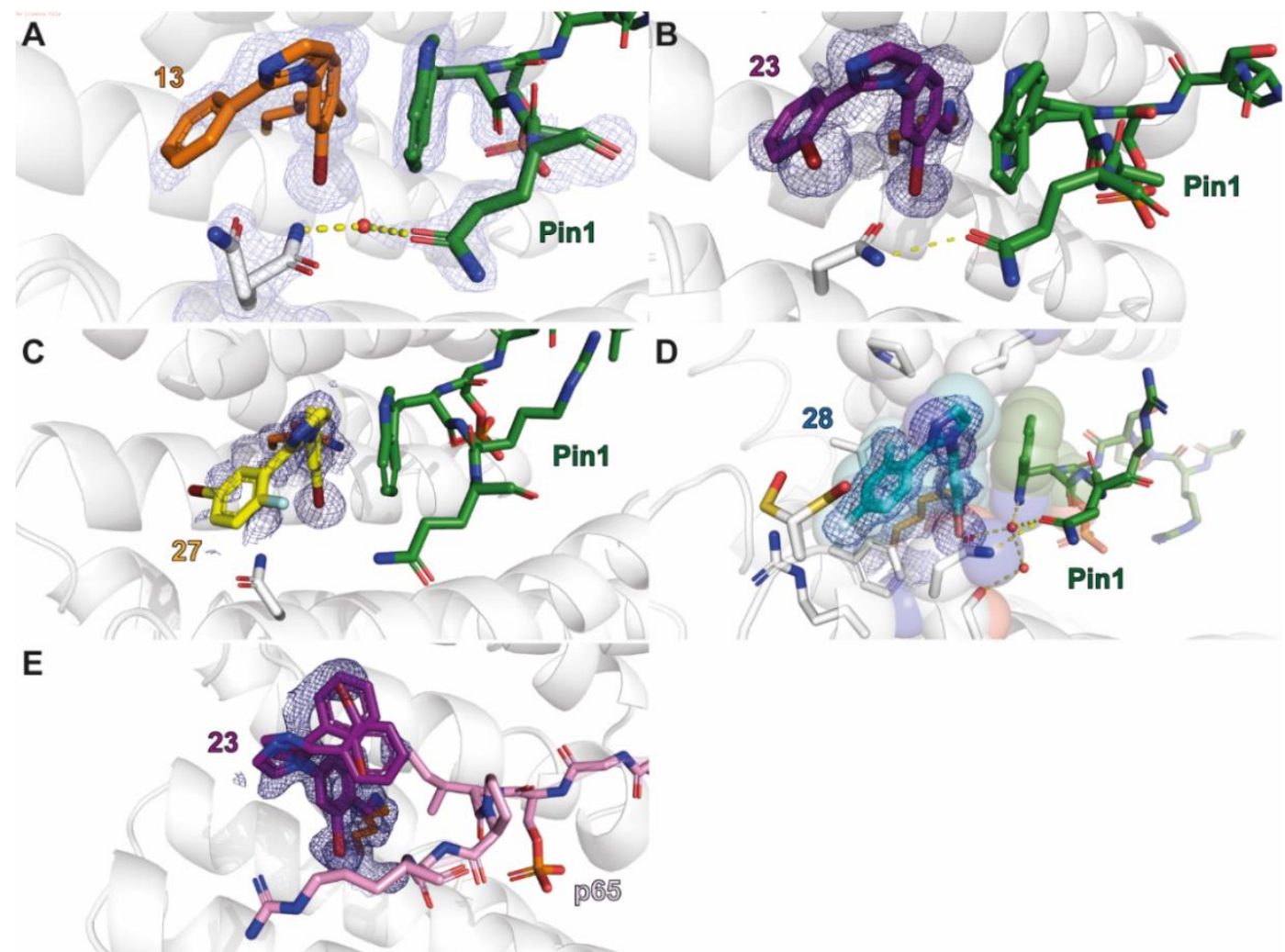

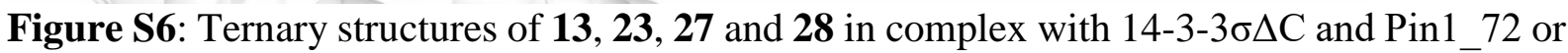
p65. (A) Fragment 13 (orange sticks) with Pin1_72 (green sticks). (B) Fragment 23 (violet sticks) with Pin1_72 (green sticks). (C) Fragment 27 (Cyan sticks) with Pin1_72 (green sticks).

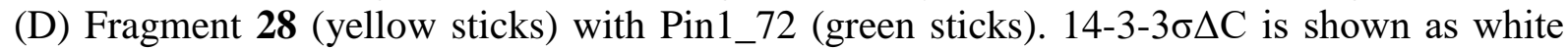
cartoon and sticks; the Pin1_72 is displayed as green cartoon. (E) Fragment 23 (violet sticks) with p65 (rosa sticks). The $2 \mathrm{Fo}-\mathrm{Fc}$ electron density map (blue mesh) is contoured at $1 \sigma$. 
A
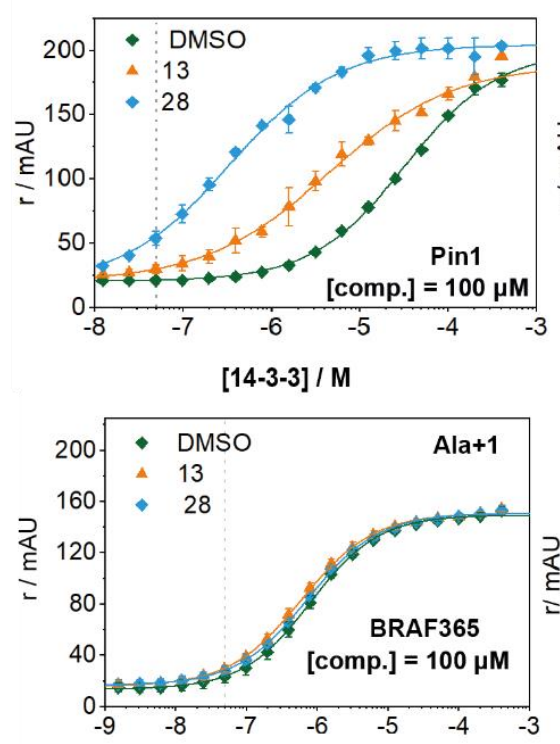

[14-3-3] / M
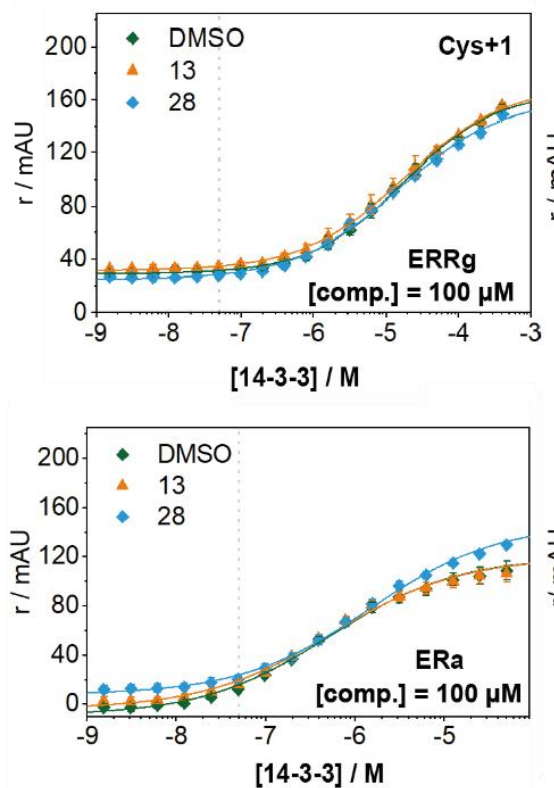

B

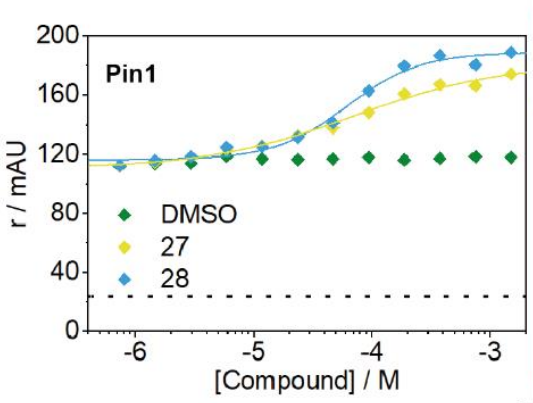

C
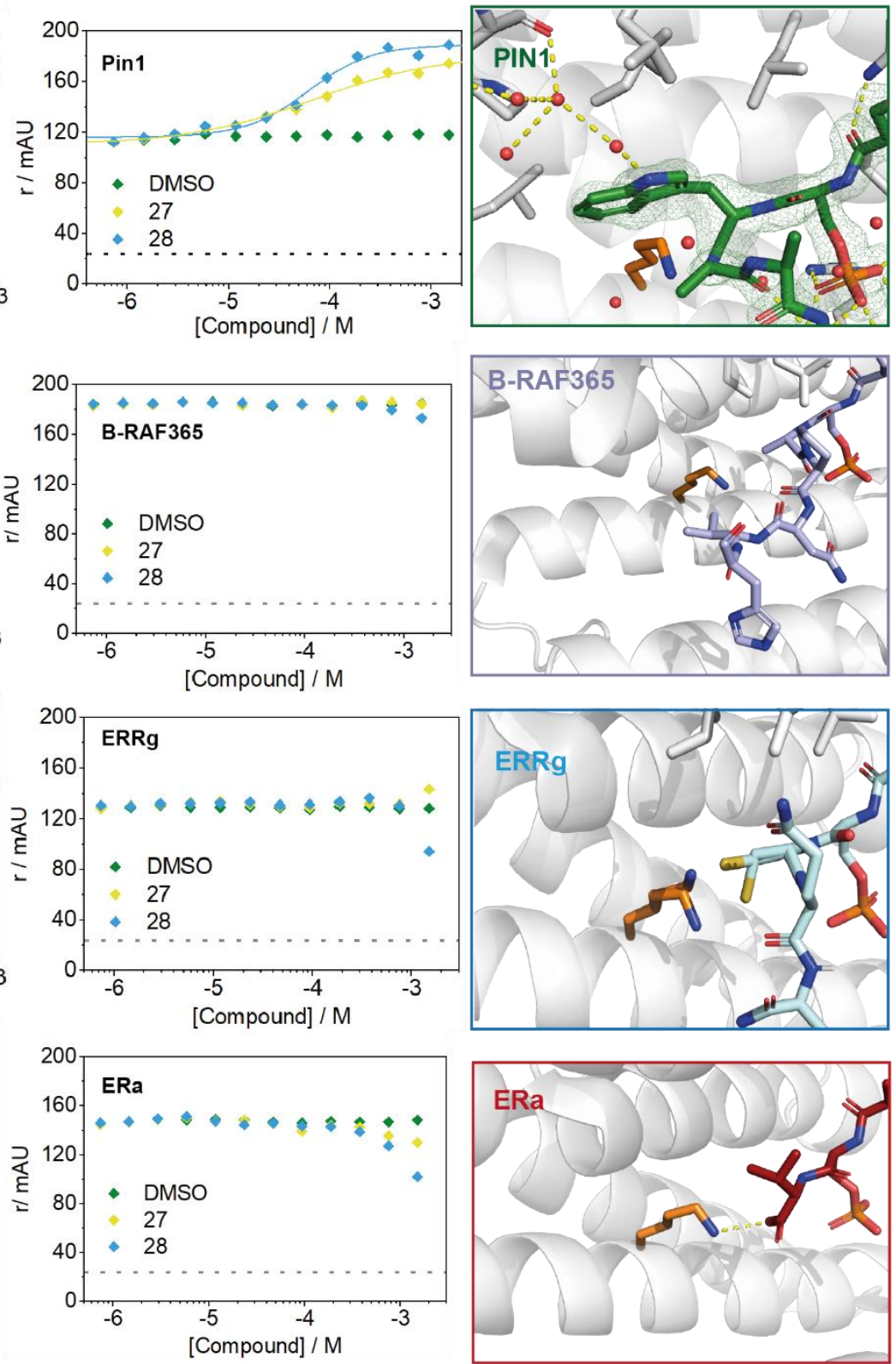

Figure S7: Competition assay. (A) Protein titration of 14-3-3 with $50 \mathrm{nM}$ of Pin1, BRaf pS365, ERR $\gamma$ or ER $\alpha$ and $100 \mu \mathrm{M}$ of 13 or 28. (B) Compound Titration after overnight incubation of 14-3-3 $\gamma$ and 27 or 28, followed by addition of $100 \mathrm{nM}$ of Pin1, BRaf pS365, ERR $\gamma$ or ER $\alpha$. The grey dotted line indicates the anisotropy of 100\% free peptide. (C) Enlarged view of the interface of the binary 14-3-3/partner peptide complex for Pin1, BRaf pS365, ERR $\gamma$ or ER $\alpha$. 
Table S4: Data collection and refinement statistics for the 13 and 23 in complex with p65_45 and

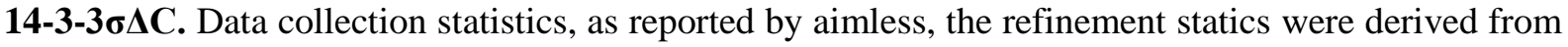
the 'Table1' software of the phenix suite. Values in parenthesis represent the highest resolution shell.

\begin{tabular}{|c|c|c|}
\hline Compound number & 13 & 23 \\
\hline PDB code & 7NQP & 7NSV \\
\hline X-ray source & DESY, Petra III, P11 & DESY, Petra III, P11 \\
\hline \multicolumn{3}{|l|}{ Data Collection } \\
\hline Wavelength & 1.0332 & 1.0332 \\
\hline Resolution range & $66.38-1.24(1.27-1.24)$ & $66.35-1.33$ (1.36-1.33) \\
\hline Space group & C2221 & C2221 \\
\hline \multicolumn{3}{|l|}{ Unit cell } \\
\hline$a, b, c(\AA)$ & 82.396112 .03562 .607 & 82.91112 .1662 .64 \\
\hline$\alpha, \beta, \gamma\left(^{\circ}\right)$ & 909090 & 909090 \\
\hline Unique reflections & $81921(5898)$ & $66729(4896)$ \\
\hline Multiplicity & $12.0(8.1)$ & $9.2(9.1)$ \\
\hline Completeness (\%) & $99.8(97.8)$ & $100(100)$ \\
\hline Mean I/sigma(I) & $11.1(1.0)$ & $9.9(1.1)$ \\
\hline R-merge & $0.102(1.734)$ & $0.103(1.369)$ \\
\hline R-meas & $0.106(1.851)$ & $0.109(1.452)$ \\
\hline R-pim & $0.030(0.630)$ & $0.036(0.479)$ \\
\hline $\mathrm{CC} 1 / 2$ & $0.998(0.636)$ & $0.998(0.722)$ \\
\hline \multicolumn{3}{|l|}{ Refinement } \\
\hline Reflections used in refinement & 81852 (7959) & $66692(6591)$ \\
\hline Reflections used for R-free & $4082(403)$ & 3339 (309) \\
\hline R-work & $0.1946(0.3485)$ & $0.2020(0.3558)$ \\
\hline$R$-free & $0.2161(0.3573)$ & $0.2130(0.3742)$ \\
\hline Number of non-hydrogen atoms & 2209 & 2164 \\
\hline macromolecules & 1913 & 1887 \\
\hline ligands & 20 & 46 \\
\hline solvent & 276 & 231 \\
\hline RMS(bonds) & 0.01 & 0.007 \\
\hline RMS(angles) & 1.13 & 0.92 \\
\hline Ramachandran favored (\%) & 98.66 & 98.17 \\
\hline Ramachandran allowed (\%) & 1.34 & 1.83 \\
\hline Ramachandran outliers (\%) & 0 & 0 \\
\hline Rotamer outliers (\%) & 0.51 & 0 \\
\hline Clashscore & 4.2 & 4.99 \\
\hline Average B-factor & 20.27 & 20.12 \\
\hline macromolecules & 18.32 & 18.33 \\
\hline ligands & 33.3 & 51.15 \\
\hline solvent & 32.79 & 28.57 \\
\hline
\end{tabular}




\section{Experimental Section - Biophysical Assays}

\section{Protein Expression and Purification}

The 14-3-3 proteins were recombinantly expressed in BL21(DE3) cells using pPROEX HTb

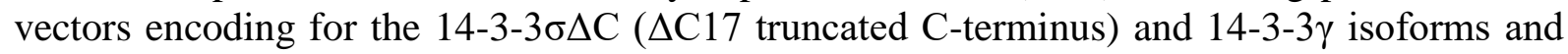
TB medium. At a culture density of $\mathrm{OD}_{600}=0.8-1$, protein expression was initiated with $0.4 \mathrm{mM}$ IPTG for $18 \mathrm{~h}$ at $18^{\circ} \mathrm{C}$. The cells were isolated by centrifugation $(10.000 \mathrm{xg}, 15 \mathrm{~min})$ and resuspended in lysis buffer $(50 \mathrm{mM}$ Tris/ $\mathrm{HCl} \mathrm{pH} 8,300 \mathrm{mM} \mathrm{NaCl}, 12.5 \mathrm{mM}$ imidazole, $2 \mathrm{mM}$ $\beta$-mercaptoethanol). A homogenizer was utilized for cell lysis, followed by centrifugation (40.000 xg, 30min) to clear the lysate. The proteins were purified using standard protocols for Ni-NTA-columns. The proteins were eluted with $250 \mathrm{mM}$ imidazole $(50 \mathrm{mM}$ Tris/ $\mathrm{HCl} \mathrm{pH} 8$, $300 \mathrm{mM} \mathrm{NaCl}, 250 \mathrm{mM}$ imidazole, $2 \mathrm{mM} \beta$-mercaptoethanol) and the full length 14-3-3 $\gamma$ was dialysis against 25mM HEPES $\mathrm{pH} 7.5,100 \mathrm{mM} \mathrm{NaCl}, 10 \mathrm{mM} \mathrm{MgCl}_{2}, 0.5 \mathrm{mM}$ Tris(2carboxyethyl)phosphine) and stored at $-80^{\circ} \mathrm{C}$. The $14-3-3 \sigma \Delta \mathrm{C}$ for crystallography required removal of the His6-tag by TEV protease; the TEV was removed with Ni-NTA-columns. To ensure highest purity, the $14-3-3 \sigma \Delta \mathrm{C}$ was applied to a size exclusion chromatography $(20 \mathrm{mM}$ HEPES pH7.5, $150 \mathrm{mM} \mathrm{NaCl}, 2 \mathrm{mM} \beta$-mercaptoethanol) and stored at $-80^{\circ} \mathrm{C}$.

\section{X-Ray Crystallography}

All binary crystals prepared by mixing $12 \mathrm{mg} / \mathrm{ml} 14-3-3 \sigma \Delta \mathrm{C}$ in a $1: 2$ ratio with acetylated peptide in $20 \mathrm{mM}$ HEPES pH7.5, $2 \mathrm{mM} \mathrm{MgCl}_{2}, 2 \mathrm{mM} \beta$-mercaptoethanol, followed by overnight incubation. Pin1_72/14-3-3 $\sigma \Delta \mathrm{C}$ crystals were grown in a hanging drop set up, whereby the complexation solution was mixed in 1:1 ratio with precipitation buffer $(95 \mathrm{mM}$

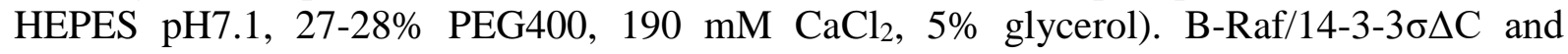
Abl1/14-3-3 $\sigma \Delta \mathrm{C}$ crystals were grown in a sitting drop set up. The complexation solution was mixed in 1:1 ratio with precipitation buffer (95 mM HEPES pH7.5, 27-28\% PEG400, $190 \mathrm{mM}$ $\mathrm{CaCl}_{2}, 5 \%$ glycerol). For AS160/14-3-3 $\sigma \Delta \mathrm{C}$ crystals the complexation solution was mixed in a 1:1 ration with the Wizard Cryo ${ }^{\mathrm{TM}}$ crystallization screen (Rigaku, Bainbridge Island, US), resulting in crystal growth with 40\% (v/v) MPD and $100 \mathrm{mM}$ CHES/ Sodium hydroxide $\mathrm{pH}$ 9.5. All crystals were directly flash-frozen in liquid nitrogen and data acquisition took place at either the P11 beamline of PetraIII (DESY campus, Hamburg, Germany) or i-03/i-24 beamline of the diamond light source (Oxford, UK) or in-house.

Fragment screening was performed by crystal soaking, whereby a final concentration of $10 \mathrm{mM}$ fragment was added to fully grown crystals (final DMSO $\leq 1 \%$ ). The fragment/crystal mixtures incubated for seven days prior to data acquisition at the diamond light source (beamline i03, Oxford, UK), DESY (P11, Hamburg, Germany) or a homesource as indicated. The diffraction data were analyzed with the xia2/DIALS pipeline ${ }^{1}$ and MolRep ${ }^{2,3}$ was used for phasing. For solving the Pin1/14-3-3 and AS160/14-3-3 structures the PDB entry 4JDD served as search model. The search model for fragment soaks was the correlating binary structure (Pin1/14-3-3: 7AOG, p65/14-3-3: 6QHL). For model refinement Coot $^{4}$, Refmac5 ${ }^{5}$ and phenix.refine ${ }^{6}$ were utilized in iterative cycles. The elbow software of the phenix suite ${ }^{6}$ was used for ligand preparation based on fragment SMILES. Figures were generated with PyMOL@ (V2.0.6, Schrodinger LLC).

\section{Fluorescence Anisotropy (FA) Assays}

Dissociation constants of binary complex formation were measured with a 1:1 dilution series of 14-3-3 $\gamma$ in the presence of $50 \mathrm{nM}$ fluorescently labeled peptide (Table S5). Stabilization factors (SF) were measured by a 1:1 dilution series of $14-3-3 \gamma$ in the presence of $50 \mathrm{nM}$ fluorescently labeled peptide and $100 \mu \mathrm{M}$ compound (or as indicated) or DMSO as control,

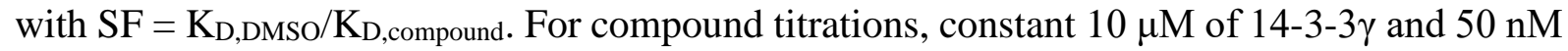


of fluorescently labeled Pin1_72 peptide was used, whereby the compound was titrated in a 1:1 dilution series. All FA assays were measured in FA buffer (10 mM HEPES pH 7.4, $150 \mathrm{mM}$ $\mathrm{NaCl}, 0.1 \%$ Tween20, 1\% BSA) in Corning 384 well plates (black, round bottom, low binding). Plates were incubated overnight prior to anisotropy measurements with the Tecan Infinite 500 plate reader $\left(\lambda_{\text {excitation }}=485 \mathrm{~nm}, \lambda_{\text {emission }}=535 \mathrm{~nm}\right)$.

Table S5: Overview of utilized peptide epitopes. Given are the names as mentioned in the main text, the binding site, the N-terminal modifications with either a fluorophore-linker construct or an acetylation (ace.) for crystallography, the binding sequence and the reference.

\begin{tabular}{|l|l|l|l|l|}
\hline Name & $\begin{array}{l}\text { Binding } \\
\text { Site }\end{array}$ & $\begin{array}{l}\text { N-term. } \\
\text { modification }\end{array}$ & Binding Epitope & $\begin{array}{l}\text { Reference/ } \\
\text { Purchased }\end{array}$ \\
\hline Pin1_71 & pS71 & FITC-Ahx & LVKHSQSRRP pS SWRQEK & Genscript \\
\hline Pin1_72 & pS72 & $\begin{array}{l}\text { FITC-Ahx/ } \\
\text { ace. }\end{array}$ & LVKHSQSRRPS pS WRQEK & Genscript \\
\hline p65 & pS45pS281 & FITC- $\beta$ Ala & EGRSAG pS IPGRRSGSGGGSGPSDREL pS EPMEFQ & 7 \\
\hline p65_45 & pS45 & ace. & EGRSAG pS IPGRRS & 7 \\
\hline B-Raf & pS729 & FITC-Ahx & IHRSA pS EPSLN & Genscript \\
\hline B-Raf & pS365 & FITC-Ahx & RDRSS pS APNVH & Genscript \\
\hline C-Raf & pT259 & FITC- $\beta$ Ala & SQRQRST pS TPNVH & 8 \\
\hline AS160 & pT642 & $\begin{array}{l}\text { FITC-Ahx/ } \\
\text { ace. }\end{array}$ & RRRAH pT FSHPP & Genscript \\
\hline Abl1 & pT735 & FITC-Ahx & EWRSV pT LPRDL & Genscript \\
\hline CFTR & pS753pS568 & FITC- $\beta$ Ala & AILPRI pS VISTGPTLQARRRQ pS VLNLMT & 9 \\
\hline Raptor & pS792 & FITC-Ahx & MRRAS pS YSSLN & Genscript \\
\hline ER $\alpha$ & pT594 & FITC-O1Pen & AEGFPA pT V-COOH & 8 \\
\hline Mypt1 & pS472 & FITC- $\beta$ Ala & GVTRSA pS SPRLSS & $\begin{array}{l}\text { Synthesized } \\
\text { in-house' }\end{array}$ \\
\hline ERR $\gamma$ & pS179 & FITC-Ahx & KRRRK pS CQA & 10 \\
\hline TBC1D & pS237 & FITC-Ahx & MRKSF pS QPGLR & Genscript \\
\hline
\end{tabular}

\section{Excitation/Emission Scans}

Excitation/Emission profiles of fragments were measured at a final concentraion of $1 \mathrm{mM}$ in PBS buffer (137 mM NaCl, $2.7 \mathrm{mM} \mathrm{KCl,} 10 \mathrm{mM} \mathrm{Na}_{2} \mathrm{HPO}_{4}, 1.8 \mathrm{mM} \mathrm{KH}_{2} \mathrm{PO}_{4}$ ). Measurements were performed with a Tecan Safire 2 plate reader $\left(\lambda_{\text {excitation }}=230-730 \mathrm{~nm} ; \lambda_{\text {emission }}=280-830\right.$ $\mathrm{nm}$; step size: $25 \mathrm{~nm}$; gain: 60; lagtime: $0 \mu \mathrm{s}$ ) in a Corning 384-well plate (black, round bottom, low volume, low binding).

\section{Experimental Section - Chemistry}

\section{General materials}

All reactions were prepared using AR or HPLC grade solvents without further purification. All reagents were purchase from Fluorochem, ABCR, Ak Scientific or Simga-Adrich and were used without further purification unless stated. Microwave reactions were performed using a Biotage Initiator Plus equipped with a handling robot. Solvents were removed in vacuo using a Büchi rotary evaporator and a diaphragm pump. DMF and $\mathrm{CH}_{2} \mathrm{Cl}_{2}$ were dried and purified by means of a MBRAUN Solvent Purification System (MB-SPS-800). All other solvents used were of chromatography or analytical grade and supplied by Biosolve or Sigma-Aldrich. TLC was carried out on aluminum-backed silica (Merck silica gel 60 F254) plates supplied by Merck. Visualization of the plates was achieved using an ultraviolet lamp $\left(\lambda_{\max }=254 \mathrm{~nm}\right), 2,4-$ $\mathrm{DNP}, \mathrm{KMnO}_{4}$, anisaldehyde, bromine or ninhydrin. Column chromatography was either 
performed manually using silica gel (60-63 um particle size), automated Grace Reveleris X2 or Biotage Isolera chromatograph with prepacked silica columns supplied by Buchi/Grace (40 $\mu \mathrm{m}$ particle size). LC-MS analysis was carried out with a system comprising a Phenomex kinetex ${ }^{\circledR} 2.6 \mu \mathrm{m}$ EVO C18 $50 \times 2.1 \mathrm{~mm}$ column using ultrapure water with $0.1 \%$ formic acid (FA) and acetonitrile with $0.1 \% \mathrm{FA}$, in general with using a gradient of $5-100 \% \mathrm{MeCN}$ in water $(+0.1 \% \mathrm{HCOOH})$ over $10 \mathrm{~min}$, connected to a Thermo Fisher LCQ Fleet Ion Trap Mass Spectrometer. The purity of the samples was assessed using a PDA and MS. Unless otherwise stated all final compounds were $\geq 95 \%$ pure as judged by HPLC. GCMS analysis was performed on a Phenomenex Zebron ZB-5MS $30 \mathrm{~m} \times 0.25 \mathrm{~mm} \times 0.25 \mathrm{~mm}$ column with a gradient of 80 ${ }^{\circ} \mathrm{C}$ for $1 \mathrm{~min}$ to $300{ }^{\circ} \mathrm{C}$ for $1 \mathrm{~min}$ with a rate of $30^{\circ} \mathrm{C} / \mathrm{min}$ in helium gas connected to a GCMSQP2010 Plus Quadrupole Mass Spectrometer. High resolution mass spectra (HRMS) were recorded using a Waters ACQUITY UPLC I-Class LC system coupled to a Xevo G2 Quadrupole Time of Flight (Q-tof) mass spectrometer equipped with a Phenomex kinetex ${ }^{\circledR} 2.6$ $\mu \mathrm{m}$ EVO C18 $100 \times 2.1 \mathrm{~mm}$ column. Proton $\left({ }^{1} \mathrm{H}\right)$ and carbon $\left({ }^{13} \mathrm{C}\right) \mathrm{NMR}$ spectral data were collected on a $400 \mathrm{MHz}$ Bruker Cryomagnet or $400 \mathrm{MHz}$ Varian Gemini. Chemical shifts $(\delta)$ are quoted in parts per million (ppm) and referenced to the residual solvent peak. Coupling constants $(J)$ are quoted in Hertz $(\mathrm{Hz})$ and splitting patterns reported in an abbreviated manner: app. (apparent), s (singlet), d (doublet), t (triplet), q (quartet), and m (multiplet). Assignments were made with the aid of 2D COSY, HMQC, and HMBC experiments.

\section{Synthetic Procedures and Characterization}

\section{General Procedure 1}

To a microwave reaction tube was added 4-fluorobenzaldehyde derivative (1 eq), imidazole derivative $(1.1 \mathrm{eq})$ and potassium carbonate $(1.5 \mathrm{eq})$ in $2 \mathrm{~mL}$ of DMF. The reaction mixture was subject to microwave irradiation at $120{ }^{\circ} \mathrm{C}$ for $15 \mathrm{~min}$. To the resulting reaction mixture was added water $(50 \mathrm{~mL})$ and was extracted with ethyl acetate $(2 \times 50 \mathrm{~mL})$. The organic layers were combined, washed with water $(3 \times 100 \mathrm{~mL})$ and brine $(100 \mathrm{~mL})$. The organic layer was then separated, dried over sodium sulphate and concentrated under vacuum. The resulting crude residue was then subject silica column chromatography (gradient; hexane/EtOAc) to afford the titled compound.

\section{General Procedure 2}

To a microwave reaction tube was added 4-fluorobenzaldehyde derivative $(1 \mathrm{eq})$, imidazole derivative $(1.1 \mathrm{eq})$ and potassium carbonate $(1.5 \mathrm{eq})$ in $2 \mathrm{~mL}$ of DMF. The reaction mixture was subject to microwave irradiation at $120{ }^{\circ} \mathrm{C}$ for $15 \mathrm{~min}$. To the resulting reaction mixture was added water $(10 \mathrm{~mL})$ and the reaction mixture was subject to 2 min of ultra-sonication. The resulting precipitate was then filtered under vacuum, washed with water $(2 \times 3 \mathrm{~mL})$ and dried under vacuum to afford the titled compound

\section{Compound Characterization}

\section{3-bromo-4-(1H-imidazol-1-yl)benzaldehyde (1)}

Fragment 1 was synthesized according to general synthesis procedure 2 using 3-bromo-4fluorobenzaldehyde (203 mg, $1.00 \mathrm{mmol}), \mathrm{K}_{2} \mathrm{CO}_{3}(207 \mathrm{mg}, 1.50 \mathrm{mmol})$ and imidazole $(75$ $\mathrm{mg}, 1.10 \mathrm{mmol}$ ) to afford an amorphous cream solid (120 mg, 48\%); LRMS (ESI+) $250 \mathrm{~m} / \mathrm{z}$ $(\mathrm{M}+\mathrm{H})$; HRMS (ESI) calcd for $\mathrm{C}_{10} \mathrm{H}_{8} \mathrm{BrN}_{2} \mathrm{O}(\mathrm{M}+\mathrm{H}), 250.9815$; found 250.9810; ${ }^{1} \mathrm{H}$ NMR $\left(400 \mathrm{MHz}, \mathrm{DMSO}-d_{6}\right) \delta 10.1(\mathrm{~s}, 1 \mathrm{H}), 8.4(\mathrm{~d}, J=1.7 \mathrm{~Hz}, 1 \mathrm{H}), 8.0(\mathrm{dd}, J=8.1,1.8 \mathrm{~Hz}, 1 \mathrm{H})$, $8.0(\mathrm{~s}, 1 \mathrm{H}), 7.7(\mathrm{~d}, J=8.0 \mathrm{~Hz}, 1 \mathrm{H}), 7.5(\mathrm{~s}, 0 \mathrm{H}), 7.1(\mathrm{~s}, 1 \mathrm{H}) ;{ }^{13} \mathrm{C}$ NMR $(101 \mathrm{MHz}, \mathrm{DMSO}) \delta$ $191.8,141.3,138.1,137.5,135.2,129.7,129.6,129.5,121.3,120.0$. 


\section{2-chloro-4-(1H-imidazol-1-yl)benzaldehyde (2)}

Fragment 2 was synthesized according to general synthesis procedure 1 using 2-chloro-4fluorobenzaldehyde $(159 \mathrm{mg}, 1.00 \mathrm{mmol}), \mathrm{K}_{2} \mathrm{CO}_{3}(207 \mathrm{mg}, 1.50 \mathrm{mmol})$ and imidazole $(75 \mathrm{mg}$, $1.10 \mathrm{mmol}$ ) to afford an amorphous cream solid (38 mg, 18\%); LRMS (ESI+) $207 \mathrm{~m} / \mathrm{z}(\mathrm{M}+\mathrm{H})$; HRMS (ESI) calcd for $\mathrm{CH}_{8} \mathrm{ClN}_{2} \mathrm{O}(\mathrm{M}+\mathrm{H}), 207.0325$; found 207.0323; ${ }^{1} \mathrm{H}$ NMR $(400 \mathrm{MHz}$, Acetone-d6) $\delta 10.42(\mathrm{~s}, 1 \mathrm{H}), 8.34(\mathrm{~s}, 1 \mathrm{H}), 8.03(\mathrm{~d}, J=8.5 \mathrm{~Hz}, 1 \mathrm{H}), 7.94(\mathrm{~d}, J=2.1 \mathrm{~Hz}, 1 \mathrm{H})$, $7.89-7.76(\mathrm{~m}, 2 \mathrm{H}), 7.17(\mathrm{~s}, 1 \mathrm{H}) ;{ }^{13} \mathrm{C} \mathrm{NMR}(100 \mathrm{MHz}$, Acetone) $\delta 188.7,143.2,139.4,136.6$, $132.0,131.9,131.4,122.5,119.9,118.4$.

\section{2-bromo-4-(1H-imidazol-1-yl)benzaldehyde (3)}

Fragment 3 was synthesized according to general synthesis procedure 2 using 2-bromo-4fluorobenzaldehyde (100 mg, $0.49 \mathrm{mmol}), \mathrm{K}_{2} \mathrm{CO}_{3}(74.9 \mathrm{mg}, 0.54 \mathrm{mmol})$ and imidazole (36.9 $\mathrm{mg}, 0.54 \mathrm{mmol}$ ) to afford an amorphous cream solid (91 mg, 74\%); LRMS (ESI+) $250 \mathrm{~m} / \mathrm{z}$ $(\mathrm{M}+\mathrm{H})$; HRMS (ESI) calcd for $\mathrm{C}_{10} \mathrm{H}_{8} \mathrm{BrN}_{2} \mathrm{O}(\mathrm{M}+\mathrm{H}), 250.9815$; found $250.9813 ;{ }^{1} \mathrm{H}$ NMR (400 MHz, Acetone) $\delta 8.34(\mathrm{~s}, 1 \mathrm{H}), 8.11(\mathrm{~d}, J=2.2 \mathrm{~Hz}, 1 \mathrm{H}), 8.01(\mathrm{~d}, J=8.5 \mathrm{~Hz}, 1 \mathrm{H}), 7.88(\mathrm{dd}, J=$ 8.5, 2.1 Hz, 1H), $7.81(\mathrm{~s}, 1 \mathrm{H}), 7.17(\mathrm{~s}, 1 \mathrm{H}), 2.05(\mathrm{p}, J=2.2 \mathrm{~Hz}, 3 \mathrm{H}) ;{ }^{13} \mathrm{C}$ NMR $(101 \mathrm{MHz}$, Acetone) $\delta 190.7,143.2,136.6,132.5,132.2,132.0,128.2,125.7,120.5,118.4$.

\section{4-(4-methyl-1H-imidazol-1-yl)benzaldehyde (4)}

Fragment 4 was synthesized according to general synthesis procedure 1 using 4fluorobenzaldehyde (200 mg, $1.61 \mathrm{mmol}), \mathrm{K}_{2} \mathrm{CO}_{3}(245 \mathrm{mg}, 1.77 \mathrm{mmol})$ and 4-methylimidazole (146 mg, $1.77 \mathrm{mmol})$. The reaction mixture was diluted with water $(50 \mathrm{~mL})$ and was extracted with ethylacetate $(2 \times 50 \mathrm{~mL})$. The resulting mixture was washed with sodium chloride solution $(100 \mathrm{~mL})$. The material was absorbed to silica and subject to automated column chromatography $(0-100 \%$ Hexane:EtOAc) to afford the titled compound as cream solid (70 $\mathrm{mg}, 21.3 \%$ ); LRMS (ESI+) $\mathrm{m} / z 187(\mathrm{M}+\mathrm{H})$; HRMS (ESI) calcd for $\mathrm{C}_{11} \mathrm{H}_{11} \mathrm{~N}_{2} \mathrm{O}(\mathrm{M}+\mathrm{H})$, 187.0871; found 187.0869; ${ }^{1} \mathrm{H}$ NMR (400 MHz, Acetone) $\delta 10.05(\mathrm{~s}, 1 \mathrm{H}), 8.15(\mathrm{~s}, 1 \mathrm{H}), 8.05$ $(\mathrm{d}, J=8.7 \mathrm{~Hz}, 2 \mathrm{H}), 7.82(\mathrm{~d}, J=8.6 \mathrm{~Hz}, 2 \mathrm{H}), 7.44(\mathrm{~s}, 1 \mathrm{H}), 2.21(\mathrm{~s}, 3 \mathrm{H}) .{ }^{13} \mathrm{C}$ NMR $(101 \mathrm{MHz}$, Acetone) $\delta 191.7,142.7,140.9,135.6,135.5,132.2(2 \mathrm{C}), 120.9$ (2C), 114.6, 13.9

NB: structural isomer [4-(3-methyl-1H-imidazol-1-yl)benzaldehyde] observed as a $7.4 \%$ impurity (based on proton NMR).

\section{4-(4-(trifluoromethyl)-1H-imidazol-1-yl)benzaldehyde (6)}

Fragment 6 was synthesized according to general synthesis procedure 1 using 4fluorobenzaldehyde (200 mg, $1.61 \mathrm{mmol}), \mathrm{K}_{2} \mathrm{CO}_{3}(245 \mathrm{mg}, 1.17 \mathrm{mmol})$ and 4(trifluoromethyl)-1H-imidazol (241 mg, $1.17 \mathrm{mmol}$ ) to afford an amorphous cream solid (109 mg, 39\%); LRMS (ESI+) $241 \mathrm{~m} / z(\mathrm{M}+\mathrm{H})$; HRMS (ESI) calcd for $\mathrm{C}_{11} \mathrm{H}_{8} \mathrm{~F}_{3} \mathrm{~N}_{2} \mathrm{O}(\mathrm{M}+\mathrm{H})$, 241.0586; found 241.0589; ${ }^{1} \mathrm{H}$ NMR (400 MHz, Acetone-d6) $\delta 10.11(\mathrm{~s}, 1 \mathrm{H}), 8.42(\mathrm{~s}, 1 \mathrm{H}), 8.31$ $(\mathrm{s}, 1 \mathrm{H}), 8.13(\mathrm{~d}, J=8.6 \mathrm{~Hz}, 2 \mathrm{H}), 7.98(\mathrm{~d}, J=8.6 \mathrm{~Hz}, 2 \mathrm{H}) ;{ }^{13} \mathrm{C}$ NMR $(101 \mathrm{MHz}$, Acetone) $\delta$ 191.8, 141.6, 138.1, 136.8, 134.1, (q, $J=38.5 \mathrm{~Hz}), 132.1(2 \mathrm{C}), 122.8$, (q, $J=266.3), 122.5$ (2C), $119.5(\mathrm{q}, J=4.0 \mathrm{~Hz})$.

\section{4-(1H-benzo[d]imidazol-1-yl)benzaldehyde (7)}

Fragment 7 was synthesized according to general synthesis procedure 2 using using 4fluorobenzaldehyde (100 mg, $0.81 \mathrm{mmol}), \mathrm{K}_{2} \mathrm{CO}_{3}(123 \mathrm{mg}, 0.89 \mathrm{mmol})$ and benzimidazole (105 $\mathrm{mg}, 0.89 \mathrm{mmol}$ ) to afford the titled compound as a brown solid (45 $\mathrm{mg}, 25 \%$ ); LRMS $\left(\right.$ ESI+) $m / z 223(\mathrm{M}+\mathrm{H})$; HRMS (ESI) calcd for $\mathrm{C}_{14} \mathrm{H}_{11} \mathrm{~N}_{2} \mathrm{O}(\mathrm{M}+\mathrm{H}), 223.0871$; found 223.0860; ${ }^{1} \mathrm{H}$ NMR $(400 \mathrm{MHz}$, Chloroform-d) $\delta 10.11(\mathrm{~s}, 1 \mathrm{H}), 8.19(\mathrm{~s}, 1 \mathrm{H}), 8.12(\mathrm{~d}, J=8.5 \mathrm{~Hz}, 2 \mathrm{H}), 7.90$ $(\mathrm{dt}, J=7.1,3.6 \mathrm{~Hz}, 1 \mathrm{H}), 7.74(\mathrm{~d}, J=8.4 \mathrm{~Hz}, 2 \mathrm{H}), 7.62(\mathrm{dt}, J=6.7,3.5 \mathrm{~Hz}, 1 \mathrm{H}), 7.43-7.34$ 
$(\mathrm{m}, 2 \mathrm{H}) ;{ }^{13} \mathrm{C}$ NMR $(100 \mathrm{MHz}, \mathrm{CDCl} 3) \delta 190.8,144.5,141.9,141.5,135.4,133.1(2 \mathrm{C}), 131.8$, $124.4,123.9(2 \mathrm{C}), 123.6,121.2,110.6$.

\section{1-(4-formylphenyl)-1H-imidazole-2-carboxylic acid (8)}

Fragment 2 was synthesized according to general synthesis procedure 2 using 2-chloro-4fluorobenzaldehyde $(124 \mathrm{mg}, 1.00 \mathrm{mmol}), \mathrm{K}_{2} \mathrm{CO}_{3}(207 \mathrm{mg}, 1.50 \mathrm{mmol})$ and imidazole $(123$ $\mathrm{mg}, 1.10 \mathrm{mmol})$ to afford the titled compound as an off-white amorphous solid $(18 \mathrm{mg}, 8 \%)$; LRMS (ESI+) $217 \mathrm{~m} / \mathrm{z}(\mathrm{M}+\mathrm{H})$; HRMS (ESI) calcd for $\mathrm{C}_{11} \mathrm{H}_{8} \mathrm{~N}_{2} \mathrm{O}_{3}(\mathrm{M}+\mathrm{H}), 217.0608$; found 217.0612; ${ }^{1} \mathrm{H}$ NMR (400 MHz, Acetone- $\left.d_{6}\right) \delta 10.08(\mathrm{~s}, 1 \mathrm{H}), 8.27(\mathrm{~s}, 1 \mathrm{H}), 8.09$ (d, $J=8.4 \mathrm{~Hz}$, $2 \mathrm{H}), 7.89(\mathrm{~d}, J=8.4 \mathrm{~Hz}, 2 \mathrm{H}), 7.17(\mathrm{~s}, 1 \mathrm{H}) ;{ }^{13} \mathrm{C}$ NMR $(100 \mathrm{MHz}$, Acetone) $\delta 192.7,143.6$, 137.4, 136.8, 133.1 (2C), 132.7, 122.4 (2C), 119.3.

\section{4-(2-phenyl-1H-imidazol-1-yl)benzaldehyde (9)}

Fragment 9 was synthesized according to general synthesis procedure 2 using 4fluorobenzaldehyde (100 $\mathrm{mg}, 0.81 \mathrm{mmol}), \mathrm{K}_{2} \mathrm{CO}_{3}(122.5 \mathrm{mg}, 0.89 \mathrm{mmol})$ and 2phenylimidazole $(127.8 \mathrm{mg}, 0.89 \mathrm{mmol})$ to afford the titled compound as anorphous yellow oil (0.8 mg, 0.4\%); LRMS (ESI+) m/z $249(\mathrm{M}+\mathrm{H})$; HRMS (ESI) calcd for $\mathrm{C}_{16} \mathrm{H}_{13} \mathrm{~N}_{2} \mathrm{O}(\mathrm{M}+\mathrm{H})$, 248.1028; found 249.1024; ${ }^{1} \mathrm{H}$ NMR (400 MHz, DMSO-d6) $\delta 10.04(\mathrm{~s}, 1 \mathrm{H}), 7.98$ (d, $J=8.4$ $\mathrm{Hz}, 2 \mathrm{H}), 7.61(\mathrm{~d}, J=1.3 \mathrm{~Hz}, 1 \mathrm{H}), 7.58-7.46(\mathrm{~m}, 2 \mathrm{H}), 7.46-7.27(\mathrm{~m}, 5 \mathrm{H}), 7.24(\mathrm{~d}, J=1.3$ $\mathrm{Hz}, 1 \mathrm{H}) .{ }^{13} \mathrm{C}$ NMR (101 MHz, DMSO) $\delta 192.7,146.3,143.2,135.7,131.2(2 \mathrm{C}), 130.6,129.7$, 129.0, $128.90(2 \mathrm{C}), 128.85(2 \mathrm{C}), 126.9(2 \mathrm{C}), 123.9$.

\section{2-chloro-4-(2-phenyl-1H-imidazol-1-yl)benzaldehyde (10)}

Fragment 10 was synthesized according to general synthesis procedure 2 using 3-chloro-4fluorobenzaldehyde (100 mg, $0.81 \mathrm{mmol}), \mathrm{K}_{2} \mathrm{CO}_{3}(116 \mathrm{mg}, 0.84 \mathrm{mmol})$ and 2-phenylimidazole (90.1 $\mathrm{mg}, 0.63 \mathrm{mmol}$ ) to afford the titled compound as a brown solid (45 $\mathrm{mg}, 20 \%$ ); LRMS (ESI+) $\mathrm{m} / z, 283(\mathrm{M}+\mathrm{H})$; HRMS (ESI) calcd for $\mathrm{C}_{16} \mathrm{H}_{12} \mathrm{ClN}_{2} \mathrm{O}(\mathrm{M}+\mathrm{H}), 283.0638$; found 283.0639; ${ }^{1} \mathrm{H}$ NMR $(400 \mathrm{MHz}$, Acetone) $\delta 10.41(\mathrm{~s}, 1 \mathrm{H}), 7.92(\mathrm{~d}, J=8.3 \mathrm{~Hz}, 1 \mathrm{H}), 7.57(\mathrm{~d}, J=$ $2.0 \mathrm{~Hz}, 1 \mathrm{H}), 7.51(\mathrm{~d}, J=1.4 \mathrm{~Hz}, 1 \mathrm{H}), 7.42(\mathrm{dd}, J=7.5,2.1 \mathrm{~Hz}, 2 \mathrm{H}), 7.39(\mathrm{~d}, J=2.0 \mathrm{~Hz}, 1 \mathrm{H})$, $7.38-7.29(\mathrm{~m}, 3 \mathrm{H}), 7.21(\mathrm{~d}, J=1.4 \mathrm{~Hz}, 1 \mathrm{H}) .{ }^{13} \mathrm{C}$ NMR $(101 \mathrm{MHz}$, Acetone) $\delta 189.0,147.3$, $144.8,138.5,132.5,131.4,131.2,130.5,129.7(2 \mathrm{C}), 129.5,129.2(2 \mathrm{C}), 128.4,126.0,123.6$.

\section{3-chloro-4-(2-phenyl-1H-imidazol-1-yl)benzaldehyde (11)}

Fragment 11 was synthesized according to general synthesis procedure 2 using 3-chloro-4fluorobenzaldehyde (159 mg, $1.00 \mathrm{mmol}), \mathrm{K}_{2} \mathrm{CO}_{3}(207 \mathrm{mg}, 1.50 \mathrm{mmol})$ and 2-phenylimidazole (159 mg, $1.10 \mathrm{mmol}$ ) to afford an amorphous cream solid (31 mg, 11\%); LRMS (ESI+) $\mathrm{m} / \mathrm{z}$ $283(\mathrm{M}+\mathrm{H})$; HRMS (ESI) calcd for $\mathrm{C}_{16} \mathrm{H}_{12} \mathrm{ClN}_{2} \mathrm{O}(\mathrm{M}+\mathrm{H}), 283.0638$; found 283.0647; ${ }^{1} \mathrm{H}$ NMR $\left(400 \mathrm{MHz}\right.$, Acetone- $\left.d_{6}\right) \delta 10.12(\mathrm{~s}, 1 \mathrm{H}), 8.12(\mathrm{~d}, J=1.7 \mathrm{~Hz}, 1 \mathrm{H}), 8.04(\mathrm{dd}, J=8.0,1.7 \mathrm{~Hz}$, $1 \mathrm{H}), 7.77(\mathrm{~d}, J=8.1 \mathrm{~Hz}, 1 \mathrm{H}), 7.39(\mathrm{dd}, J=7.4,2.0 \mathrm{~Hz}, 2 \mathrm{H}), 7.35(\mathrm{~d}, J=1.3 \mathrm{~Hz}, 1 \mathrm{H}), 7.31-$ $7.21(\mathrm{~m}, 4 \mathrm{H}) ;{ }^{13} \mathrm{C}$ NMR $(100 \mathrm{MHz}$, Acetone) $\delta 191.2,147.8,142.1,138.9,133.4,132.0,131.61$, $131.59,130.3,129.7,129.3,129.2(2 \mathrm{C}), 128.5$ (2C), 123.8 .

\section{3-bromo-4-(2-phenyl-1H-imidazol-1-yl)benzaldehyde (12)}

Fragment 12 was synthesized according to general synthesis procedure 2 using 3-bromo-4fluorobenzaldehyde (100 mg, $0.49 \mathrm{mmol}), \mathrm{K}_{2} \mathrm{CO}_{3}(75 \mathrm{mg}, 0.54 \mathrm{mmol})$ and 2-phenylimidazole (78 $\mathrm{mg}, 0.54 \mathrm{mmol})$ to afford the titled compound as an amorphous brown oil $(9.7 \mathrm{mg}, 6 \%)$; LRMS (ESI+) $m / z, 327(\mathrm{M}+\mathrm{H})$; HRMS (ESI) calcd for $\mathrm{C}_{16} \mathrm{H}_{12} \mathrm{BrN}_{2} \mathrm{O}(\mathrm{M}+\mathrm{H}), 327.0133$; found 327.0139; ${ }^{1} \mathrm{H}$ NMR $\left(400 \mathrm{MHz}, \mathrm{CDCl}_{3}\right) \delta 10.44(\mathrm{~s}, 1 \mathrm{H}), 9.35(\mathrm{~d}, J=8.6 \mathrm{~Hz}, 1 \mathrm{H}), 8.00(\mathrm{~d}, J=$ $7.5 \mathrm{~Hz}, 1 \mathrm{H}), 7.76(\mathrm{t}, J=7.6 \mathrm{~Hz}, 1 \mathrm{H}), 7.70-7.57(\mathrm{~m}, 1 \mathrm{H}), 7.49(\mathrm{~d}, J=7.5 \mathrm{~Hz}, 1 \mathrm{H}), 7.30(\mathrm{~d}, J$ 
$=7.6 \mathrm{~Hz}, 2 \mathrm{H}), 7.23-7.01(\mathrm{~m}, 3 \mathrm{H}) .{ }^{13} \mathrm{C} \mathrm{NMR}\left(101 \mathrm{MHz}, \mathrm{CDCl}_{3}\right) \delta 192.7,135.7,132.0,131.7$, $130.4,130.1,128.8,128.7,128.5$ (2C), 127.9 (2C), 125.5, 124.7, 123.4.

\section{2-bromo-4-(2-phenyl-1H-imidazol-1-yl)benzaldehyde (13)}

Fragment 13 was synthesized according to general synthesis procedure 1 using 2-bromo-4fluorobenzaldehyde (100 mg, $0.49 \mathrm{mmol}), \mathrm{K}_{2} \mathrm{CO}_{3}(75 \mathrm{mg}, 0.54 \mathrm{mmol})$ and 2-phenylimidazole (78.1 mg, $0.54 \mathrm{mmol}$ to afford the titled compound as a brown solid (64 mg, 40\%); LRMS (ESI+) $\mathrm{m} / z 327(\mathrm{M}+\mathrm{H})$; HRMS (ESI) calcd for $\mathrm{C}_{16} \mathrm{H}_{12} \mathrm{BrN}_{2} \mathrm{O}(\mathrm{M}+\mathrm{H}), 327.0133$; found 327.0130; ${ }^{1} \mathrm{H}$ NMR $\left(400 \mathrm{MHz}\right.$, Acetone- $\left.d_{6}\right) \delta 10.32(\mathrm{~s}, 1 \mathrm{H}), 7.92(\mathrm{~d}, J=8.3 \mathrm{~Hz}, 1 \mathrm{H}), 7.76(\mathrm{~d}$, $1 \mathrm{H}), 7.53(\mathrm{~s}, 1 \mathrm{H}), 7.48-7.31(\mathrm{~m}, 6 \mathrm{H}), 7.22(\mathrm{~s}, 1 \mathrm{H}) .{ }^{13} \mathrm{C} \mathrm{NMR}\left(100 \mathrm{MHz}, \mathrm{CDCl}_{3}\right) \delta 190.5$, $147.1,143.9,132.7,130.9,130.4,130.3,129.7,129.3,129.0$ (2C), 128.7 (2C), 127.5, 125.2, 122.2 .

\section{4-(2-phenyl-1H-imidazol-1-yl)-2-(trifluoromethyl)benzaldehyde (14)}

Fragment 14 was synthesized according to general synthesis procedure 2 using 4-Fluoro-2(trifluoromethyl)benzaldehyde (100 mg, $0.52 \mathrm{mmol}), \mathrm{K}_{2} \mathrm{CO}_{3}(79 \mathrm{mg}, 0.57 \mathrm{mmol})$ and 2phenylimidazole $(82.6 \mathrm{mg}, 0.57 \mathrm{mmol})$ to afford the titled compound as a brown solid $(75 \mathrm{mg}$, 46\%); LRMS (ESI+) $m / z 317(\mathrm{M}+\mathrm{H})$; HRMS (ESI) calcd for $\mathrm{C}_{16} \mathrm{H}_{12} \mathrm{BrN}_{2} \mathrm{O}(\mathrm{M}+\mathrm{H}), 317.0902$; found 317.0906. ${ }^{1} \mathrm{H}$ NMR (400 MHz, Acetone) $\delta 10.36(\mathrm{~d}, J=2.3 \mathrm{~Hz}, 1 \mathrm{H}), 8.19(\mathrm{~d}, J=8.3$ $\mathrm{Hz}, 1 \mathrm{H}), 7.88(\mathrm{~s}, 1 \mathrm{H}), 7.78(\mathrm{~d}, J=8.3 \mathrm{~Hz}, 1 \mathrm{H}), 7.63(\mathrm{~s}, 1 \mathrm{H}), 7.51-7.31(\mathrm{~m}, 6 \mathrm{H}), 7.27(\mathrm{~s}, 1 \mathrm{H})$; ${ }^{13} \mathrm{C}$ NMR $\left(100 \mathrm{MHz}\right.$, Acetone- $\left.d_{6}\right) \delta 189.4(\mathrm{q}, J=2.1 \mathrm{~Hz}), 148.3,144.6,134.4(\mathrm{~d}, J=1.5 \mathrm{~Hz})$, $133.1,132.7(\mathrm{~d}, J=33.1 \mathrm{~Hz}), 132.2$, 131.6, 130.7 (2C), 130.5, 130.1 (2C), 125.5 (q, $J=6.0$ $\mathrm{Hz}), 124.5$.

\section{4-(2-phenyl-1H-imidazol-1-yl)-3-(trifluoromethyl)benzaldehyde (15)}

Fragment 15 was synthesized according to general synthesis procedure 2 using 4-Fluoro-3(trifluoromethyl)benzaldehyde (100 mg, $0.52 \mathrm{mmol}), \mathrm{K}_{2} \mathrm{CO}_{3}(96 \mathrm{mg}, 0.69 \mathrm{mmol})$ and 2phenylimidazole $(75 \mathrm{mg}, 0.52 \mathrm{mmol})$ to afford the titled compound as a brown solid $(9 \mathrm{mg}$, 5.4\%); LRMS (ESI+) $\mathrm{m} / z 317(\mathrm{M}+\mathrm{H})$; HRMS (ESI) calcd for $\mathrm{C}_{17} \mathrm{H}_{12} \mathrm{~F}_{3} \mathrm{~N}_{2} \mathrm{O}(\mathrm{M}+\mathrm{H}), 317.0902$; found 317.0921; ${ }^{1} \mathrm{H}$ NMR (400 MHz, DMSO-d6) $\delta 10.17(\mathrm{~s}, 1 \mathrm{H}), 8.46(\mathrm{~d}, J=1.8 \mathrm{~Hz}, 1 \mathrm{H})$, $8.28(\mathrm{dd}, J=8.1,1.8 \mathrm{~Hz}, 1 \mathrm{H}), 7.81(\mathrm{~d}, J=8.1 \mathrm{~Hz}, 1 \mathrm{H}), 7.51$ (brs, $1 \mathrm{H}), 7.29-7.24(\mathrm{~m}, 6 \mathrm{H})$; ${ }^{13} \mathrm{C}$ NMR $\left(101 \mathrm{MHz}, \mathrm{DMSO}-d_{6}\right) \delta 192.0,147.2,140.9(\mathrm{~d}, J=1.7 \mathrm{~Hz}$, *quartet not completely resolved), 137.1, 134.4, 132.9, 130.2, 129.2, 128.9 (2C), 127.9 (2C), 127.2 (q, $J=31.2 \mathrm{~Hz}$ ), $125.4,122.9$ (d, $J=274.2 \mathrm{~Hz}$, *quartet not completely resolved).

\section{2-methoxy-4-(2-phenyl-1H-imidazol-1-yl)benzaldehyde (16)}

Fragment 16 was synthesized according to general synthesis procedure 2 using 2-methoxy-4fluorobenzaldehyde (100 mg, $0.65 \mathrm{mmol}), \mathrm{K}_{2} \mathrm{CO}_{3}(89.7 \mathrm{mg}, 0.65 \mathrm{mmol})$ and 2-phenylimidazole (62.4 $\mathrm{mg}, 0.43 \mathrm{mmol})$ to afford the titled compound as a brown solid (22.9 $\mathrm{mg}, 19 \%)$; LRMS (ESI+) $\mathrm{m} / z \quad 279(\mathrm{M}+\mathrm{H})$; HRMS (ESI) calcd for $\mathrm{C}_{17} \mathrm{H}_{15} \mathrm{~N}_{2} \mathrm{O}_{2}(\mathrm{M}+\mathrm{H}), 279.1134$; found 279.1133; ${ }^{1} \mathrm{H}$ NMR (400 MHz, $\left.\mathrm{CDCl}_{3}\right) \delta 10.40(\mathrm{~s}, 1 \mathrm{H}), 7.84(\mathrm{~d}, J=8.3 \mathrm{~Hz}, 1 \mathrm{H}), 7.39$ (dd, $J$ $=7.6,2.0 \mathrm{~Hz}, 1 \mathrm{H}), 7.33-7.24(\mathrm{~m}, 3 \mathrm{H}), 7.21(\mathrm{~s}, 1 \mathrm{H}), 6.90(\mathrm{dd}, J=8.2,1.2 \mathrm{~Hz}, 1 \mathrm{H}), 6.72(\mathrm{~d}, J$ $=1.9 \mathrm{~Hz}, 1 \mathrm{H}), 3.70(\mathrm{~s}, 2 \mathrm{H}) .{ }^{13} \mathrm{C} \mathrm{NMR}\left(100 \mathrm{MHz}, \mathrm{CDCl}_{3}\right) \delta 207.1,188.6,162.2,146.9,144.6$, $130.1,123.0,129.8,128.9$ (2C), 128.5 (2C), 124.0, 122.2, 117.6, 109.5, 56.0.

\section{3-methoxy-4-(2-phenyl-1H-imidazol-1-yl)benzaldehyde (17)}

Fragment 17 was synthesized according to general synthesis procedure 1 using 3-methoxy-4fluorobenzaldehyde (100 mg, $0.65 \mathrm{mmol}), \mathrm{K}_{2} \mathrm{CO}_{3}(99 \mathrm{mg}, 0.71 \mathrm{mmol})$ and 2-phenylimidazole (103 mg, $0.71 \mathrm{mmol}$ ) to afford the titled compound as a brown solid (7 mg, 10\%); LRMS (ESI+) 
$m / z, 279(\mathrm{M}+\mathrm{H})$; HRMS (ESI) calcd for $\mathrm{C}_{17} \mathrm{H}_{15} \mathrm{~N}_{2} \mathrm{O}_{2}(\mathrm{M}+\mathrm{H}), 279.1134$; found 279.1144; ${ }^{1} \mathrm{H}$ NMR (400 MHz, Acetone) $\delta 10.07(\mathrm{~s}, 1 \mathrm{H}), 7.65(\mathrm{~d}, J=6.6 \mathrm{~Hz}, 2 \mathrm{H}), 7.54(\mathrm{~d}, J=8.2 \mathrm{~Hz}, 1 \mathrm{H})$, $7.43-7.36(\mathrm{~m}, 2 \mathrm{H}), 7.33-7.22(\mathrm{~m}, 4 \mathrm{H}), 7.20(\mathrm{~s}, 1 \mathrm{H}), 3.70(\mathrm{~s}, 3 \mathrm{H}) .{ }^{13} \mathrm{C} \mathrm{NMR}(100 \mathrm{MHz}$, Acetone) $\delta$ 192.1, 155.7, 147.9, 138.9, 133.6, 132.1, 129.9, 129.5, 129.1, 128.9 (2C), 128.4 (2C), 124.1, 124.0, 112.8, 56.4.

\section{3-methyl-4-(2-phenyl-1H-imidazol-1-yl)benzaldehyde (18)}

Fragment 18 was synthesized according to general synthesis procedure 1 using 4-Fluoro-3methylbenzaldehyde (100 mg, $0.72 \mathrm{mmol}), \mathrm{K}_{2} \mathrm{CO}_{3}(133.4 \mathrm{mg}, 0.97 \mathrm{mmol})$ and 2phenylimidazole $(72.4 \mathrm{mg}, 0.72 \mathrm{mmol})$ to afford the titled compound as an amorphous brown oil (12 mg, 6.6\%); LRMS (ESI+) $263 \mathrm{~m} / z(\mathrm{M}+\mathrm{H})$; HRMS (ESI) calcd for $\mathrm{C}_{17} \mathrm{H}_{15} \mathrm{~N}_{2} \mathrm{O}(\mathrm{M}+\mathrm{H})$, 263.1179; found 263.1185; ${ }^{1} \mathrm{H}$ NMR $(400 \mathrm{MHz}$, Acetone) $\delta 10.09(\mathrm{~s}, 1 \mathrm{H}), 7.91(\mathrm{~d}, J=7.1$ $\mathrm{Hz}, 2 \mathrm{H}), 7.56(\mathrm{~d}, J=8.7 \mathrm{~Hz}, 1 \mathrm{H}), 7.39$ (dd, $J=7.8,1.9 \mathrm{~Hz}, 2 \mathrm{H}), 7.32-7.20(\mathrm{~m}, 4 \mathrm{H}), 2.03$ (s, $3 \mathrm{H}) .{ }^{13} \mathrm{C}$ NMR (101 MHz, Acetone) $\delta 192.3,143.9,137.8,137.2,133.1,131.8,130.3,129.6$, 129.2, 129.1 (2C), 129.0, 128.4(2C), 123.6, 17.5.

\section{2-hydroxy-4-(2-phenyl-1H-imidazol-1-yl)benzaldehyde (19)}

Boron tribromide (1 M in DCM, $5 \mathrm{~mL}$ ) was added dropwise to a solution of 2-methoxy-4-(2phenyl-1H-imidazol-1-yl)benzaldehyde $(\mathbf{1 6}, 30 \mathrm{mg}, 0.11 \mathrm{mmol})$ in anhydrous DCM (3 $\mathrm{mL})$. The reaction was stirred at $\mathrm{rt}$ overnight after addition under an argon atmosphere. The reaction was quenched using ice water, followed by additional $5 \mathrm{M}$ hydrochloride solution until the $\mathrm{pH}$ reached 1 . The product was extracted using ethylacetate $(2 \times 50 \mathrm{~mL})$. The resulting organic layer was washed with saturated sodium chloride solution $(100 \mathrm{~mL})$. The crude residue was absorbed to silica and subject to column chromatography (0-20\% EtOAc:methanol) to afford the titled compound as a yellow solid (5 mg, 17\%); LRMS (ESI+) $\mathrm{m} / \mathrm{z} 265(\mathrm{M}+\mathrm{H})$; HRMS (ESI) calcd for $\mathrm{C}_{16} \mathrm{H}_{13} \mathrm{~N}_{2} \mathrm{O}_{2}(\mathrm{M}+\mathrm{H}), 265.0977$; found 265.0974; ${ }^{1} \mathrm{H}$ NMR (400 MHz, Acetone-d6) $\delta 10.09$ $(\mathrm{s}, 1 \mathrm{H}), 7.92-7.75(\mathrm{~m}, 1 \mathrm{H}), 7.56-7.40(\mathrm{~m}, 3 \mathrm{H}), 7.39-7.26(\mathrm{~m}, 3 \mathrm{H}), 7.20(\mathrm{~d}, \mathrm{~J}=1.3 \mathrm{~Hz}, 1 \mathrm{H})$, $7.05-6.81(\mathrm{~m}, 2 \mathrm{H}) .13 \mathrm{C}$ NMR (101 MHz, Acetone) $\delta$ 198.0, 187.1, 136.5, 132.6, 131.3, 130.4, 130.3 (2C), 130.02, 130.01 (2C), 124.5, 122.4, 122.1, 119.2, 115.8.

\section{4-(2-phenyl-1H-imidazol-1-yl)-3-(trifluoromethoxy)benzaldehyde (20)}

Fragment 20 was synthesized according to general synthesis procedure 1 using 4-Fluoro-3(trifluoromethoxy)benzaldehyde (100 mg, $0.48 \mathrm{mmol}), \mathrm{K}_{2} \mathrm{CO}_{3}(66 \mathrm{mg}, 0.48 \mathrm{mmol})$ and 2 phenylimidazole (46 mg, $0.32 \mathrm{mmol}$ ) to afford the titled compound as an amorphous brown oil (64 mg, 60\%); LRMS (ESI+) $m / z 333\left(\mathrm{M}+\mathrm{H}\right.$ ); HRMS (ESI) calcd for $\mathrm{C}_{17} \mathrm{H}_{12} \mathrm{~F}_{3} \mathrm{~N}_{2} \mathrm{O}_{2}(\mathrm{M}+\mathrm{H}$ ), 333.0851; found 333.0837; ${ }^{1} \mathrm{H}$ NMR (400 MHz, Acetone- $\left.d_{6}\right) \delta 10.15(\mathrm{~s}, 1 \mathrm{H}), 8.10(\mathrm{~d}, J=8.1$ $\mathrm{Hz}, 1 \mathrm{H}), 8.00(\mathrm{~s}, 1 \mathrm{H}), 7.83(\mathrm{~d}, J=8.1 \mathrm{~Hz}, 1 \mathrm{H}), 7.42(\mathrm{~s}, 1 \mathrm{H}), 7.38(\mathrm{~d}, J=5.7 \mathrm{~Hz}, 2 \mathrm{H}), 7.33-$ $7.28(\mathrm{~m}, 4 \mathrm{H}) ;{ }^{13} \mathrm{C}$ NMR $\left(101 \mathrm{MHz}\right.$, Acetone- $\left.d_{6}\right) \delta 191.1,148.1,144.8(\mathrm{q}, J=1.6 \mathrm{~Hz}), 138.7$, $136.8,131.4,131.4,130.4,129.9,129.4,129.1(2 \mathrm{C}), 128.6(2 \mathrm{C}), 124.0,122.4,121.0$ (q, $J=$ $259.2 \mathrm{~Hz})$.

\section{3-phenoxy-4-(2-phenyl-1H-imidazol-1-yl)benzaldehyde (21)}

Fragment 21 was synthesized according to general synthesis procedure 1 using 3-phenoxy-4fluorobenzaldehyde (100 mg, $0.46 \mathrm{mmol}), \mathrm{K}_{2} \mathrm{CO}_{3}(64 \mathrm{mg}, 0.46 \mathrm{mmol})$ and 2-phenylimidazole (44.5 mg, $0.31 \mathrm{mmol}$ to afford the titled compound as an amorphous brown oil (17.5 mg, 17\%); LRMS (ESI+) $m / z 341(\mathrm{M}+\mathrm{H})$; HRMS (ESI) calcd for $\mathrm{C}_{22} \mathrm{H}_{17} \mathrm{~N}_{2} \mathrm{O}_{2}(\mathrm{M}+\mathrm{H})$, 341.1290; found 341.1291; ${ }^{1} \mathrm{H}$ NMR (400 MHz, Acetone- $\left.d_{6}\right) \delta 10.00(\mathrm{~s}, 1 \mathrm{H}), 7.79(\mathrm{dd}, J=21.9,8.0 \mathrm{~Hz}, 2 \mathrm{H})$, $7.45(\mathrm{~d}, J=7.4 \mathrm{~Hz}, 2 \mathrm{H}), 7.39(\mathrm{~s}, 1 \mathrm{H}), 7.36-7.27(\mathrm{~m}, 6 \mathrm{H}), 7.21-7.14(\mathrm{~m}, 2 \mathrm{H}), 6.66(\mathrm{~d}, J=$ $8.0 \mathrm{~Hz}, 2 \mathrm{H}) ;{ }^{13} \mathrm{C}$ NMR $(101 \mathrm{MHz}$, Acetone) $\delta 191.7,155.5,154.1,148.1,138.6,134.8,132.3$, $131.1(2 \mathrm{C}), 130.5,130.0,129.2,129.1$ (2C), $128.6(2 \mathrm{C}), 125.8,125.7,124.0,120.6(2 \mathrm{C}), 117.8$. 


\section{4-(2-phenyl-1H-imidazol-1-yl)-1-naphthaldehyde (22)}

Fragment 22 was synthesized according to general synthesis procedure 1 using 4-fluoro-1naphtaldehyde $(100 \mathrm{mg}, 0.57 \mathrm{mmol}), \mathrm{K}_{2} \mathrm{CO}_{3}(87 \mathrm{mg}, 0.63 \mathrm{mmol})$ and 2-phenylimidazole (91 $\mathrm{mg}, 0.63 \mathrm{mmol}$ to afford the titled compound as a yellow solid (44 mg, 26\%); LRMS (ESI+) $\mathrm{m} / \mathrm{z} 299(\mathrm{M}+\mathrm{H})$; HRMS (ESI) calcd for $\mathrm{C}_{20} \mathrm{H}_{15} \mathrm{~N}_{2} \mathrm{O}(\mathrm{M}+\mathrm{H}), 299.1184$; found 299.1183 ; ${ }^{1} \mathrm{H}$ NMR $\left(400 \mathrm{MHz}\right.$, Acetone- $\left.d_{6}\right) \delta 10.52(\mathrm{~s}, 1 \mathrm{H}), 9.35(\mathrm{~d}, J=8.6 \mathrm{~Hz}, 1 \mathrm{H}), 8.29(\mathrm{~d}, J=7.5 \mathrm{~Hz}$, $1 \mathrm{H}), 7.84-7.77(\mathrm{~m}, 2 \mathrm{H}), 7.66(\mathrm{t}, J=7.7 \mathrm{~Hz}, 1 \mathrm{H}), 7.52-7.44(\mathrm{~m}, 2 \mathrm{H}), 7.38-7.31(\mathrm{~m}, 3 \mathrm{H})$, $7.23-7.09$ (m, 3H); ${ }^{13} \mathrm{C}$ NMR (100 MHz, Acetone) $\delta 193.9,148.4,141.7,136.8,133.0,132.2$, 131.4, 131.3, 130.6, 130.1, 129.3, 129.2, 129.0 (2C), 128.4 (2C), 126.0, 125.9, 125.3, 124.0,

\section{2-bromo-4-(2-(2-bromophenyl)-1H-imidazol-1-yl)benzaldehyde (23)}

Fragment 23 was synthesized according to general synthesis procedure 2 using 3-bromo-4fluorobenzaldehyde (120 mg, $0.6 \mathrm{mmol}), \mathrm{K}_{2} \mathrm{CO}_{3}(80 \mathrm{mg}, 0.6 \mathrm{mmol})$ and 2-(2-Bromophenyl)1H-imidazole (90 mg, $0.4 \mathrm{mmol}$ ) to afford an amorphous off white solid (94 mg, 58\%); LRMS (ESI+) $m / z \quad 407\left(\mathrm{M}+\mathrm{H}, 100 \%, \mathrm{Br}^{79}, \mathrm{Br}^{81}\right)$; HRMS (ESI) calcd for $\mathrm{C}_{16} \mathrm{H}_{11} \mathrm{Br}_{2} \mathrm{~N}_{2} \mathrm{O}(\mathrm{M}+\mathrm{H})$, 404.9238; found 404.9237; ${ }^{1} \mathrm{H}$ NMR $\left(400 \mathrm{MHz}\right.$, Acetone- $\left.d_{6}\right) \delta 10.25(\mathrm{~s}, 1 \mathrm{H}), 7.84(\mathrm{~d}, J=8.4$ $\mathrm{Hz}, 1 \mathrm{H}), 7.67(\mathrm{~s}, 1 \mathrm{H}), 7.65-7.59(\mathrm{~m}, 5 \mathrm{H}), 7.52(\mathrm{t}, J=7.5 \mathrm{~Hz}, 2 \mathrm{H}), 7.43(\mathrm{t}, J=7.7 \mathrm{~Hz}, 2 \mathrm{H})$, $7.37(\mathrm{~d}, J=8.3 \mathrm{~Hz}, 2 \mathrm{H}), 7.26(\mathrm{~s}, 1 \mathrm{H}) ; 13 \mathrm{C}$ NMR (100 MHz, Acetone) $\delta$ 190.8, 146.2, 144.0, 134.0, 133.70, 133.67, 133.1, 132.2, 131.3, 130.5, 130.3, 128.7, 126.9, 124.9, 124.5, 121.9.

\section{2-bromo-4-(2-(4-bromophenyl)-1H-imidazol-1-yl)benzaldehyde (24)}

Fragment 24 was synthesized according to general synthesis procedure 2 using 3-bromo-4fluorobenzaldehyde (300 mg, $1.5 \mathrm{mmol}), \mathrm{K}_{2} \mathrm{CO}_{3}(210 \mathrm{mg}, 1.5 \mathrm{mmol})$ and 2-(4-Bromophenyl)1H-imidazole $(220 \mathrm{mg}, 1.0 \mathrm{mmol})$ to afford an amorphous cream solid (19 mg, 5\%); LRMS (ESI+) $m / z, 407\left(\mathrm{M}+\mathrm{H}, 100 \%, \mathrm{Br}^{79}, \mathrm{Br}^{81}\right)$; HRMS (ESI) calcd for $\mathrm{C}_{16} \mathrm{H}_{11} \mathrm{Br}_{2} \mathrm{~N}_{2} \mathrm{O}(\mathrm{M}+\mathrm{H})$, 404.9238; found 404.9229; ${ }^{1} \mathrm{H}$ NMR (400 MHz, Acetone-d6) $\delta 10.33$ (s, 1H), 7.95 (d, J = 8.3 $\mathrm{Hz}, 1 \mathrm{H}), 7.82(\mathrm{~d}, \mathrm{~J}=2.0 \mathrm{~Hz}, 1 \mathrm{H}), 7.54(\mathrm{~d}, \mathrm{~J}=8.9 \mathrm{~Hz}, 3 \mathrm{H}), 7.47(\mathrm{dd}, \mathrm{J}=8.4,2.0 \mathrm{~Hz}, 1 \mathrm{H}), 7.38$ $(\mathrm{d}, \mathrm{J}=8.5 \mathrm{~Hz}, 2 \mathrm{H}), 7.23(\mathrm{~s}, 1 \mathrm{H}) ; 13 \mathrm{C}$ NMR $(100 \mathrm{MHz}$, Acetone) $\delta 190.9,146.2,144.5,133.8$, 132.4 (2C), 131.63, 131.60, 131.4 (2C), 130.7, 130.5, 127.3, 126.6, 124.1, 123.3.

\section{2-bromo-4-(2-(4-hydroxyphenyl)-1H-imidazol-1-yl)benzaldehyde (25)}

Fragment 25 was synthesized according to general synthesis procedure 1 using 3-bromo-4fluorobenzaldehyde (300 mg, $1.5 \mathrm{mmol}), \mathrm{K}_{2} \mathrm{CO}_{3}(210 \mathrm{mg}, 1.5 \mathrm{mmol})$ and 4-(1H-Imidazol-2yl)phenol (160 mg, $1.0 \mathrm{mmol}$ ) to afford an amorphous cream solid (66 mg, 19\%); LRMS (ESI+) $m / z 343(\mathrm{M}+\mathrm{H})$; HRMS (ESI) calcd for $\mathrm{C}_{16} \mathrm{H}_{12} \mathrm{BrN}_{2} \mathrm{O}_{2}(\mathrm{M}+\mathrm{H}), 343.0082$; found 343.0085; ${ }^{1} \mathrm{H}$ NMR (400 MHz, Acetone- $\left.d_{6}\right) \delta 11.71(\mathrm{~s}, 1 \mathrm{H}), 10.23(\mathrm{~s}, 1 \mathrm{H}), 8.11(\mathrm{~d}, J=8.7 \mathrm{~Hz}, 2 \mathrm{H}), 7.92(\mathrm{~d}$, $J=8.7 \mathrm{~Hz}, 1 \mathrm{H}), 7.31(\mathrm{~d}, J=2.4 \mathrm{~Hz}, 1 \mathrm{H}), 7.30-7.21(\mathrm{~m}, 4 \mathrm{H}), 7.16(\mathrm{dd}, J=8.7,2.4 \mathrm{~Hz}, 1 \mathrm{H})$, 7.09 (s, 1H). 13C NMR (100 MHz, Acetone) $\delta$ 191.3, 164.8, 156.2, 147.1, 133.4, 131.3, 130.55, $130.45,129.3,128.8$ (2C), 123.6, 122.5 (2C), 119.0, 118.8.

\section{2-bromo-4-(2-(pyridin-3-yl)-1H-imidazol-1-yl)benzaldehyde (26)}

Fragment 26 was synthesized according to general synthesis procedure 2 using 3-bromo-4fluorobenzaldehyde (300 mg, $1.5 \mathrm{mmol}), \mathrm{K}_{2} \mathrm{CO}_{3}(210 \mathrm{mg}, 1.5 \mathrm{mmol})$ and 3-(1H-Imidazol-2yl)-pyridine $(150 \mathrm{mg}, 1.0 \mathrm{mmol})$ to afford an amorphous cream solid (120 mg, 37\%); LRMS (ESI+) $m / z 328\left(\mathrm{M}+\mathrm{H}\right.$,); HRMS (ESI) calcd for $\mathrm{C}_{15} \mathrm{H}_{10} \mathrm{BrN}_{3} \mathrm{O}(\mathrm{M}+\mathrm{H}), 328.0085$; found 328.0077; ${ }^{1} \mathrm{H}$ NMR (400 MHz, Acetone- $\left.d_{6}\right) \delta 10.33(\mathrm{~s}, 1 \mathrm{H}), 8.63(\mathrm{~d}, J=2.2 \mathrm{~Hz}, 1 \mathrm{H}), 8.54(\mathrm{dd}$, $J=4.9,1.6 \mathrm{~Hz}, 1 \mathrm{H}), 7.95(\mathrm{~d}, J=8.3 \mathrm{~Hz}, 1 \mathrm{H}), 7.85(\mathrm{~d}, J=2.0 \mathrm{~Hz}, 1 \mathrm{H}), 7.75(\mathrm{~d}, J=8.0 \mathrm{~Hz}$, $1 \mathrm{H}), 7.60(\mathrm{~d}, J=1.3 \mathrm{~Hz}, 1 \mathrm{H}), 7.51(\mathrm{dd}, J=8.3,2.0 \mathrm{~Hz}, 1 \mathrm{H}), 7.34(\mathrm{dd}, J=8.0,4.8 \mathrm{~Hz}, 1 \mathrm{H})$, 
$7.28(\mathrm{~d}, J=1.3 \mathrm{~Hz}, 1 \mathrm{H}) .13 \mathrm{C}$ NMR (100 MHz, Acetone) $\delta 190.0,149.4,149.3,143.8,143.4$, $135.6,133.0,130.9,130.8,130.0,126.5,126.5,125.8,123.4,123.1$.

\section{2-bromo-4-(2-(5-bromo-2-fluorophenyl)-1H-imidazol-1-yl)benzaldehyde (27)}

Fragment 27 was synthesized according to general synthesis procedure 1 using 3-bromo-4fluorobenzaldehyde (203 mg, $1.0 \mathrm{mmol}), \mathrm{K}_{2} \mathrm{CO}_{3}(152 \mathrm{mg}, 1.1 \mathrm{mmol})$ and 2-(2,4difluorophenyl)-1H-imidazole (176 mg, $1.1 \mathrm{mmol}$ ) to afford an amorphous beige solid ( $80 \mathrm{mg}$, $19 \%)$; LRMS (ESI+) $m / z 425\left(\mathrm{M}+\mathrm{H}, 100 \%\right.$. $\left.\mathrm{Br}^{79}, \mathrm{Br}^{81}\right)$; HRMS (ESI) calcd for $\mathrm{C}_{16} \mathrm{H}_{10} \mathrm{Br}_{2} \mathrm{FN}_{2} \mathrm{O}$ $(\mathrm{M}+\mathrm{H}), 422.9144$; found 422.9134; ${ }^{1} \mathrm{H}$ NMR $\left(399 \mathrm{MHz}\right.$, Acetone- $\left.d_{6}\right) \delta 10.30(\mathrm{~s}, 1 \mathrm{H}), 7.91(\mathrm{~d}$, $J=8.3 \mathrm{~Hz}, 1 \mathrm{H}), 7.87(\mathrm{dd}, J=6.4,2.5 \mathrm{~Hz}, 1 \mathrm{H}), 7.79(\mathrm{~s}, 1 \mathrm{H}), 7.68(\mathrm{~d}, J=11.6 \mathrm{~Hz}, 2 \mathrm{H}), 7.47(\mathrm{~d}$, $J=8.3 \mathrm{~Hz}, 1 \mathrm{H}), 7.31(\mathrm{~s}, 1 \mathrm{H}), 7.18-6.96(\mathrm{~m}, 1 \mathrm{H}) .{ }^{13} \mathrm{C}$ NMR $(100 \mathrm{MHz}$, Acetone-d6) $\delta 189.9$, 159.7, 157.2, 143.3 (d, $J=2.2 \mathrm{~Hz}), 140.4(\mathrm{~d}, J=1.3 \mathrm{~Hz}), 134.7(\mathrm{~d}, J=3.0 \mathrm{~Hz}), 134.4$ (d, $J=$ $8.5 \mathrm{~Hz}), 132.7,130.5$ (d, $J=29.6 \mathrm{~Hz}), 129.2,126.3,124.0,122.7,121.1$ (d, $J=16.2 \mathrm{~Hz}), 117.9$ $(\mathrm{d}, \mathrm{J}=23.6 \mathrm{~Hz}), 116.6(\mathrm{~d}, J=3.4 \mathrm{~Hz})$.

\section{2-bromo-4-(2-(2,4-difluorophenyl)-1H-imidazol-1-yl)benzaldehyde (28)}

Fragment 28 was synthesized according to general synthesis procedure 1 using 3-bromo-4fluorobenzaldehyde (203 mg, $1.0 \mathrm{mmol}), \mathrm{K}_{2} \mathrm{CO}_{3}(152 \mathrm{mg}, 1.1 \mathrm{mmol})$ and 2-(2,4difluorophenyl)-1H-imidazole (198 mg, $1.1 \mathrm{mmol})$ to afford an amorphous beige solid $(62 \mathrm{mg}$, 17\%); LRMS (ESI+) $\mathrm{m} / \mathrm{z} 363\left(\mathrm{M}+\mathrm{H}\right.$,); HRMS (ESI) calcd for $\mathrm{C}_{16} \mathrm{H}_{10} \mathrm{BrF}_{2} \mathrm{~N}_{2} \mathrm{O}(\mathrm{M}+\mathrm{H})$, 362.9945; found 362.9946; ${ }^{1} \mathrm{H}$ NMR (400 MHz, DMSO- $\left.d_{6}\right) \delta 10.17(\mathrm{~s}, 1 \mathrm{H}), 7.84(\mathrm{~d}, J=8.4$ $\mathrm{Hz}, 1 \mathrm{H}), 7.78(\mathrm{dd}, J=16.9,1.8 \mathrm{~Hz}, 2 \mathrm{H}), 7.68(\mathrm{td}, J=8.2,6.3 \mathrm{~Hz}, 1 \mathrm{H}), 7.35$ (ddd, $J=8.3,2.1$, $0.7 \mathrm{~Hz}, 1 \mathrm{H}), 7.30(\mathrm{~d}, J=1.4 \mathrm{~Hz}, 1 \mathrm{H}), 7.28-7.20(\mathrm{~m}, 2 \mathrm{H}) ;{ }^{13} \mathrm{C} \mathrm{NMR}\left(101 \mathrm{MHz}, \mathrm{DMSO}-d_{6}\right) \delta$ 190.7, $163.0(\mathrm{dd}, J=249.4,12.3 \mathrm{~Hz}), 159.1(\mathrm{dd}, J=250.3,12.8 \mathrm{~Hz}), 142.6(\mathrm{~d}, J=1.4 \mathrm{~Hz})$, $140.3(\mathrm{~d}, J=1.0 \mathrm{~Hz}), 133.6(\mathrm{dd}, J=10.0,4.0 \mathrm{~Hz}), 132.0,131.0,129.8,129.0,125.9,123.9$, $122.7,115.1$ (dd, $J=14.9,3.8 \mathrm{~Hz}), 112.4(\mathrm{dd}, J=21.7,3.5 \mathrm{~Hz}), 104.5(\mathrm{t}, J=26.0 \mathrm{~Hz})$. 


\section{NMR Spectra}

Fragment 1

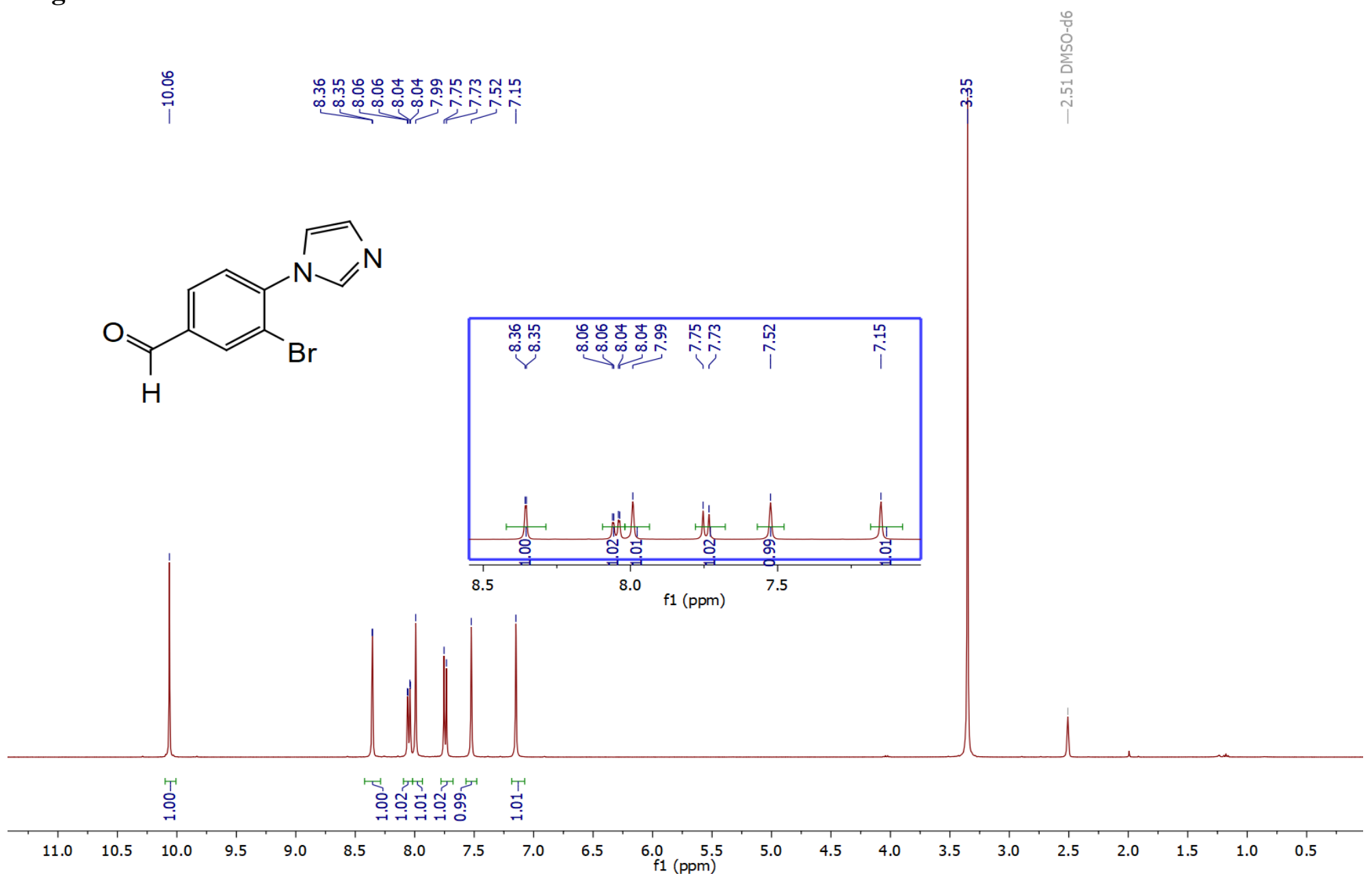



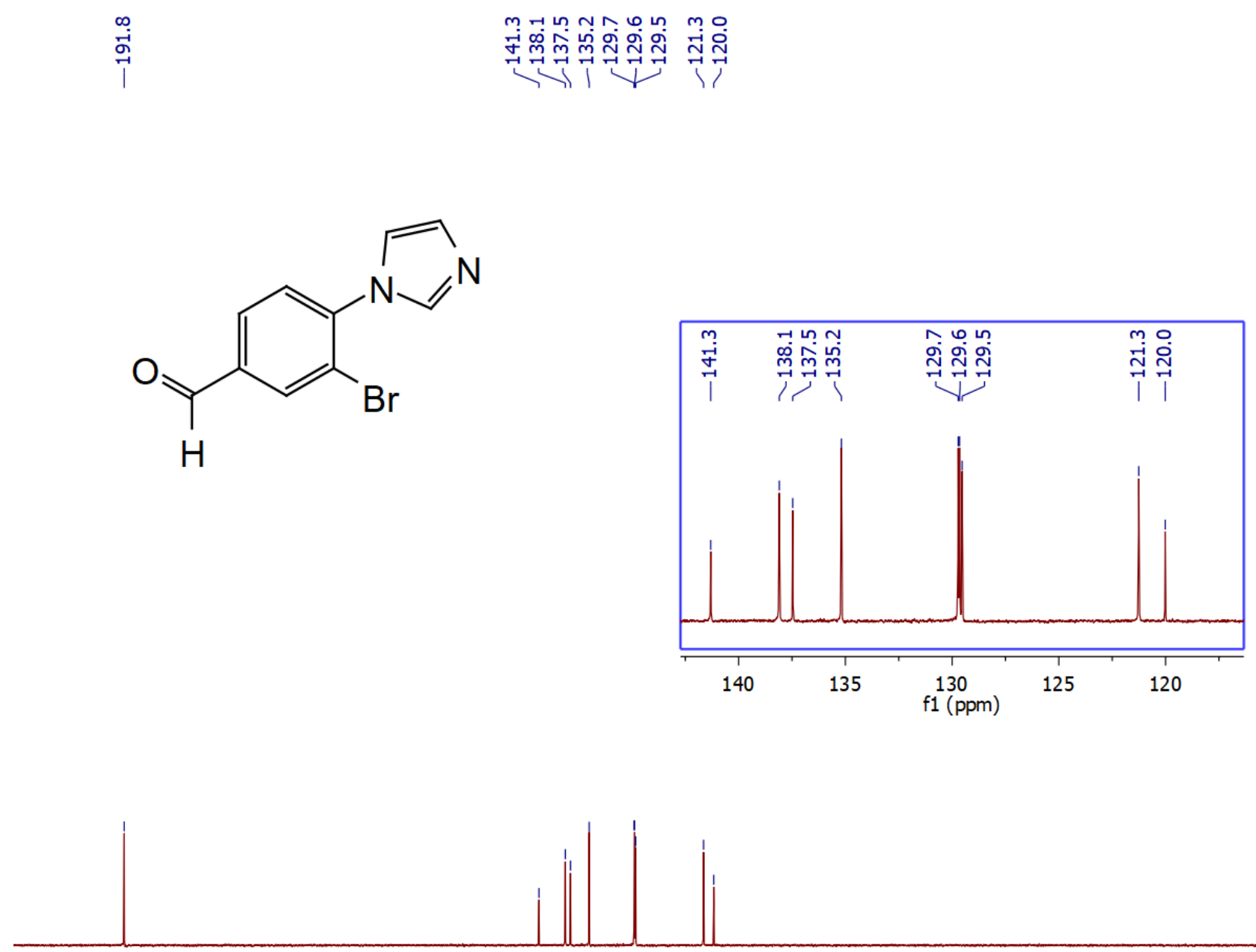
Fragment 2

PC2043A_FC.1.fid
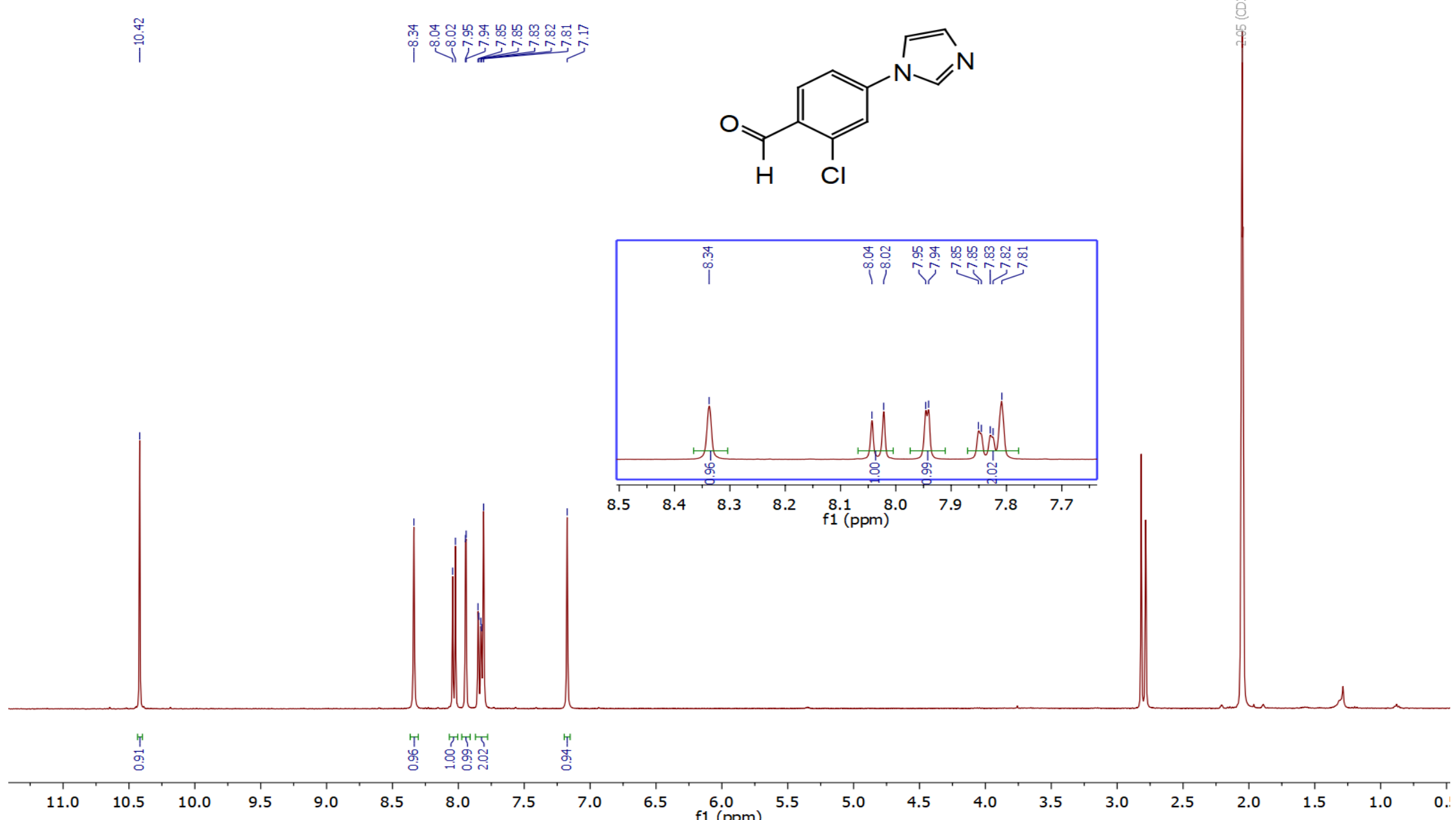
PC2043A_FC.2.fid
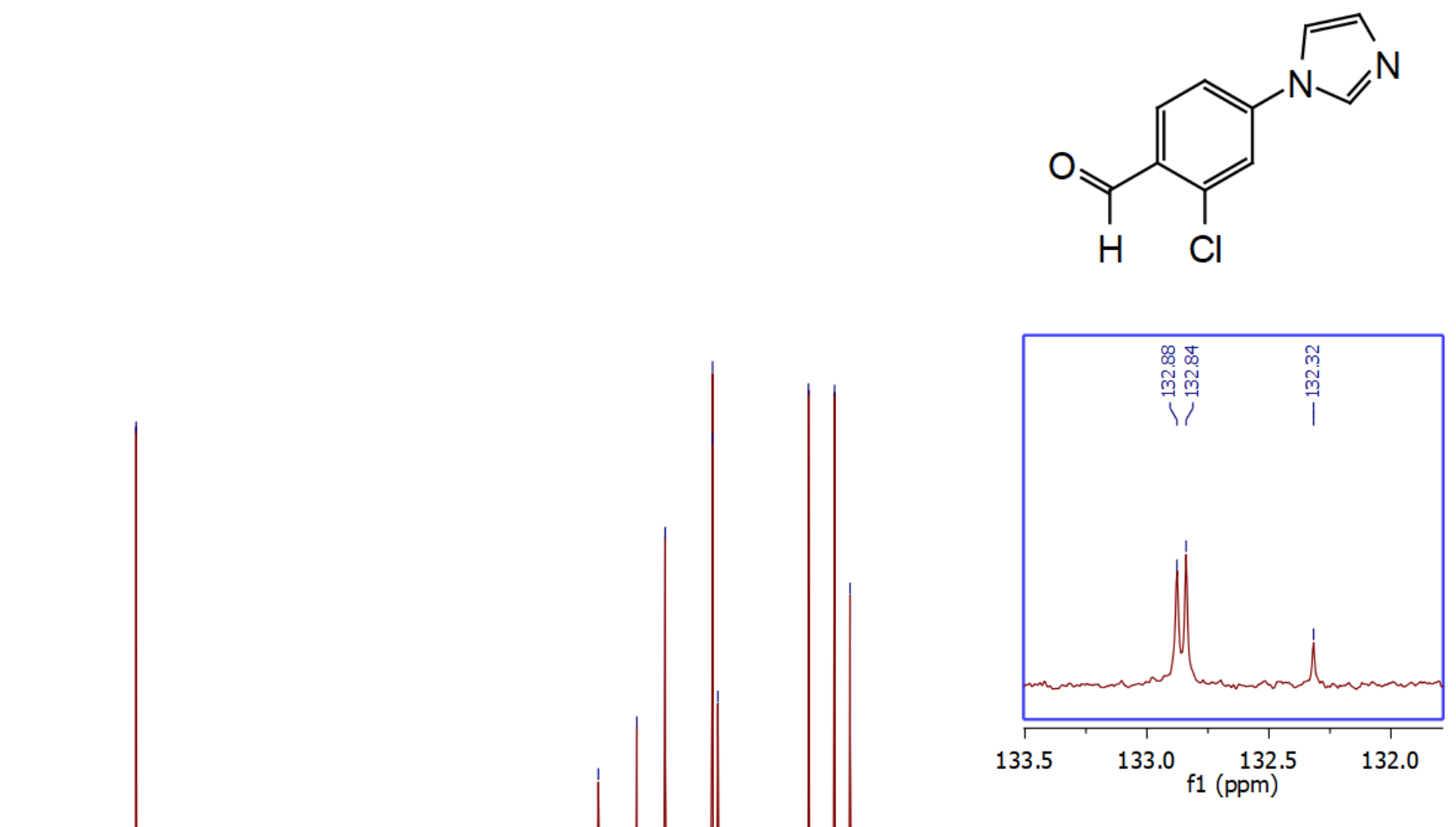

1.14

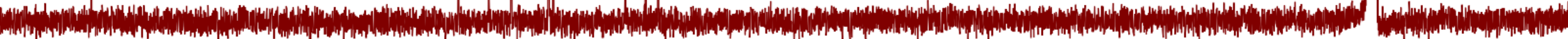

$00 \quad 190$

$180 \quad 170$

160

150

130

120

$110 \quad 100$
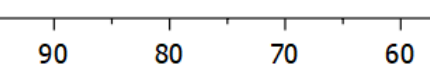

50

40

30 $20 \quad 10$ 
Fragment 3

LvD1008 Jan31 1. fid

|

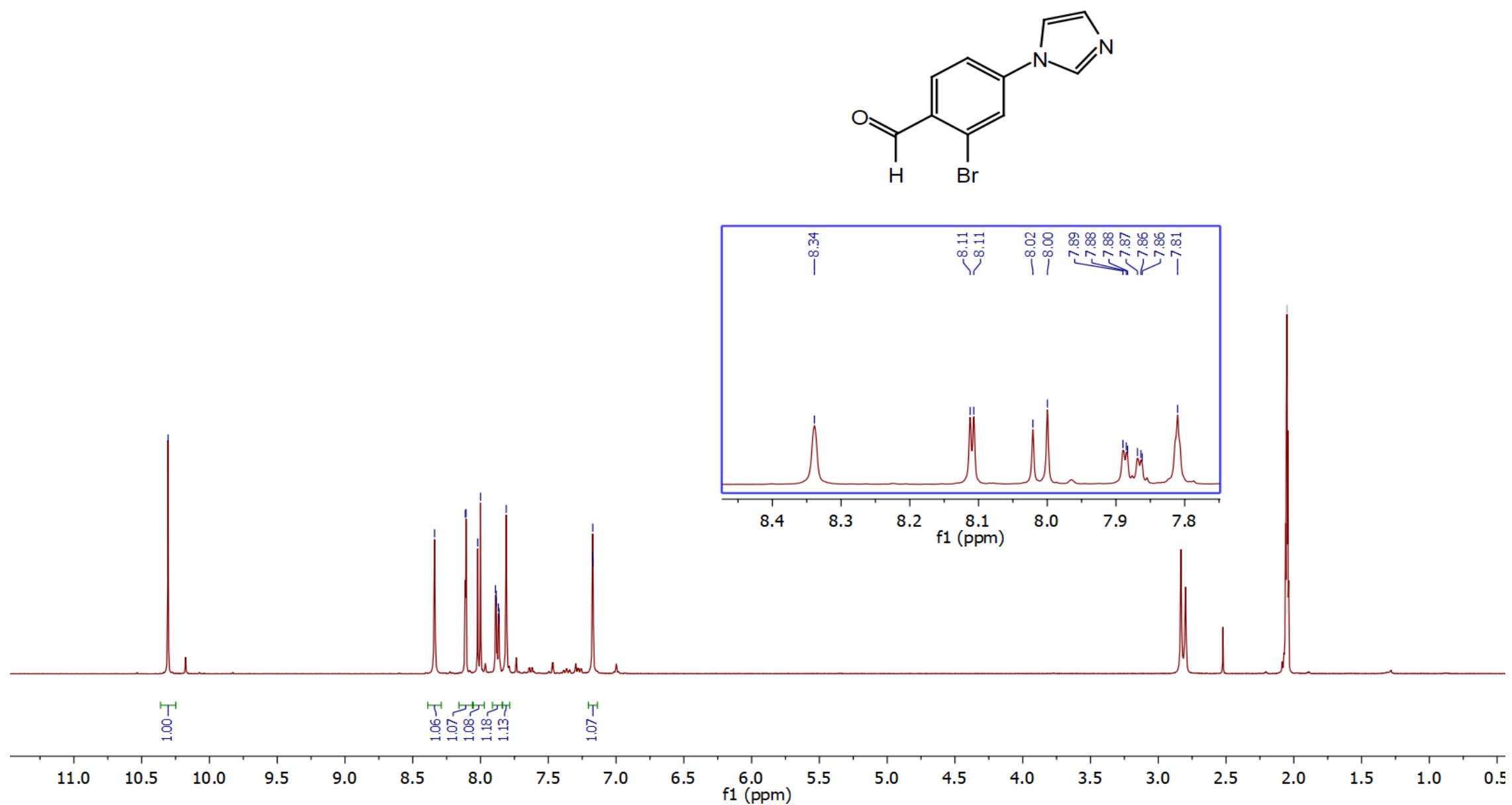


LvD1008_Jan31.2.fid

옹

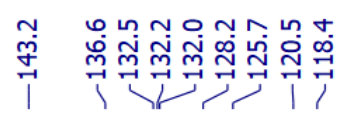
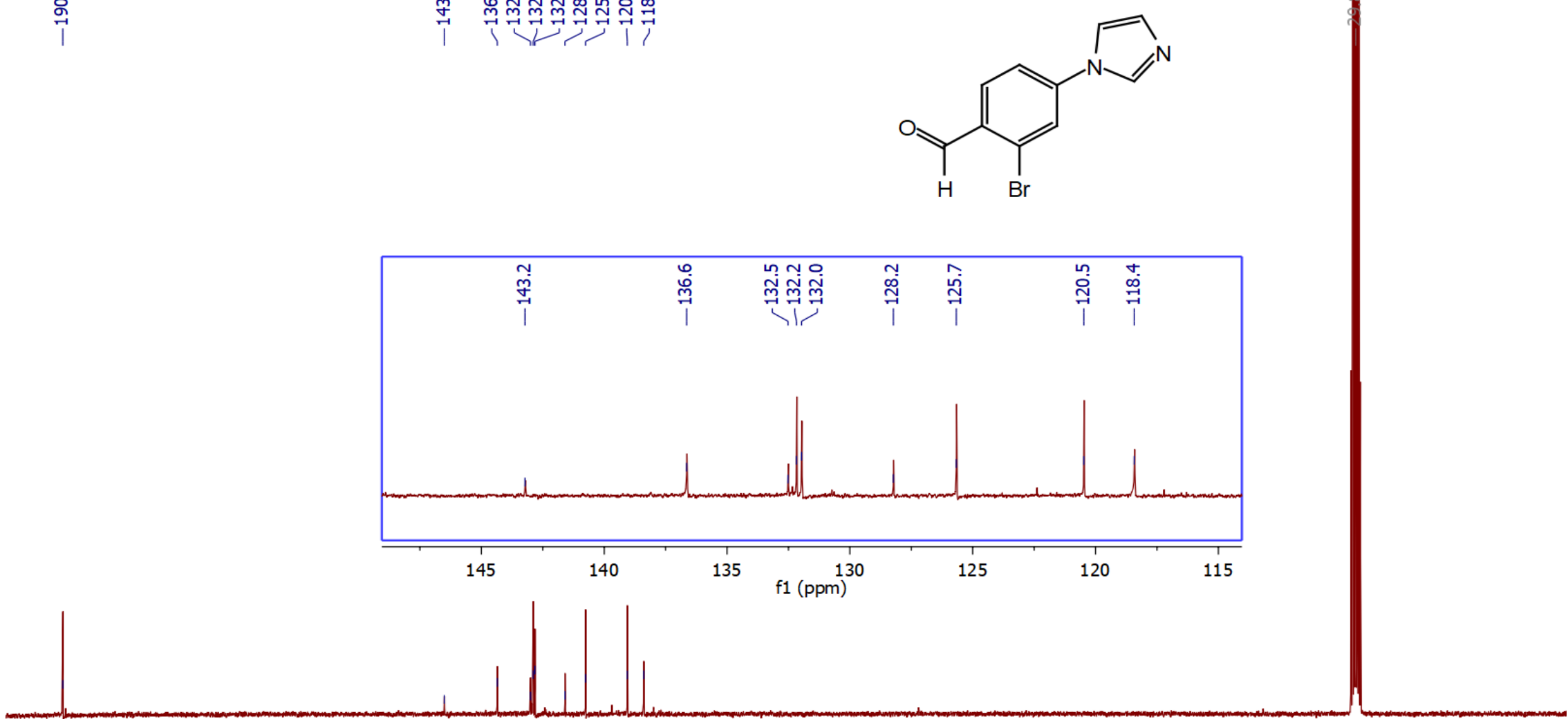
Fragment 4

LvD1002F1_Jan31.1.fid

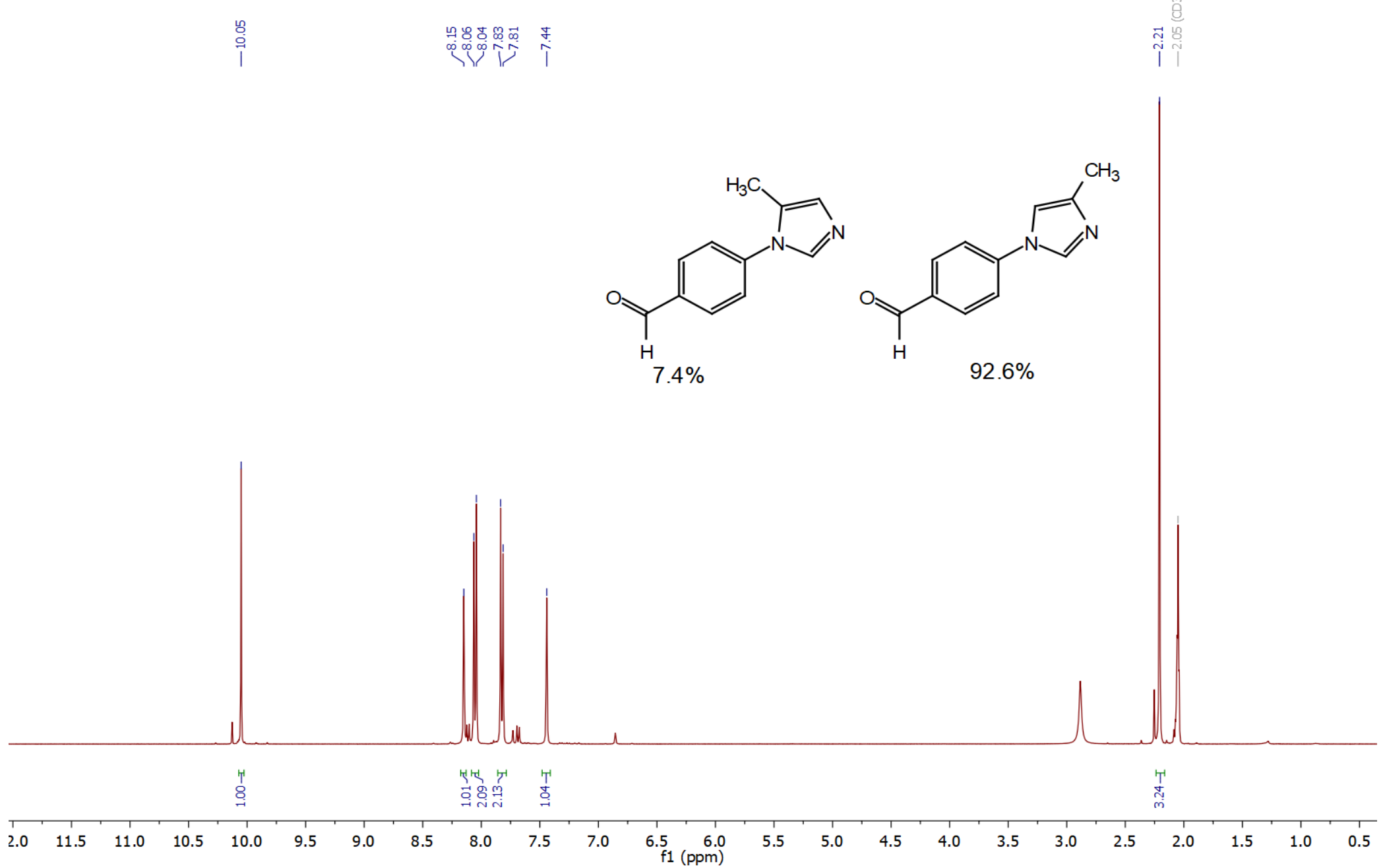


LvD1002F1_Jan31.2.fid
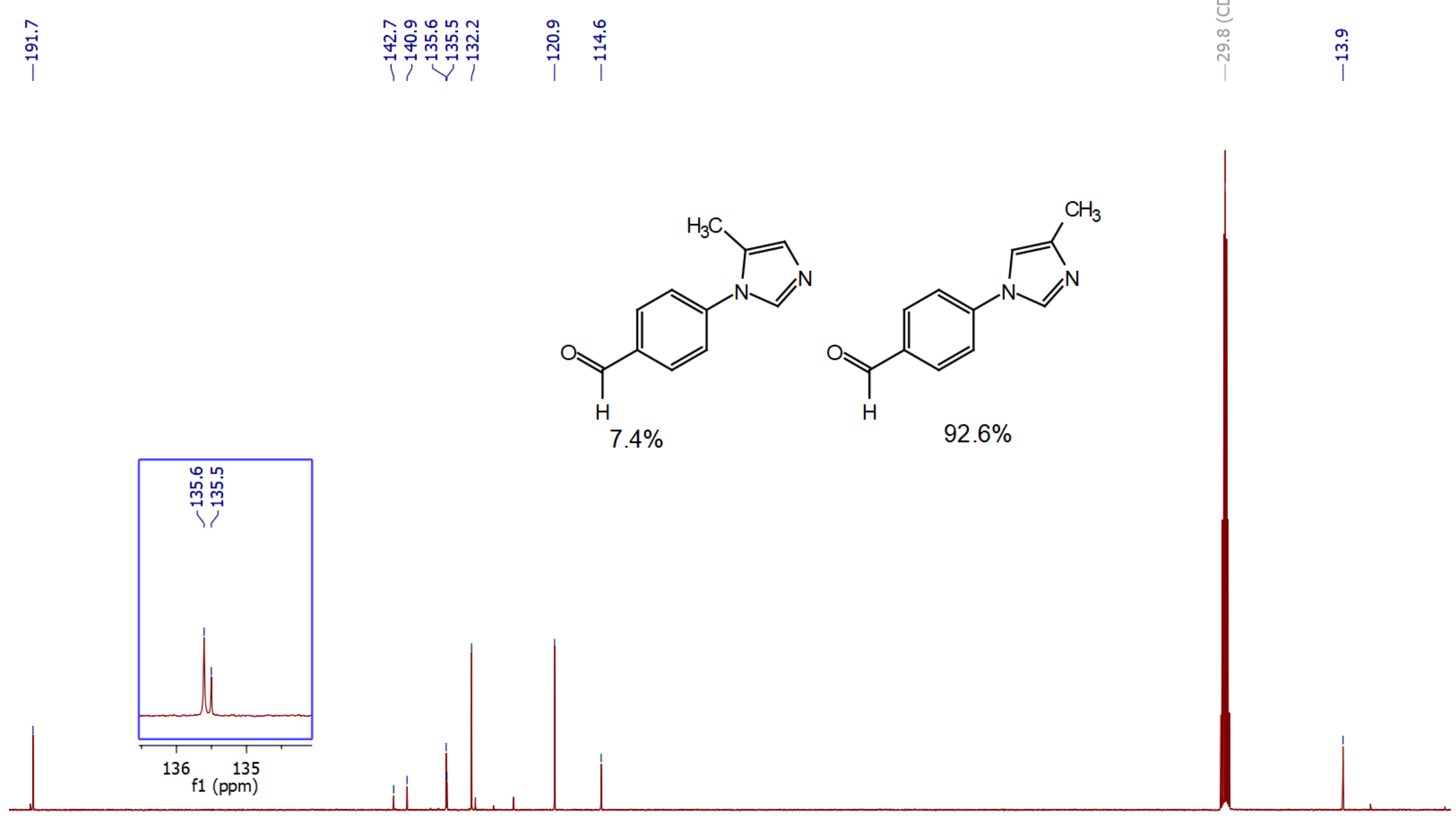

$190 \quad 180$

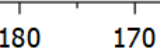

160

$100 \quad 90$ 
Fragment 6

LvD1005 Jan31.1.fid
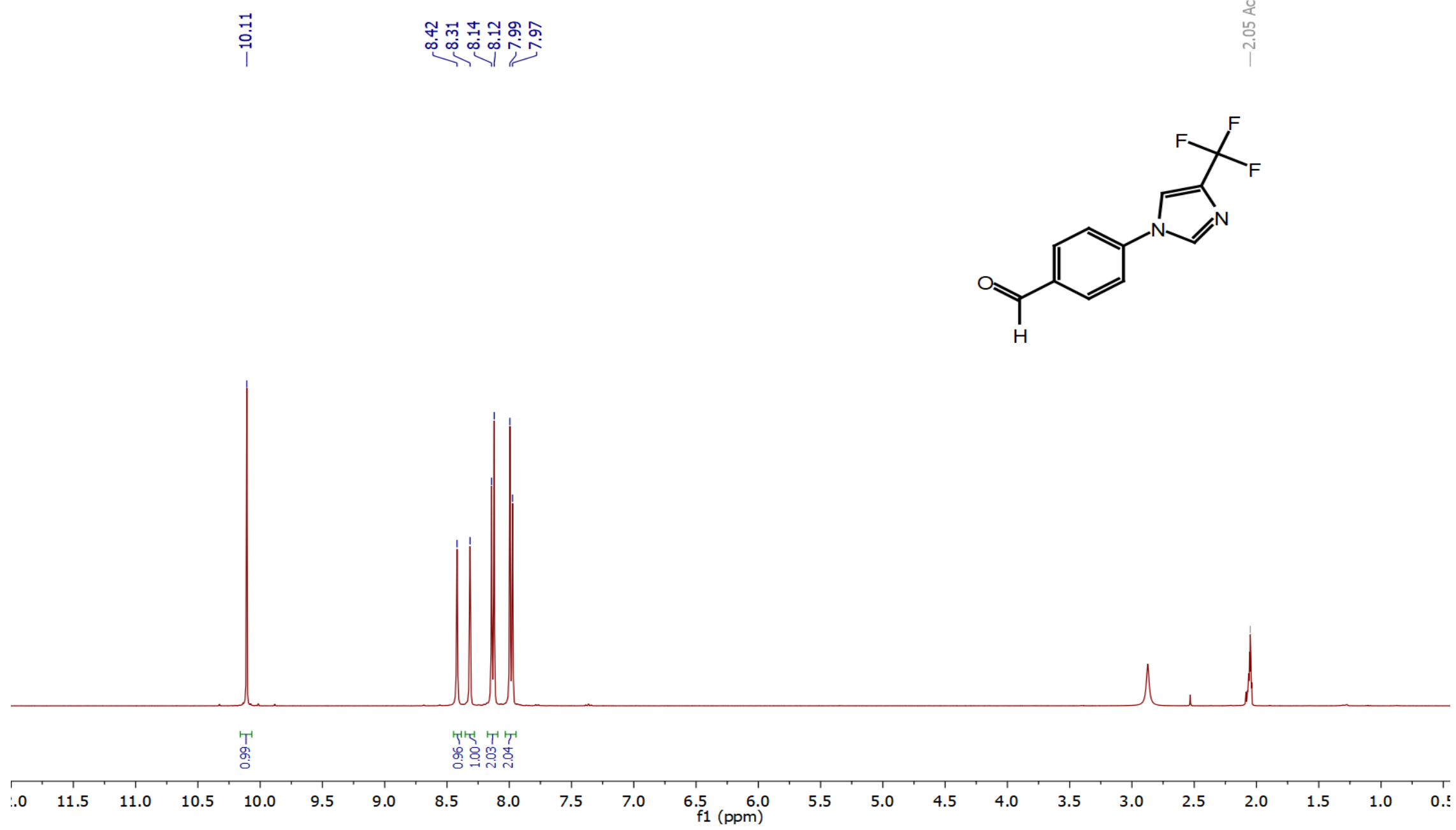
LvD1005_Jan31.2.fid
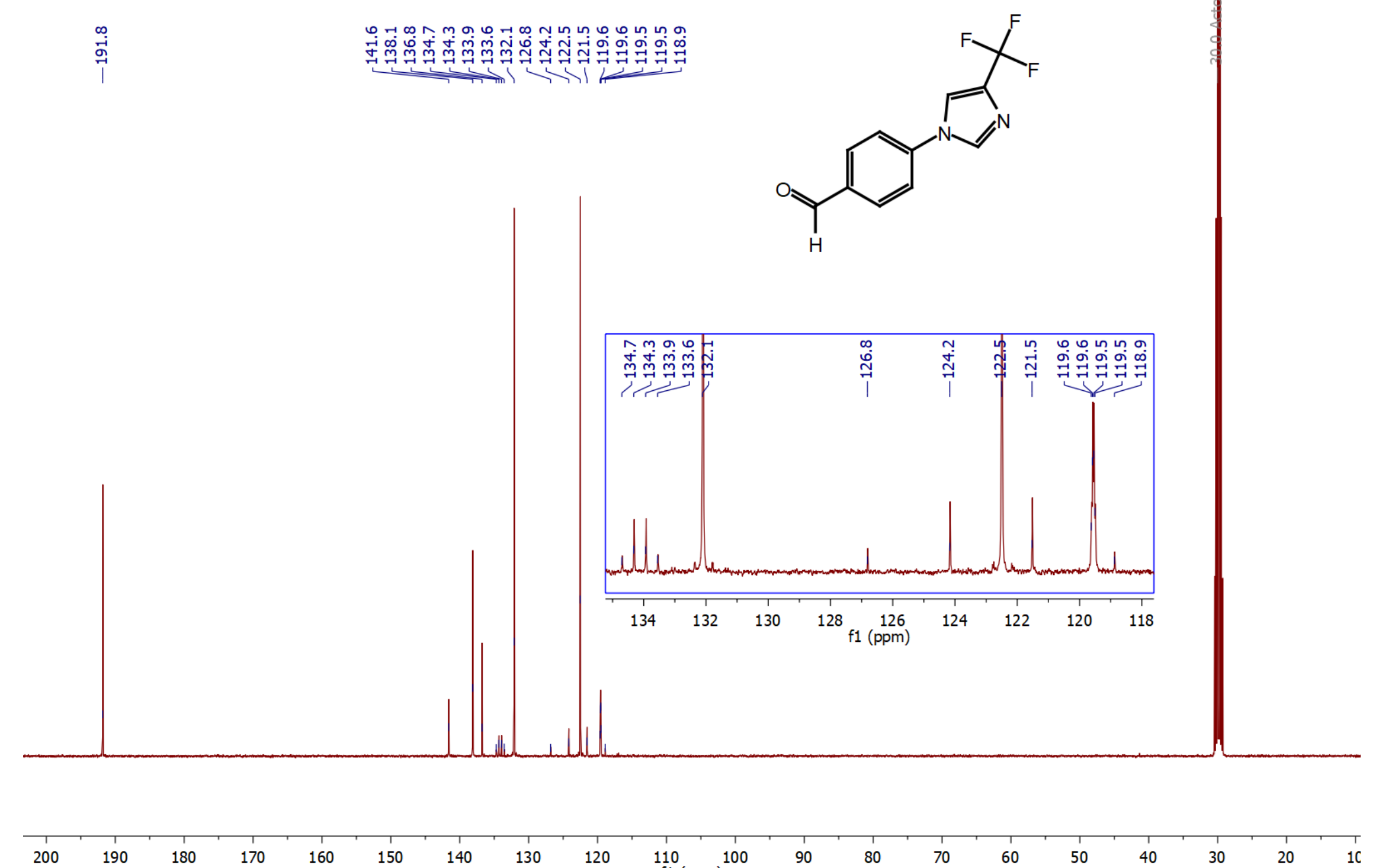
Fragment 7

LvD1007C1.1.fid

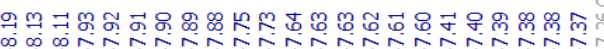
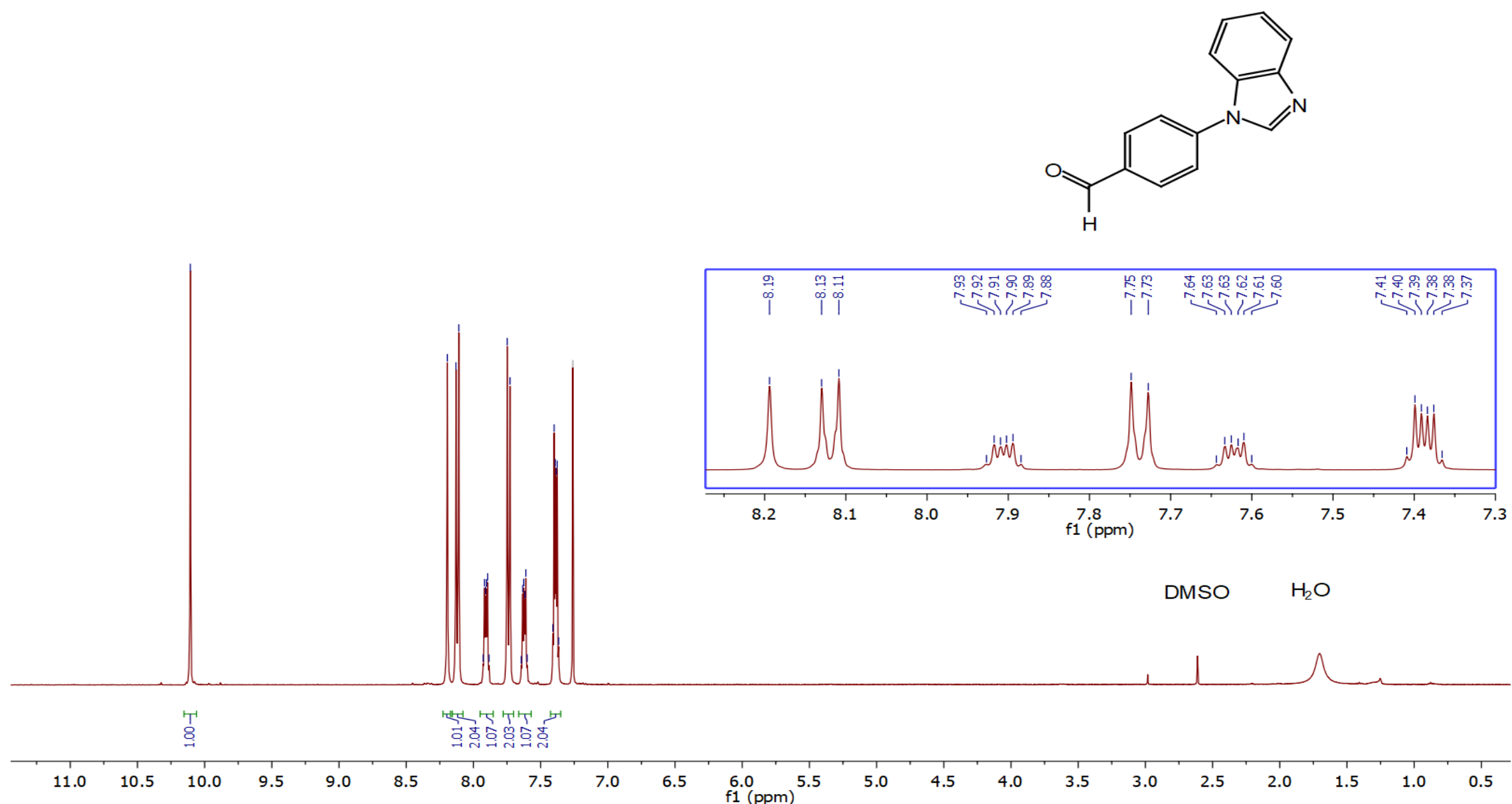
LvD1007C1.2.fid

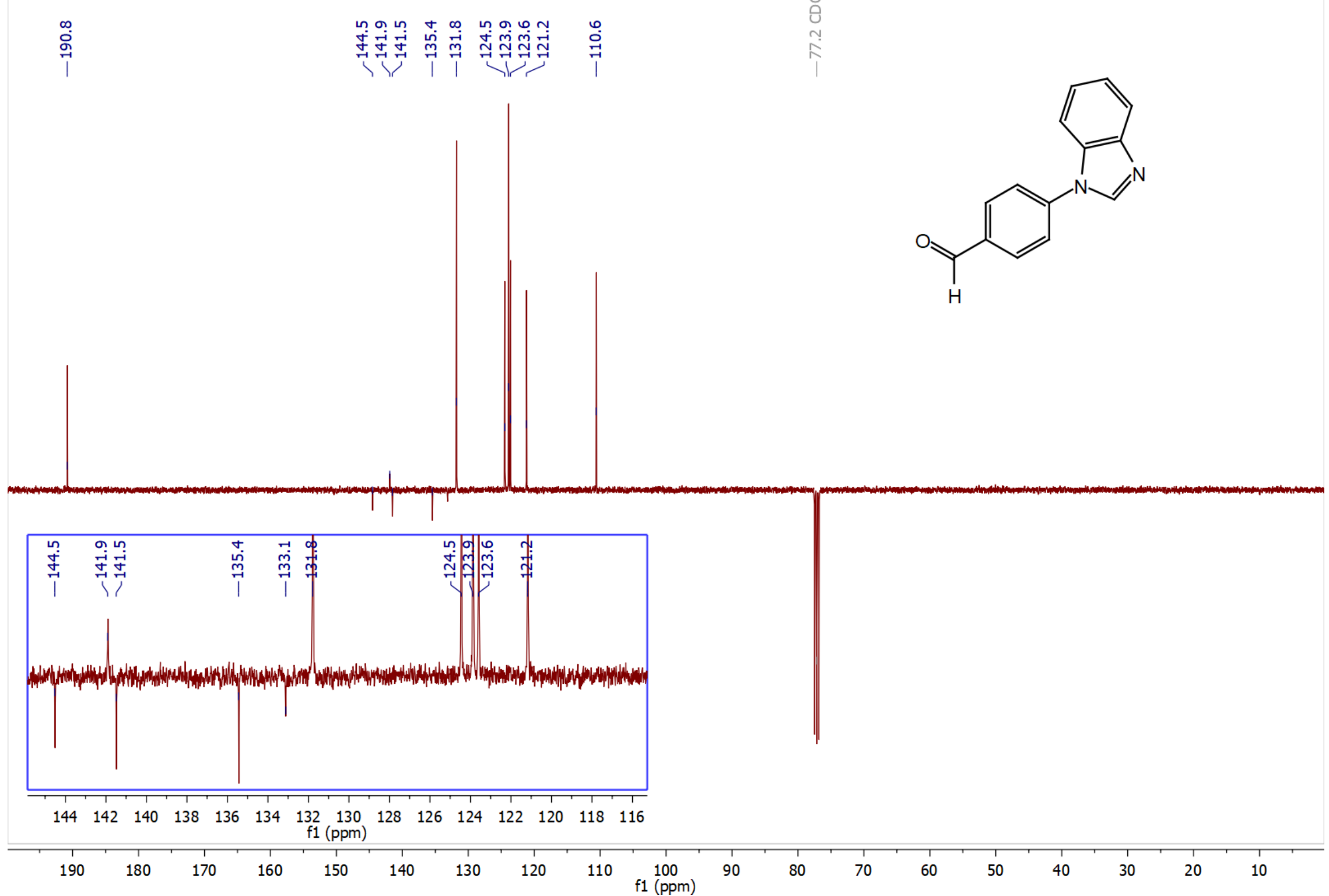


Fragment 8

PC2033_FC.1.fid

年
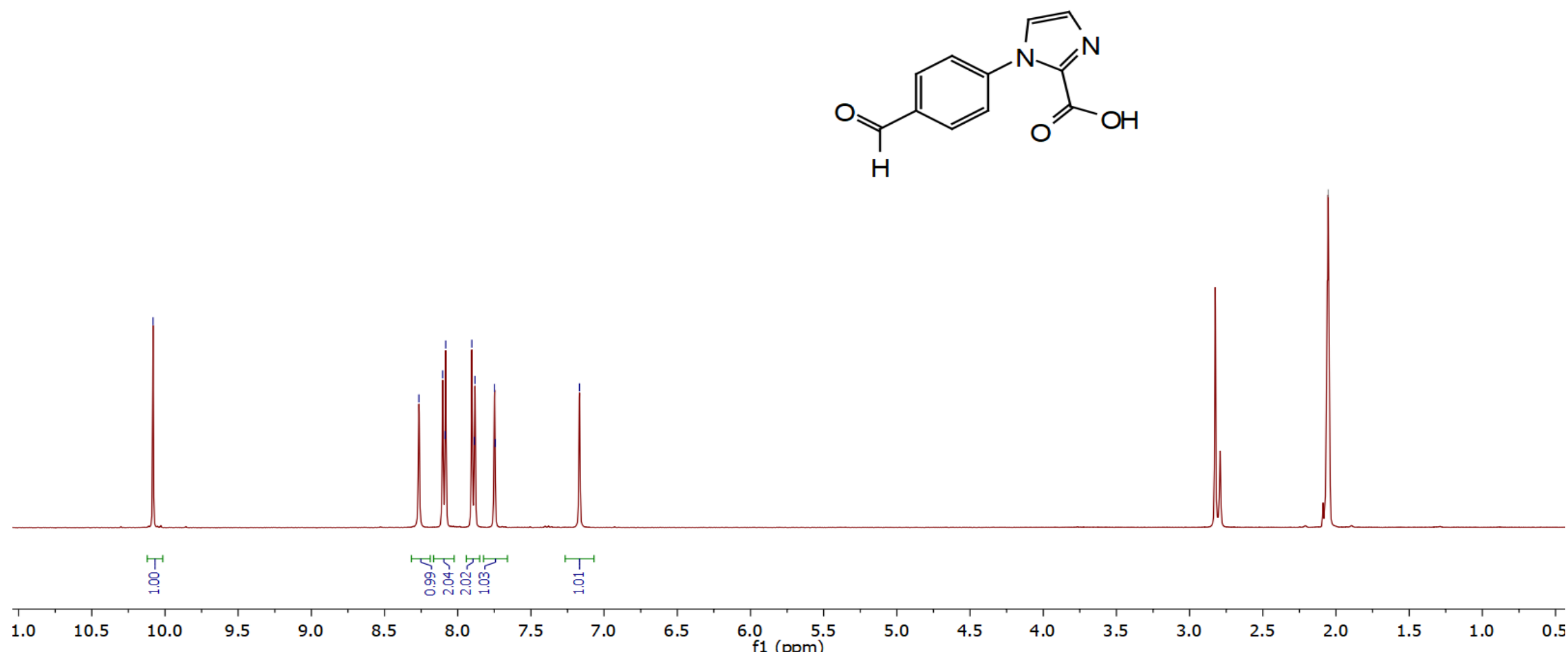

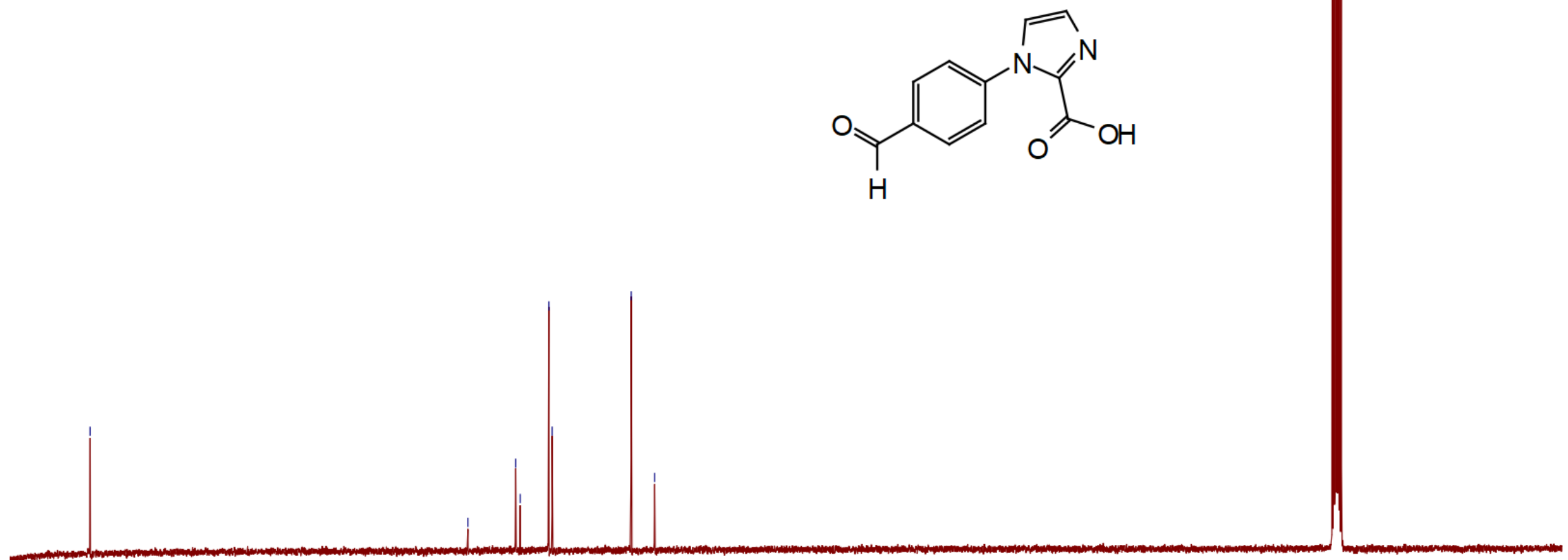
Fragment 9

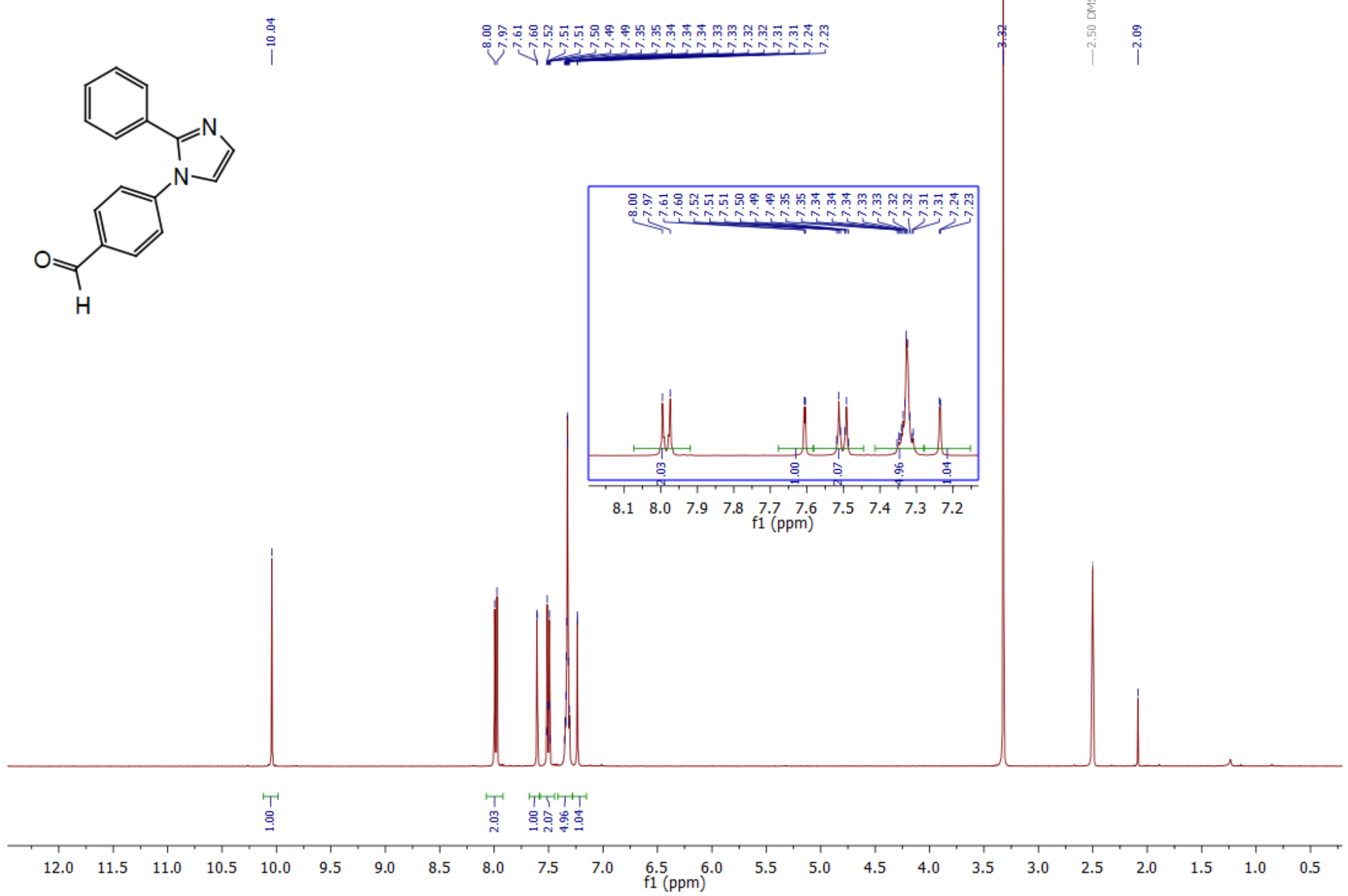



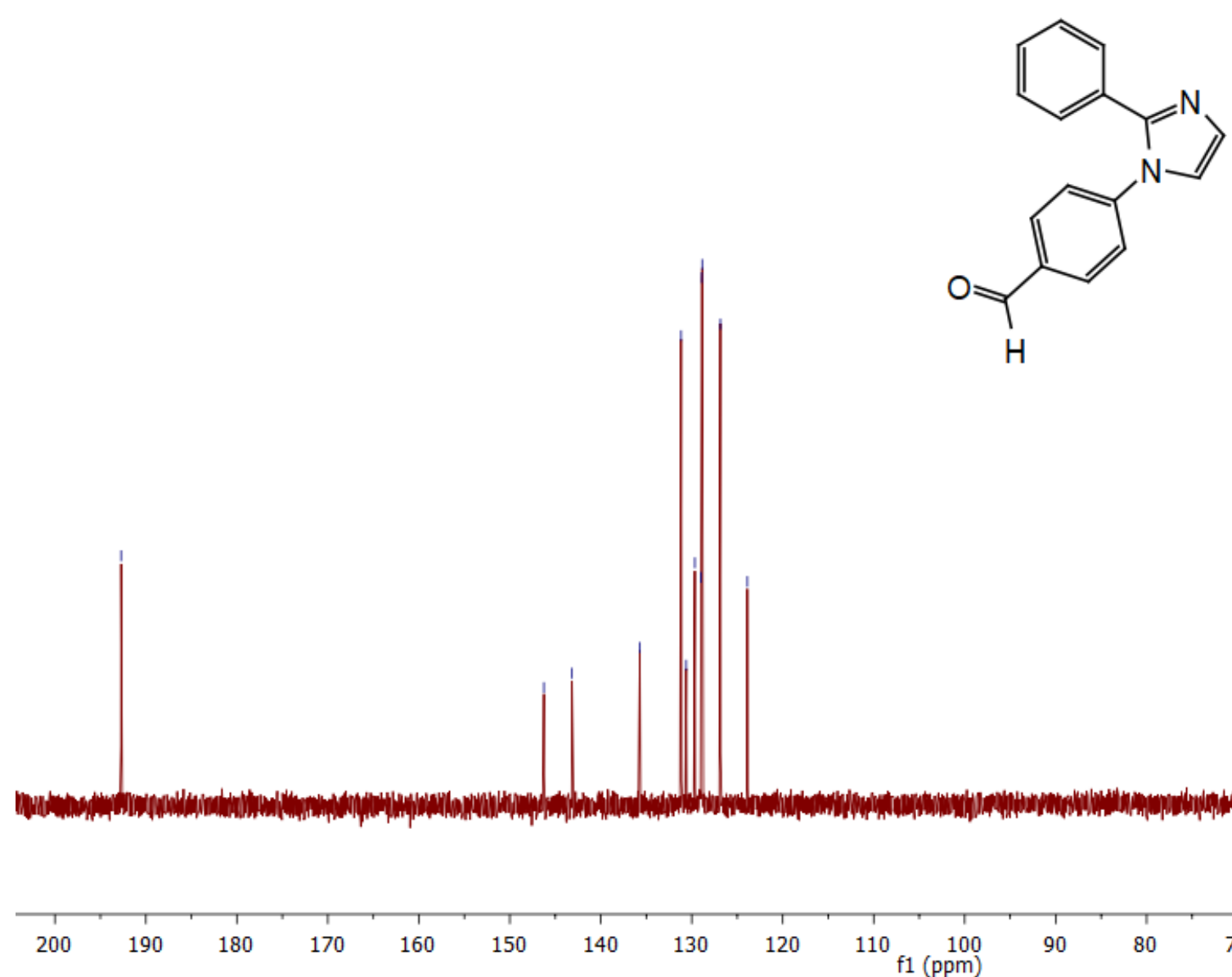
$110 \quad \begin{array}{r}100 \\ 101\end{array}$
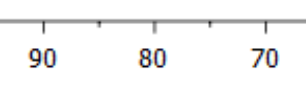

60 
Fragment 10

LVD1017.1.fid

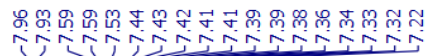

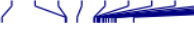

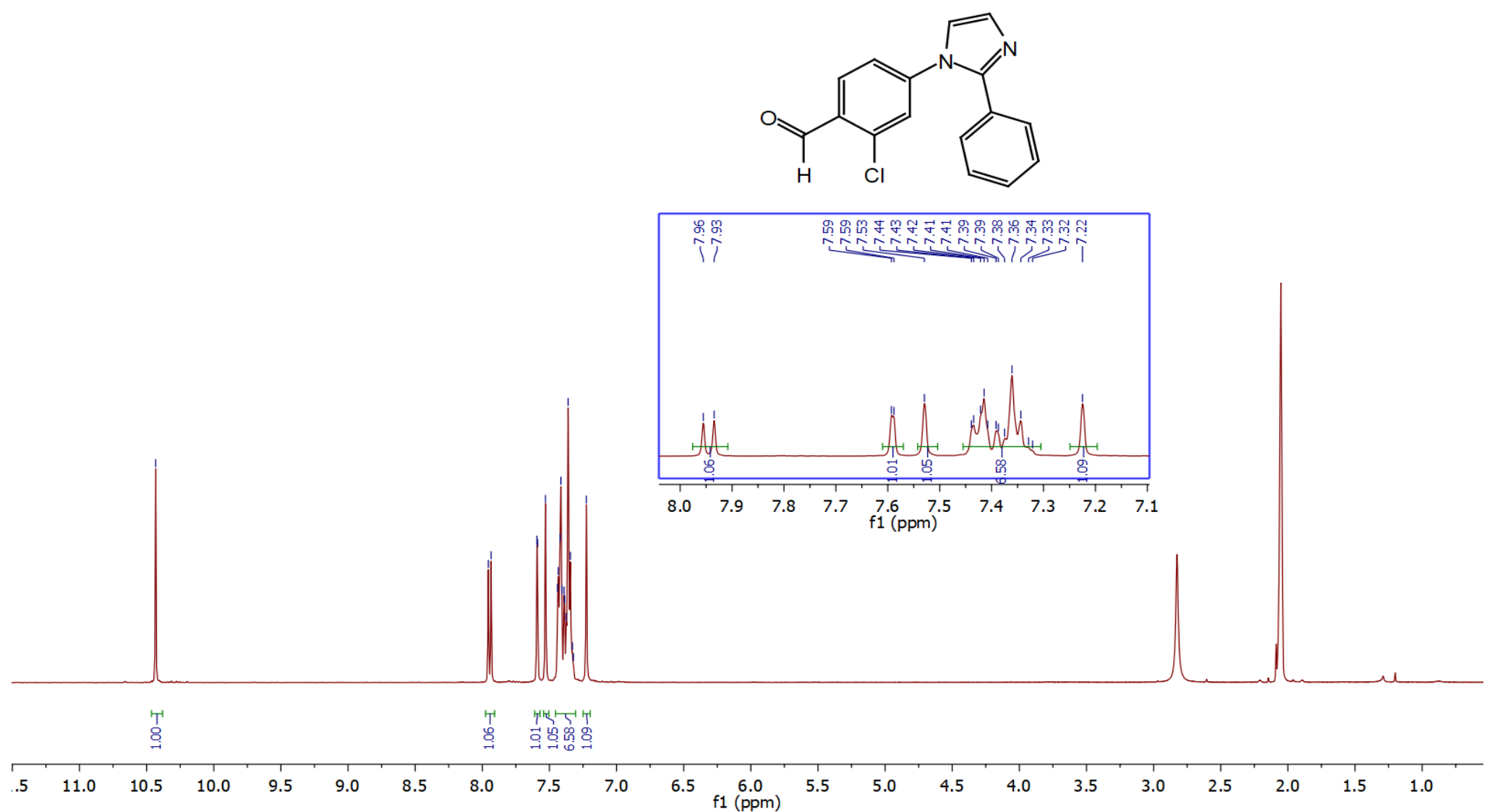



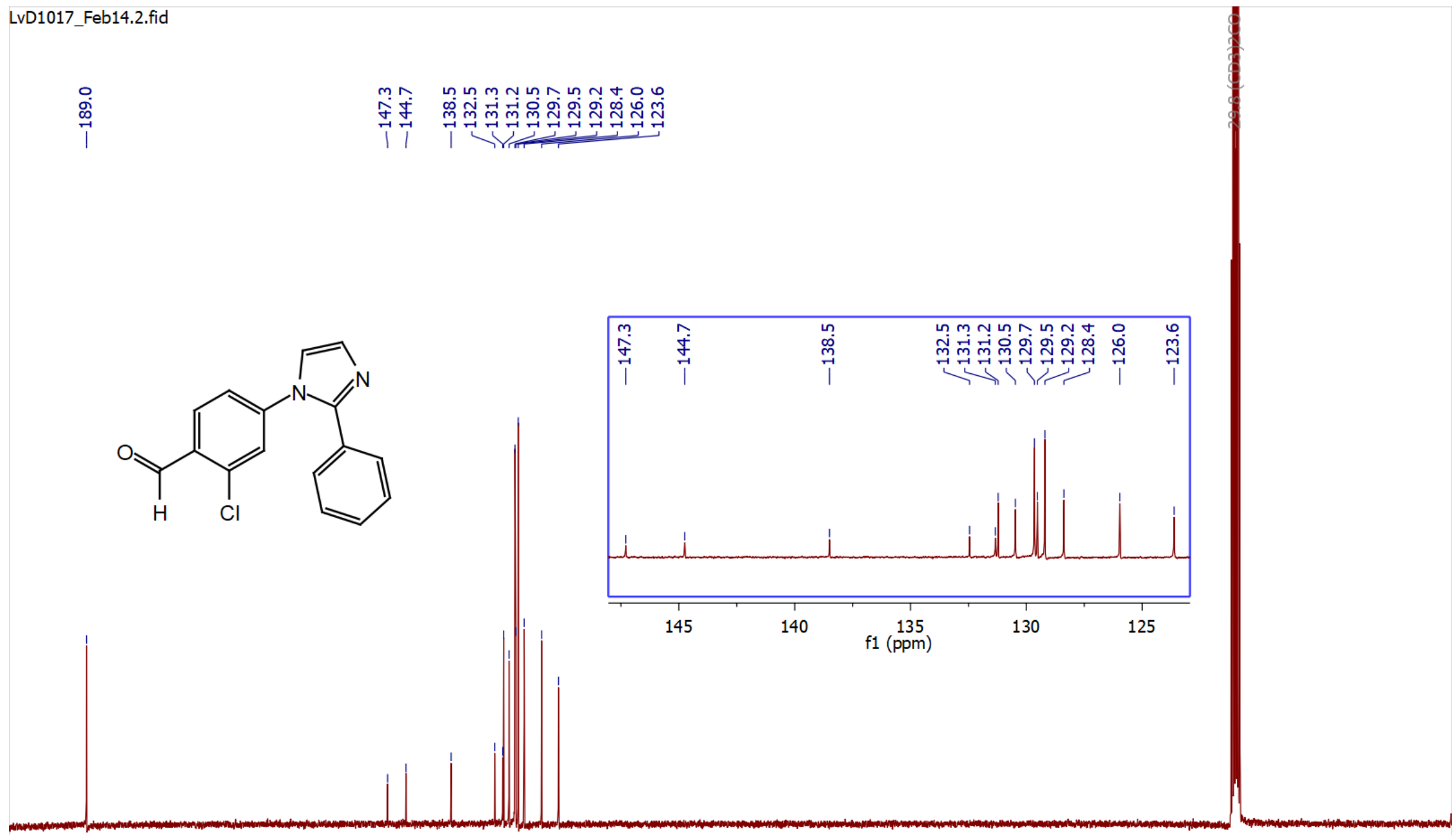

$190 \quad 180 \quad 170$

150

140
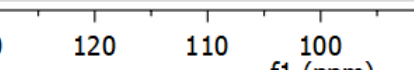

80
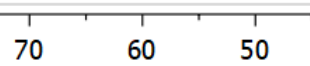

40

30

1 
Fragment 11

PC2043B FC.1.fid

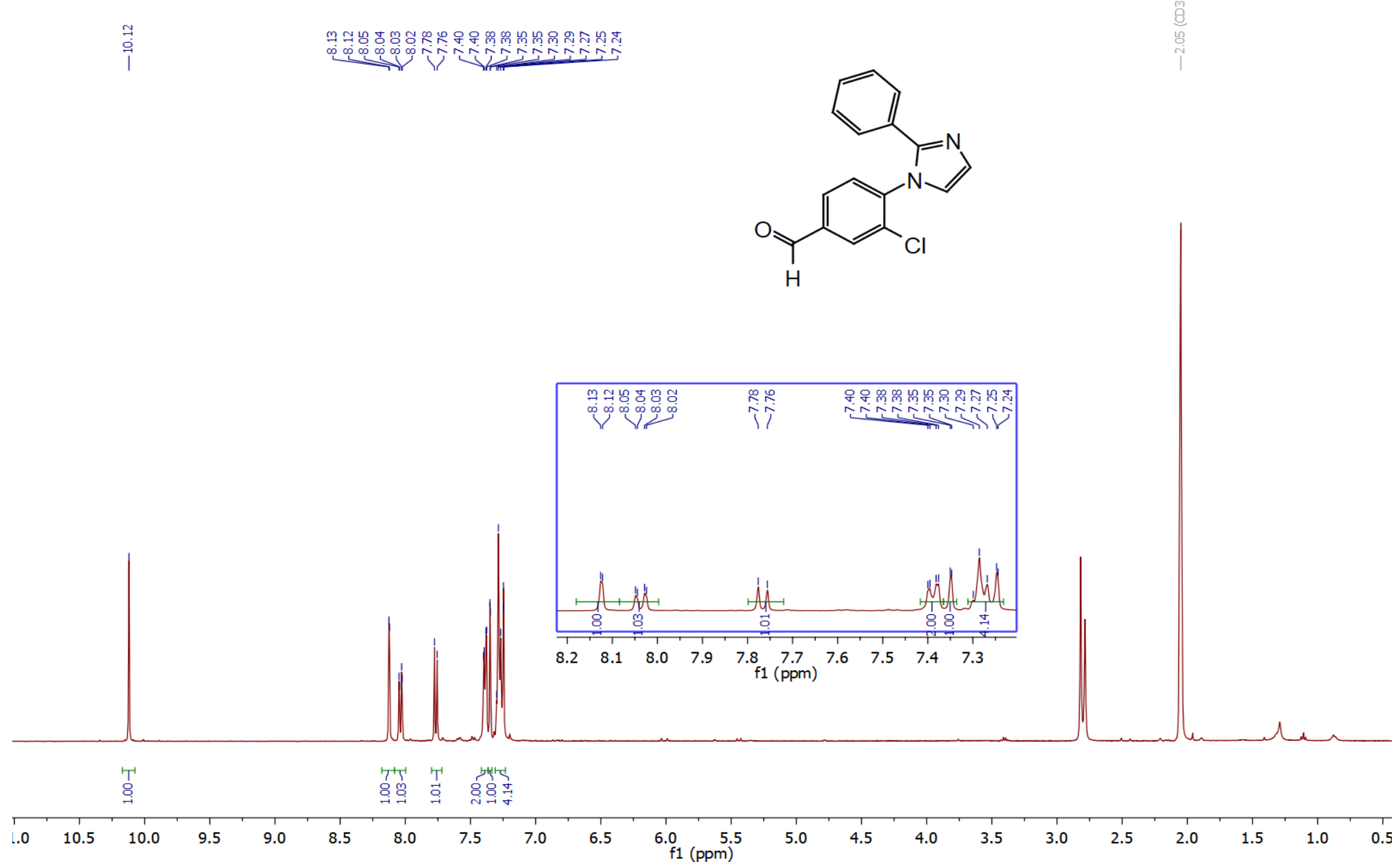


PC2043B_FC.2.fid

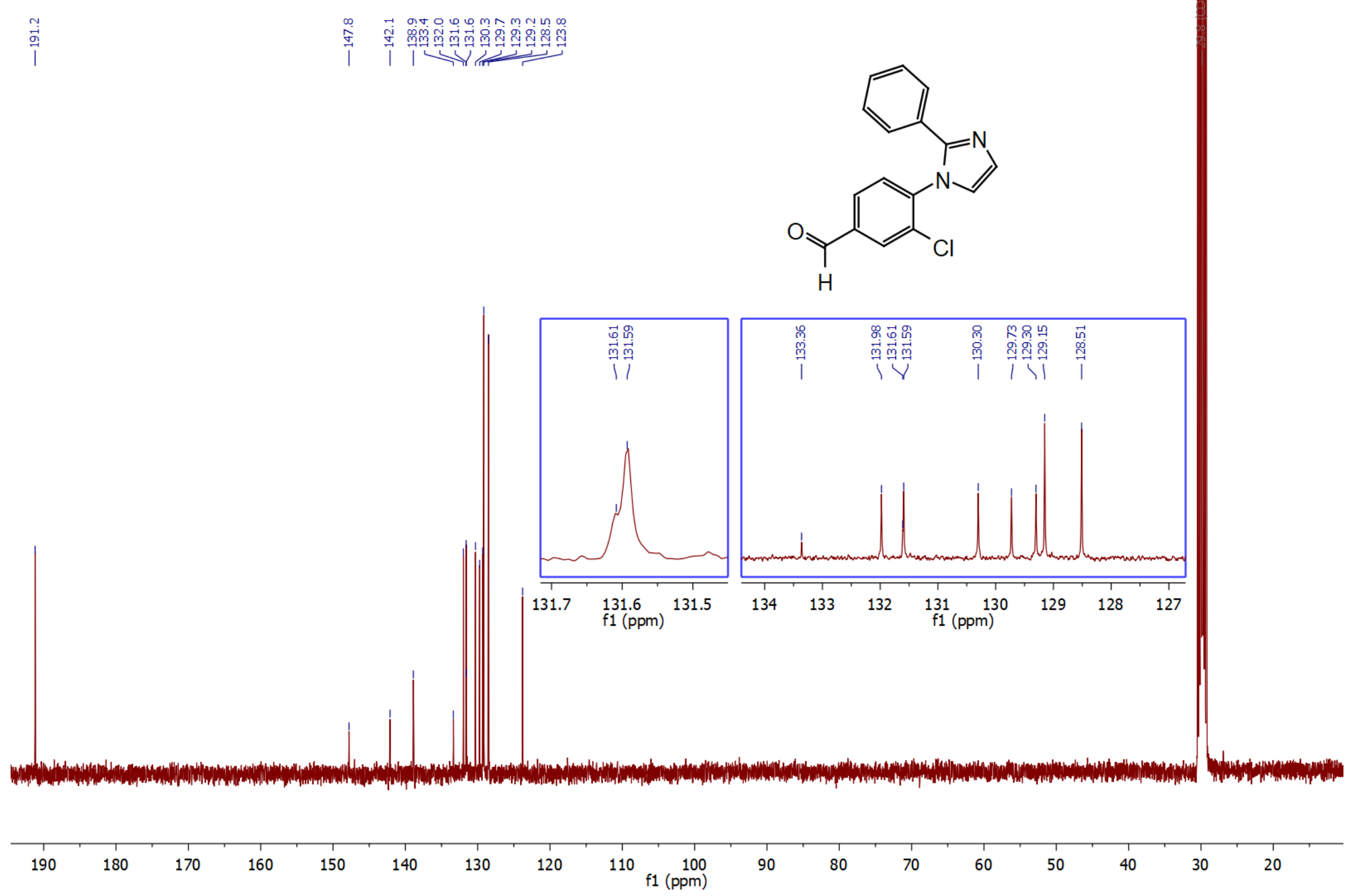


Fragment 12

LvD1010F1.1.fid

莗

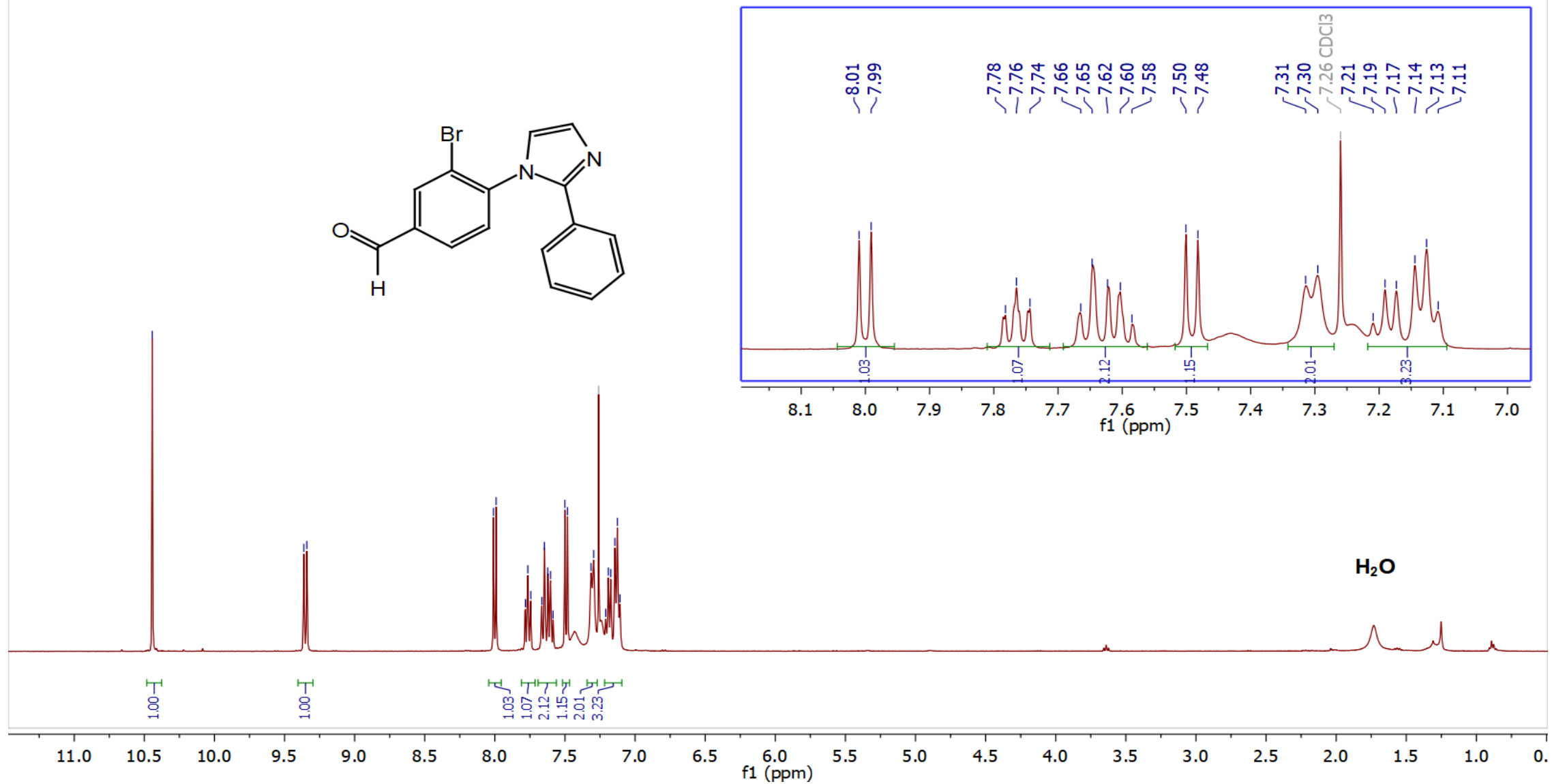


LvD1010F1.2.fid

ลิ

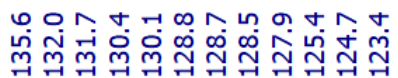

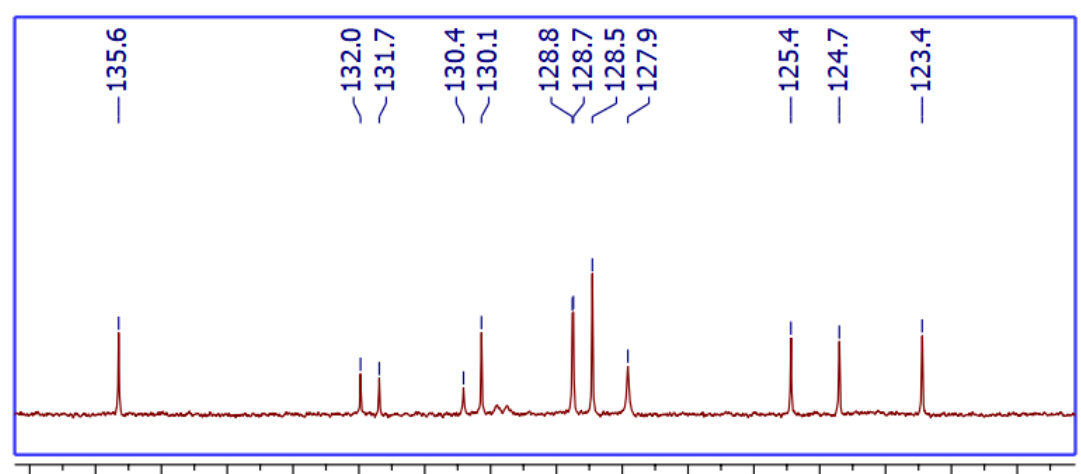

$\begin{array}{llllllllllllllll}137 & 136 & 135 & 134 & 133 & 132 & 131 & 130 & 129 & 128 & 127 & 126 & 125 & 124 & 123 & 122\end{array}$
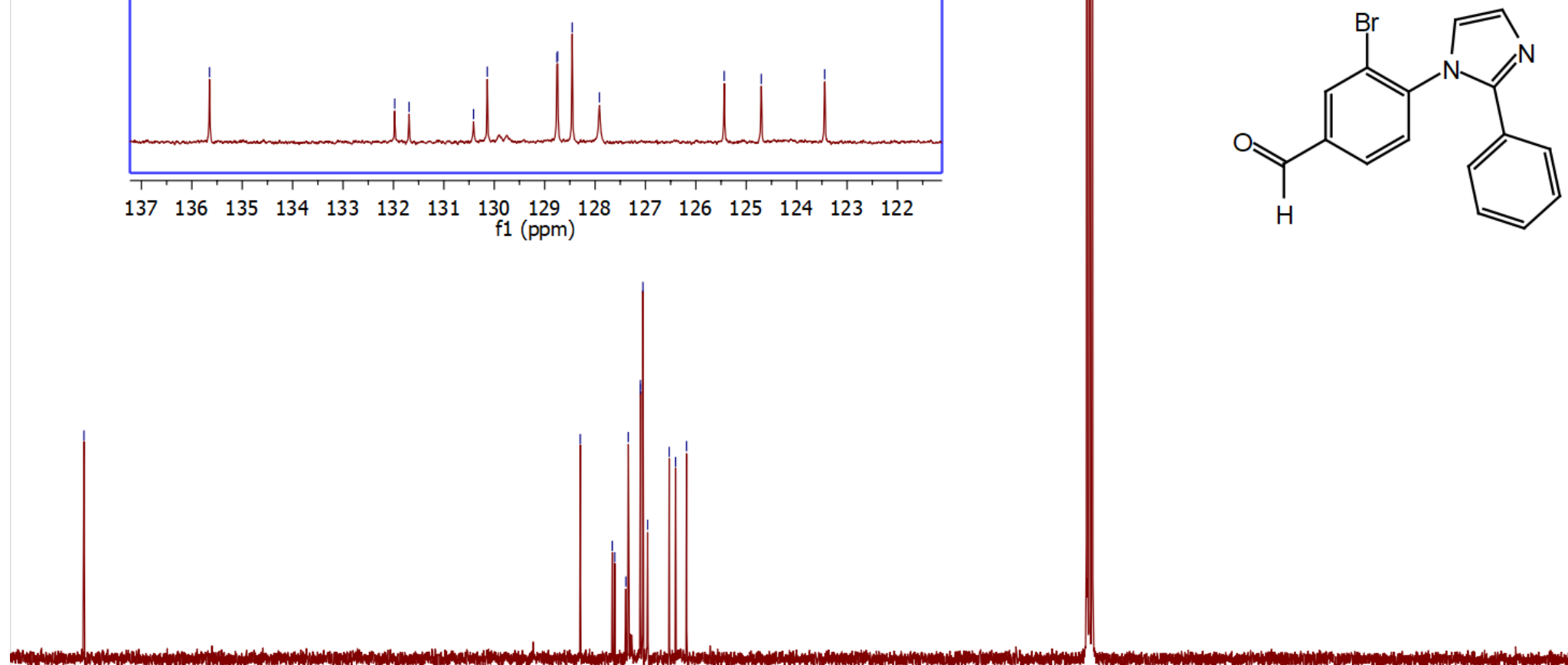
Fragment 13

LvD1009.1.fid

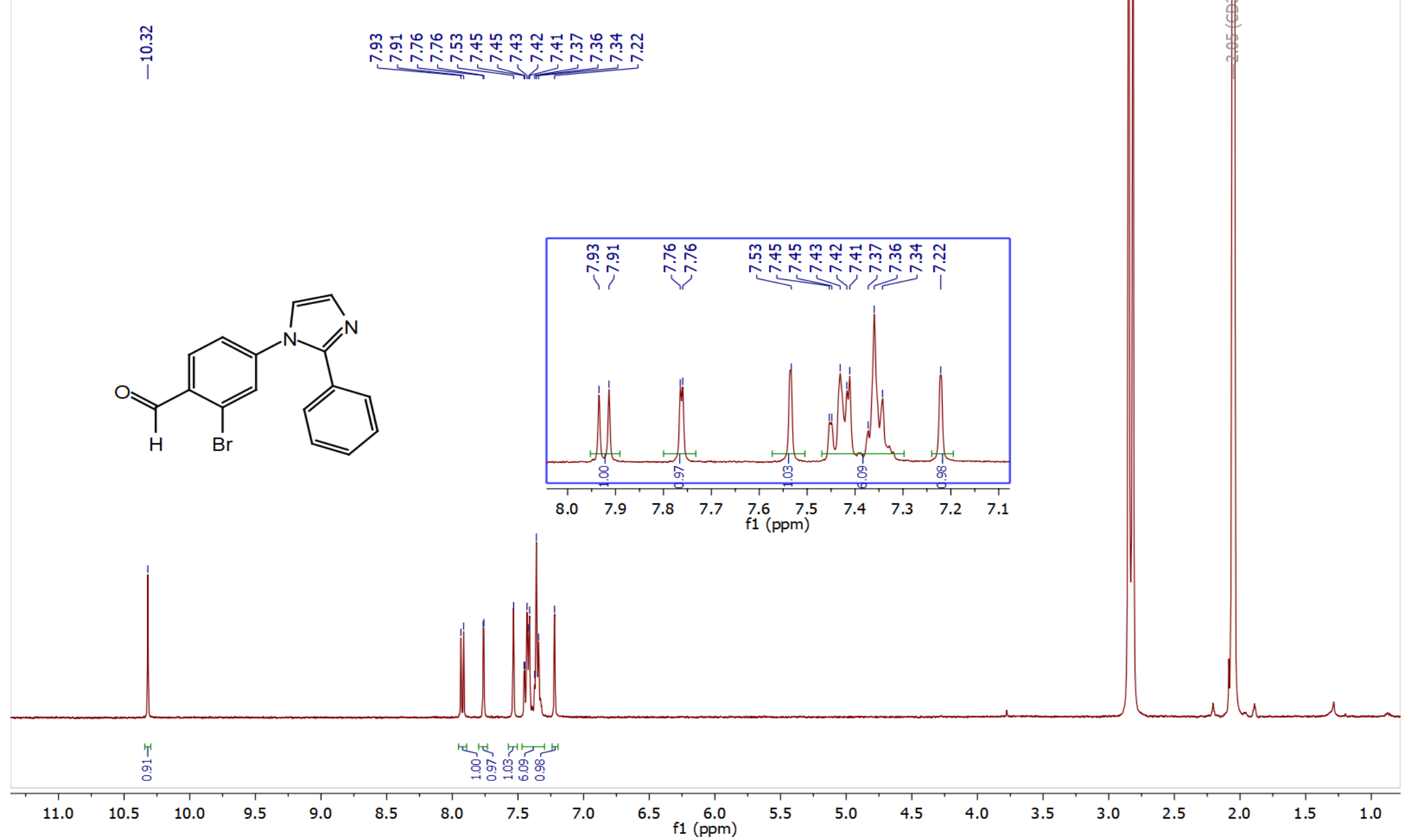



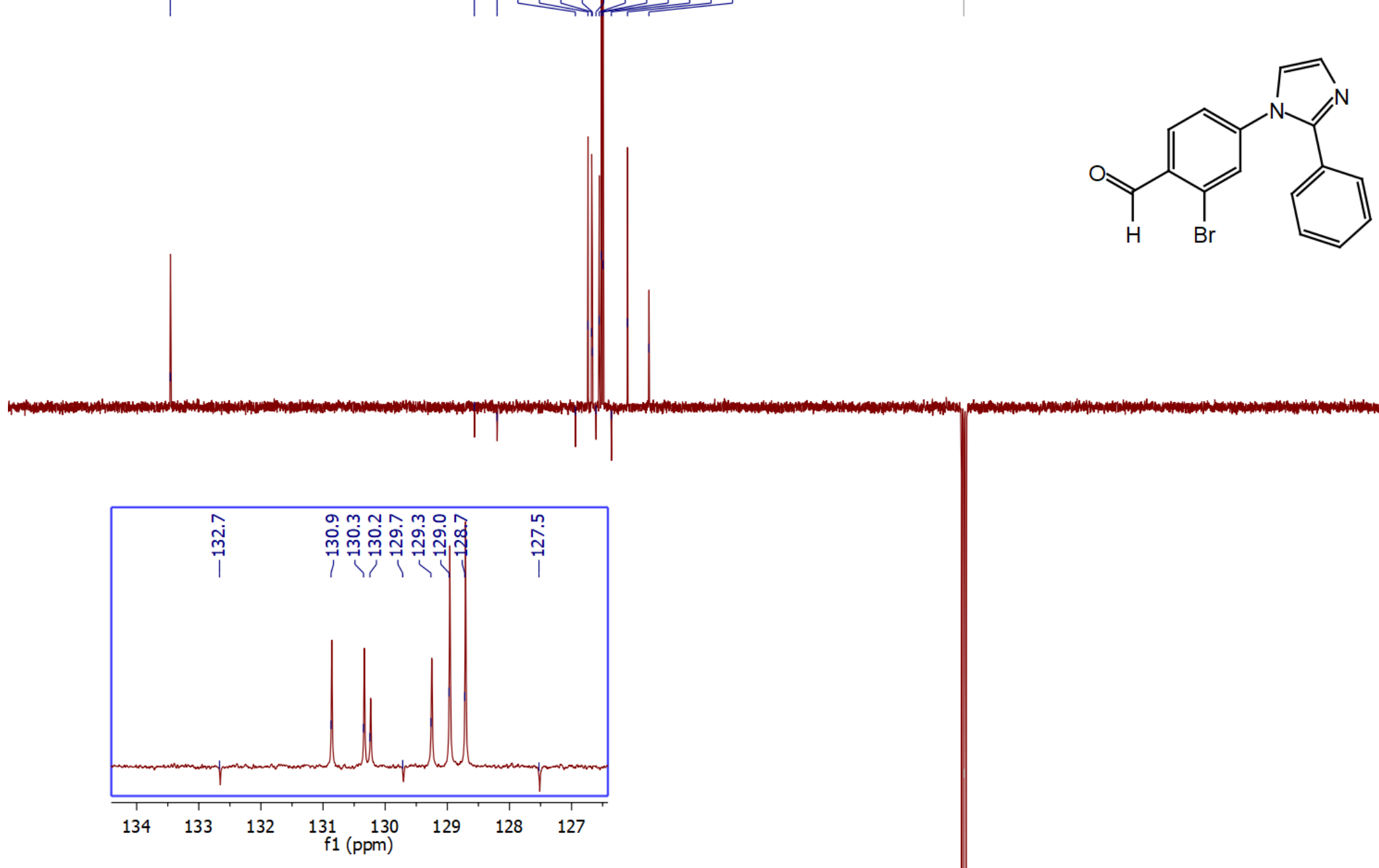


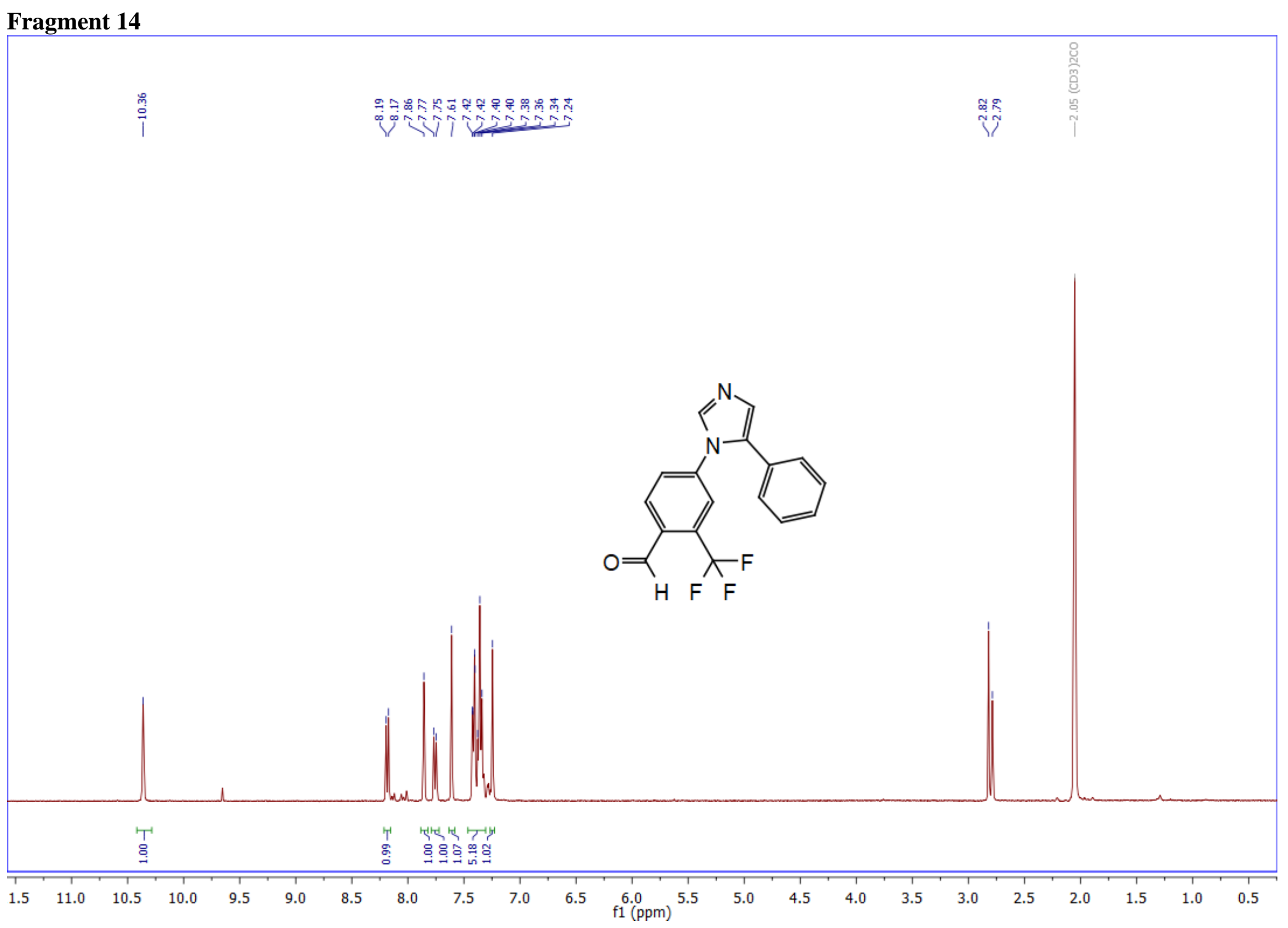


<smiles>O=Cc1ccc(-n2cncc2-c2ccccc2)cc1C(F)(F)F</smiles>

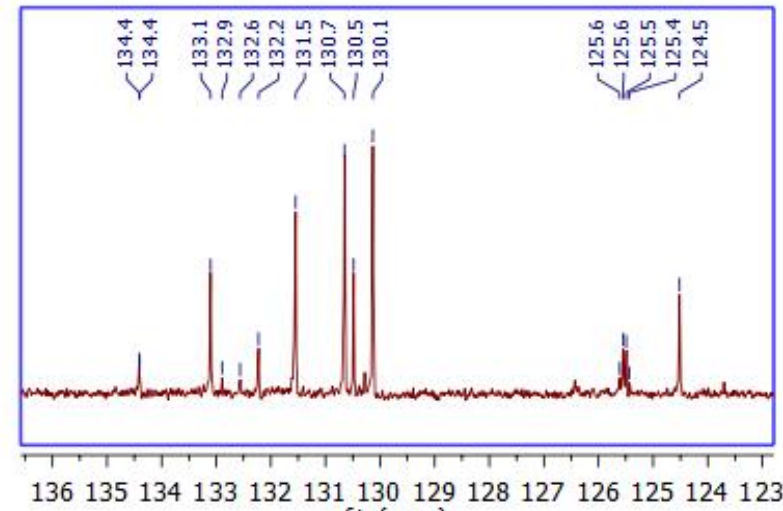

136135134133132131130129128127126125124123 $\mathrm{f} 1(\mathrm{ppm})$

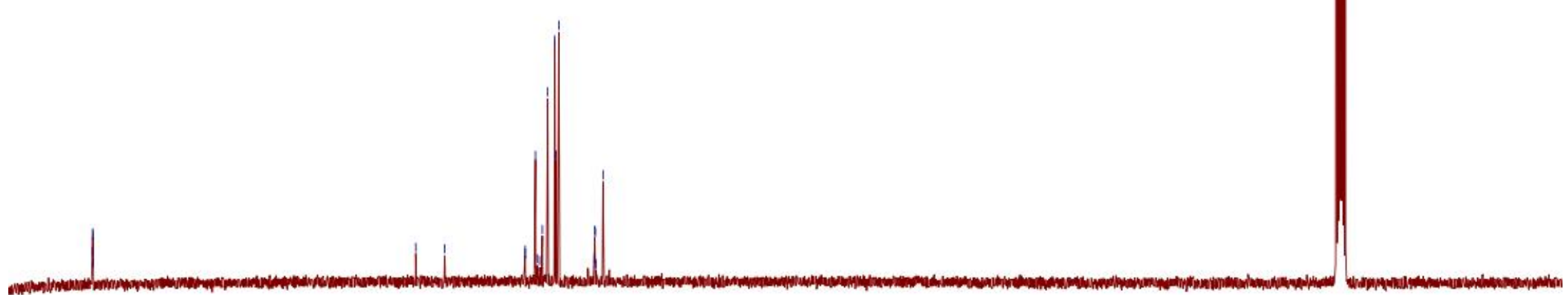

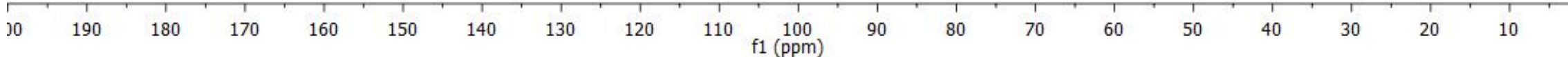


Fragment 15

LvD1014.1.fid
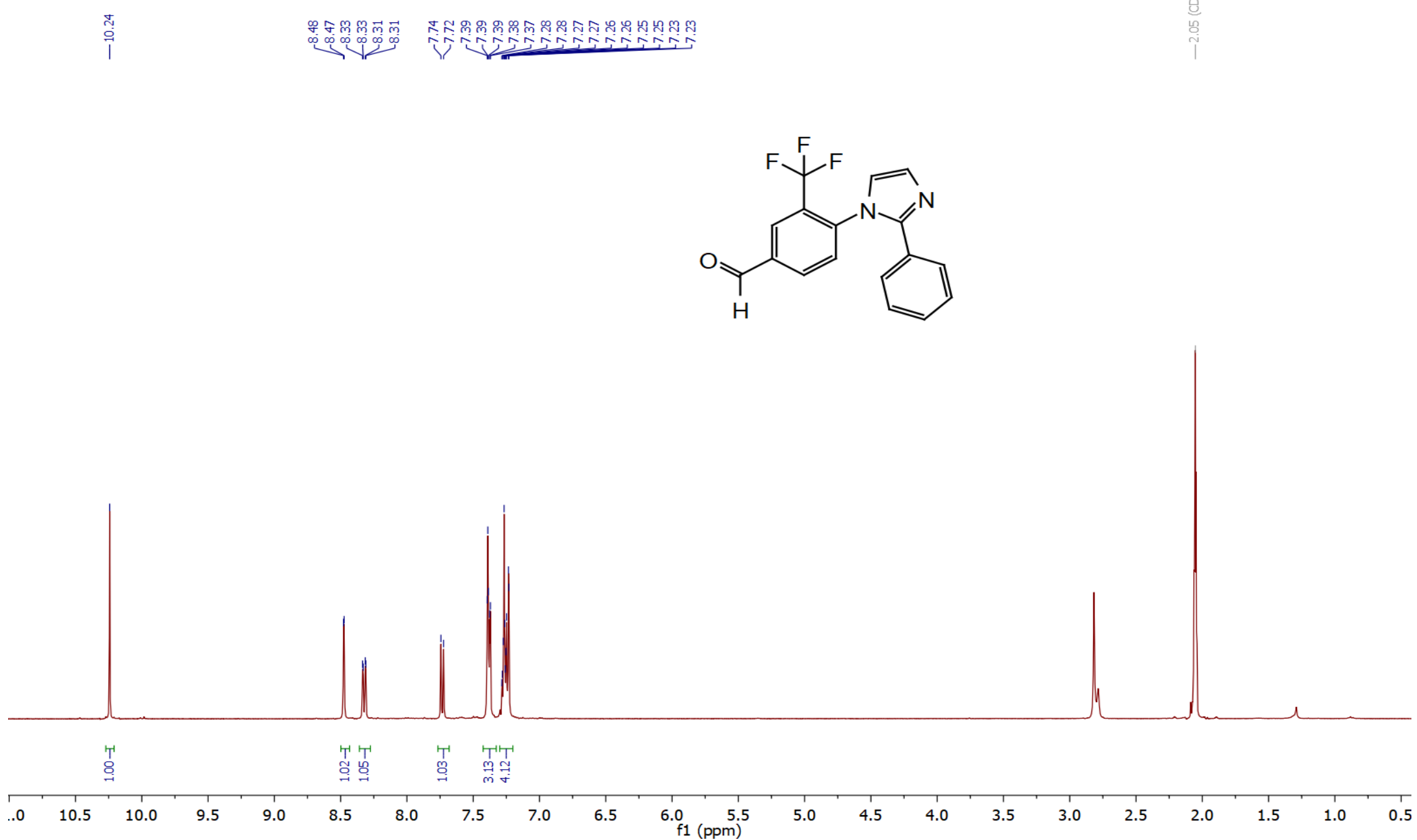

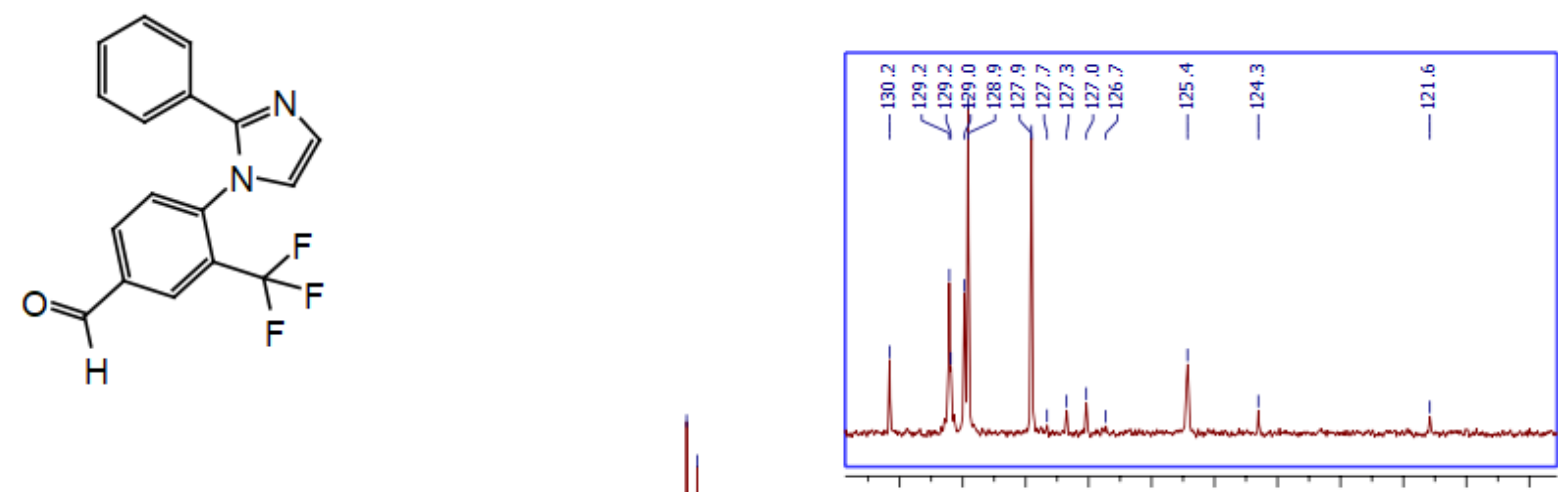

$\begin{array}{lllllllllll}130 & 129 & 128 & 127 & 126 & 125 & 124 & 123 & 122 & 121 & 120\end{array}$

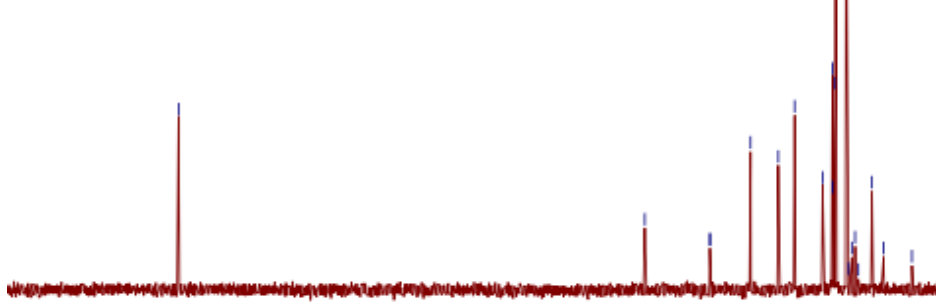


Fragment 16

LvD1019.1.fid
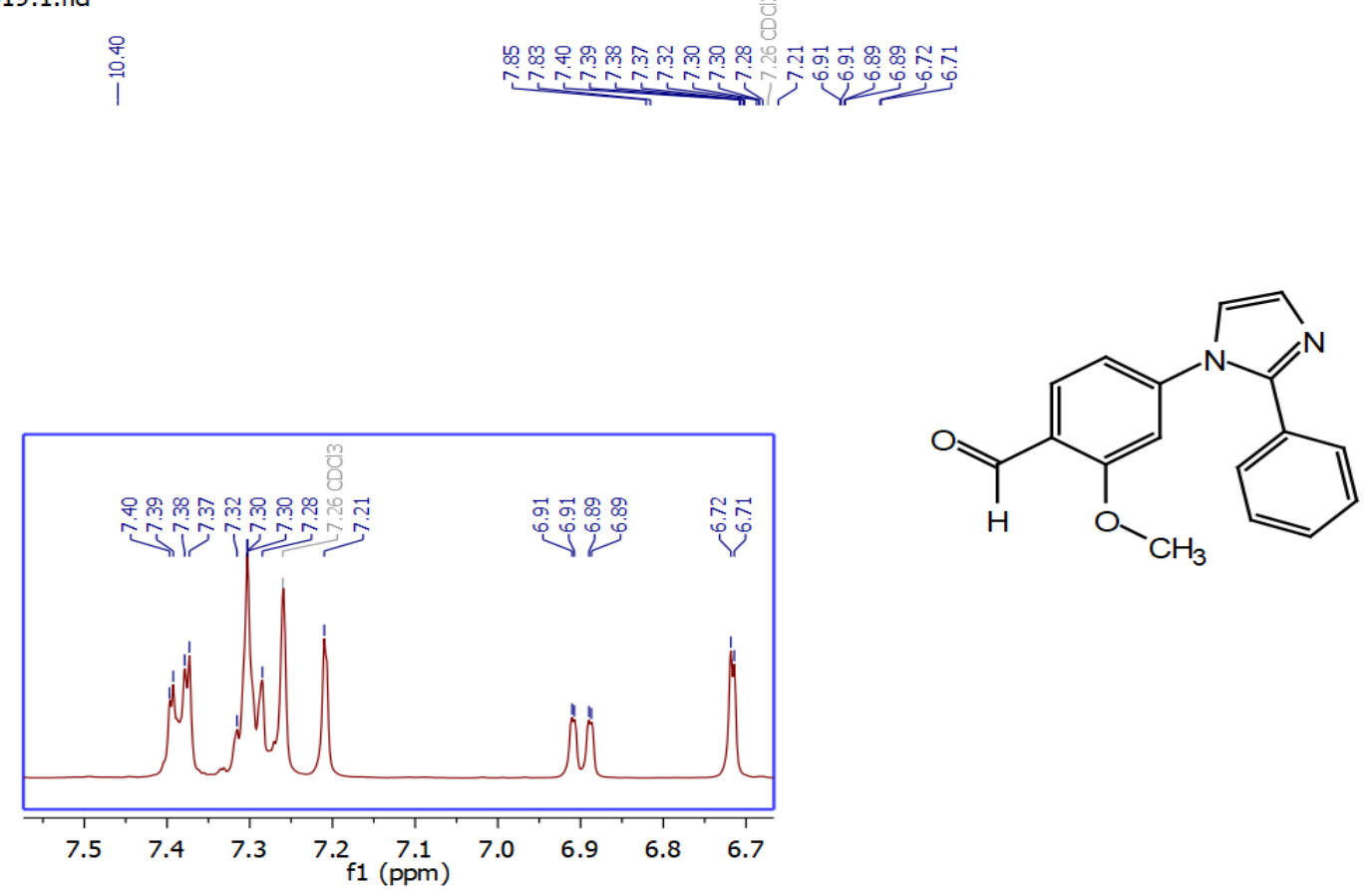

Acetone

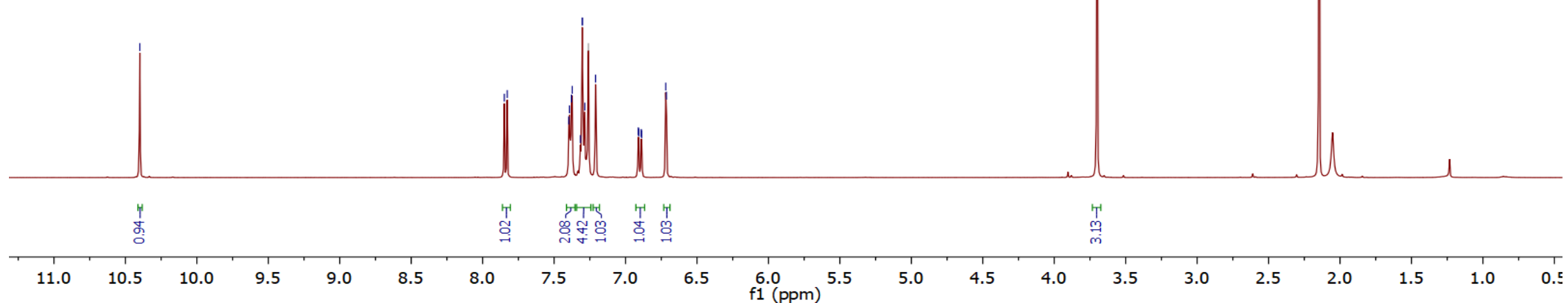



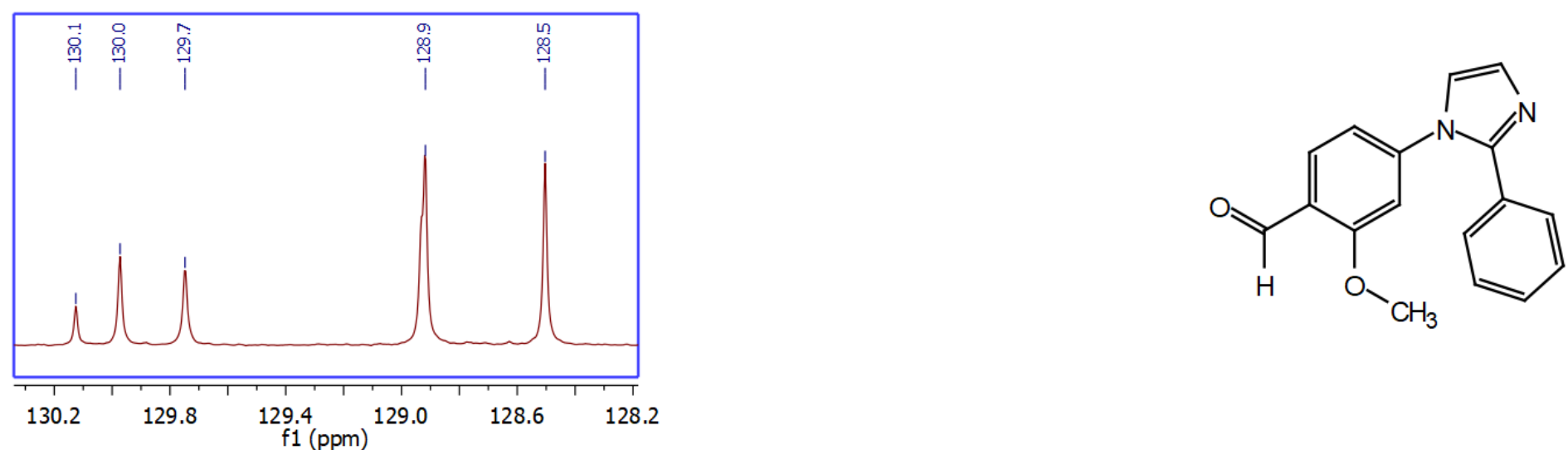

fi (ppm)

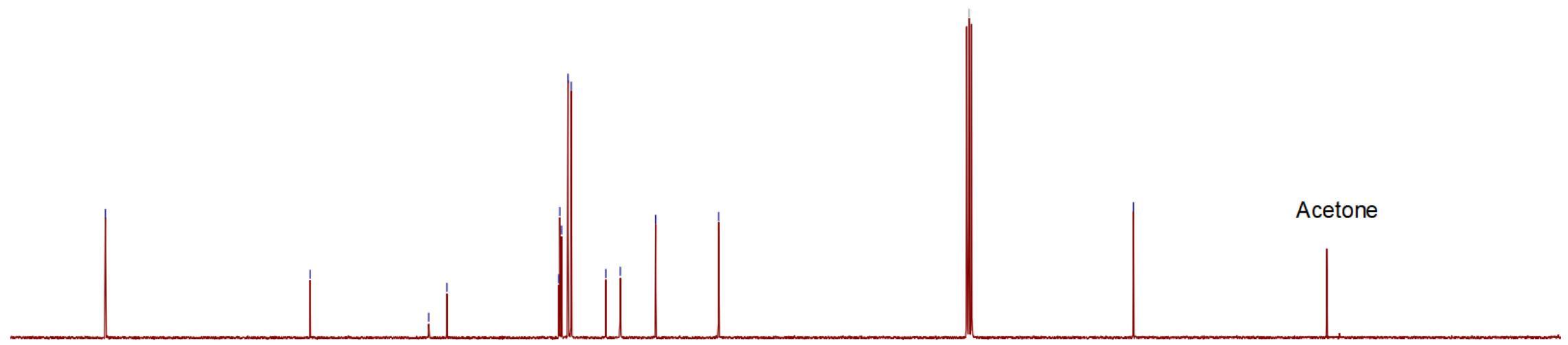

$00 \quad 190$ 
Fragment 17

LvD1012.1.fid
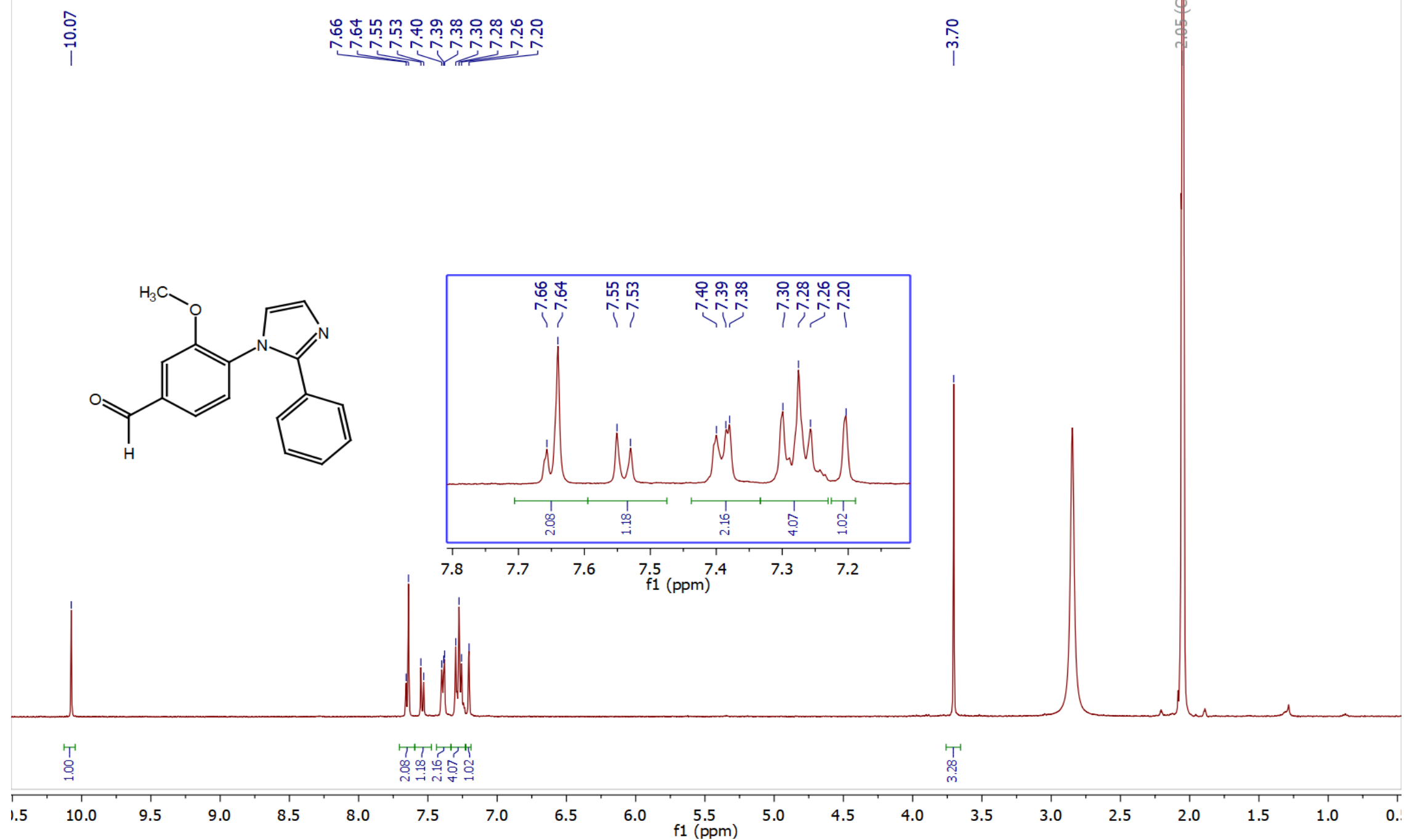

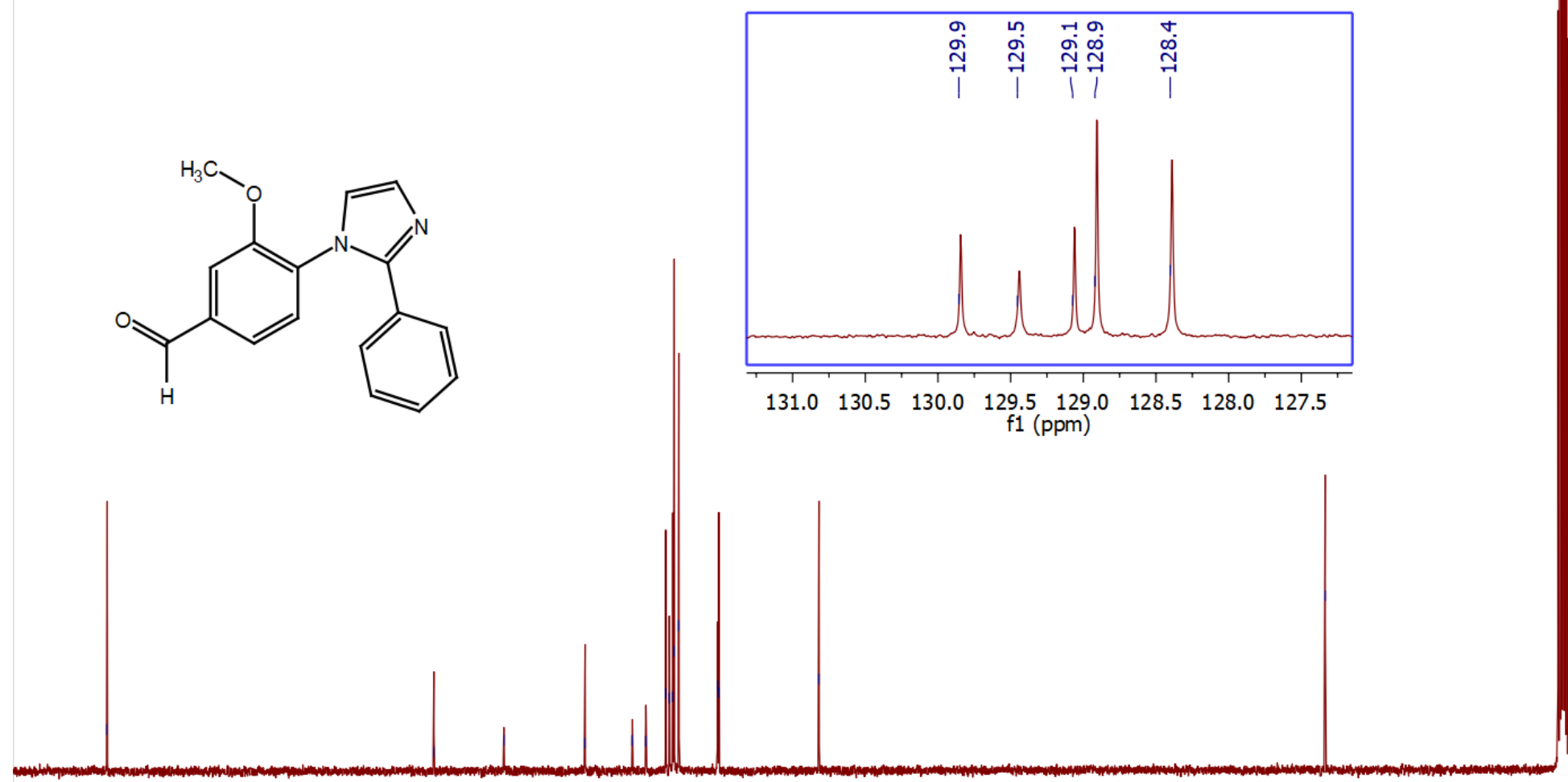
Fragment 18

LvD1016.1.fid

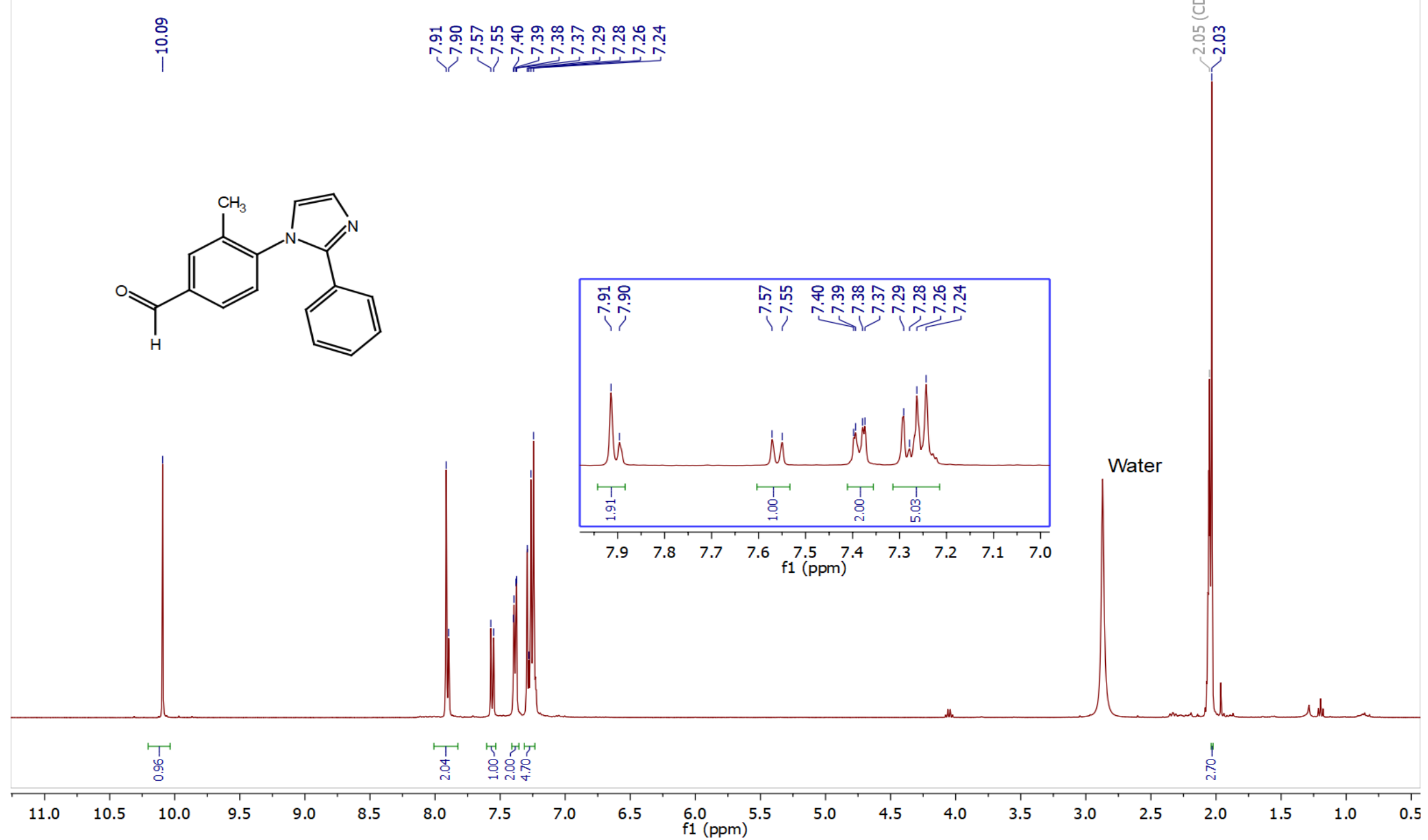



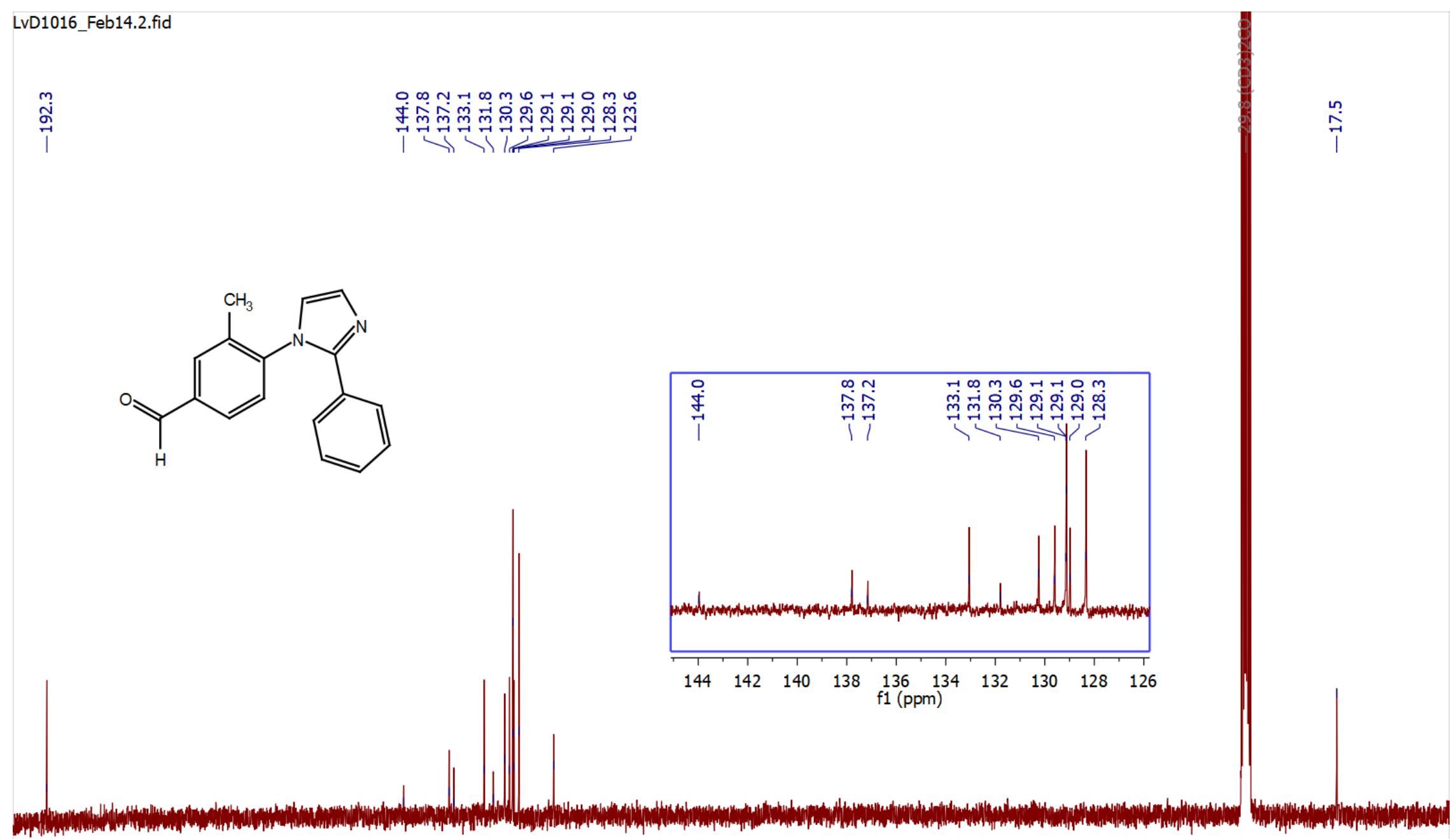

190

180

$170 \quad 160$

150

140

130

120

110

100

$90 \quad 80$

80

60

50

40

30 $20 \quad 10$ 
Fragment 19

LvD1032.10.fid

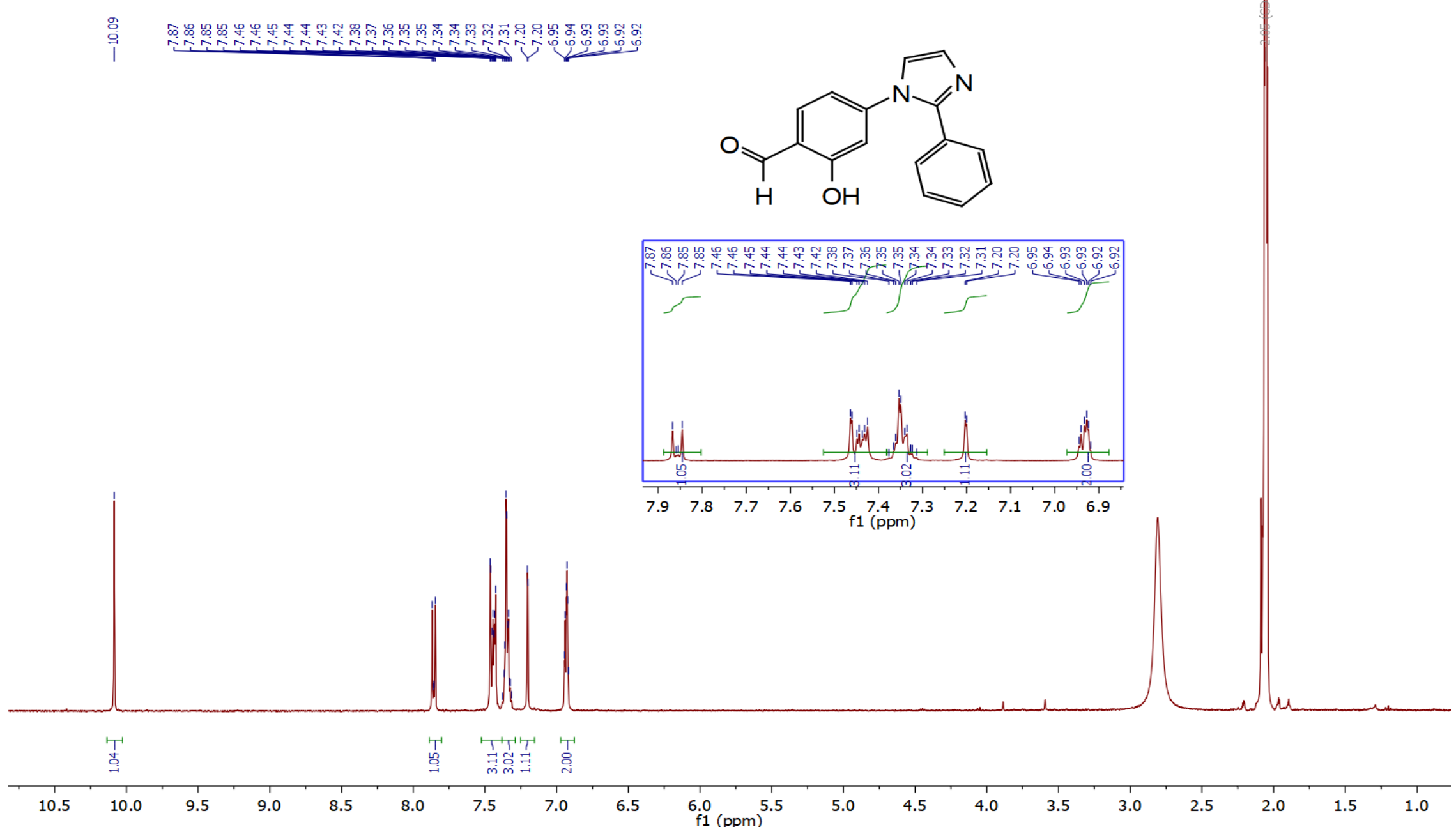


LvD1032.11.fid

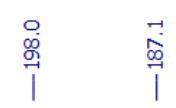
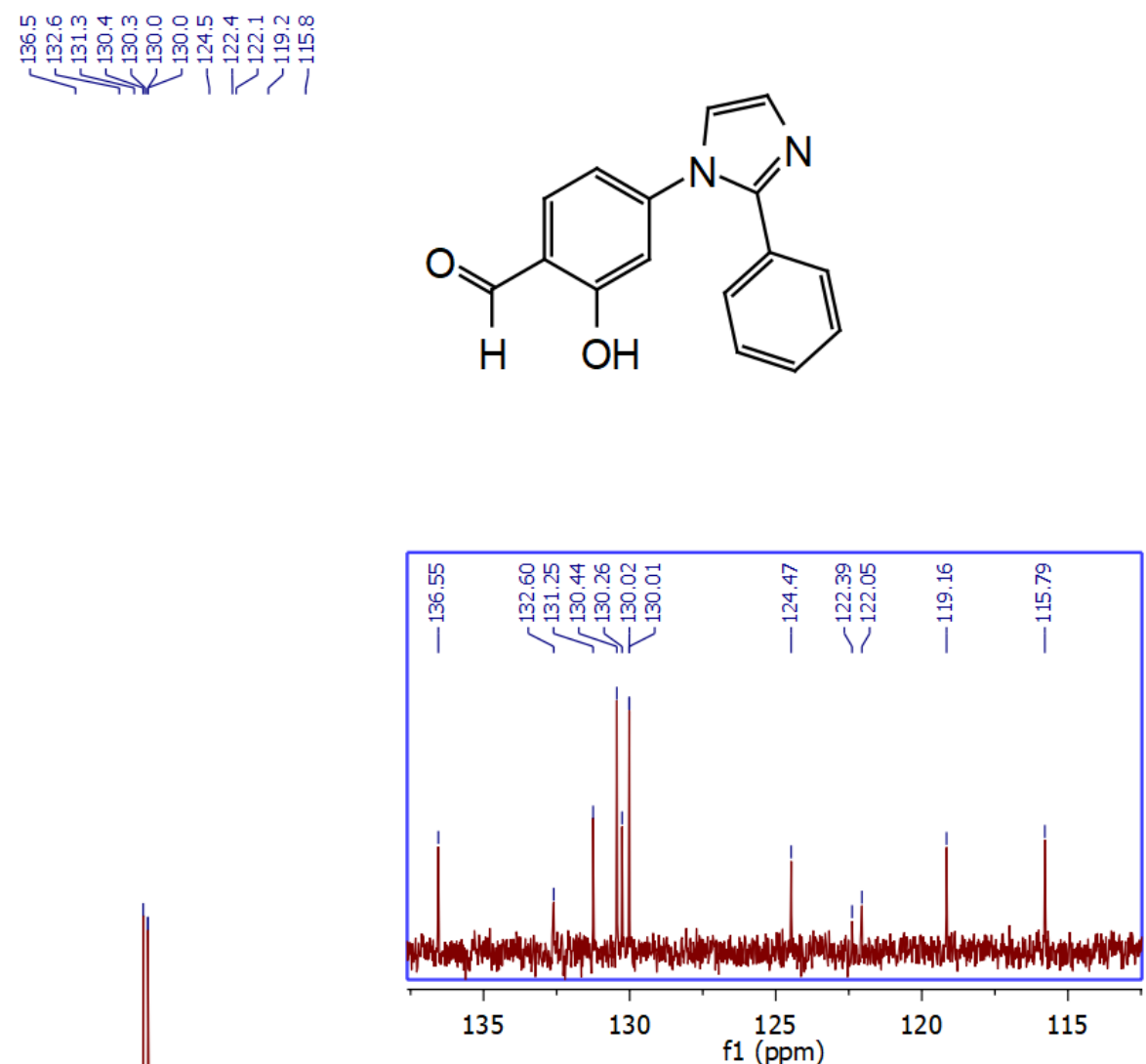

$\mid$

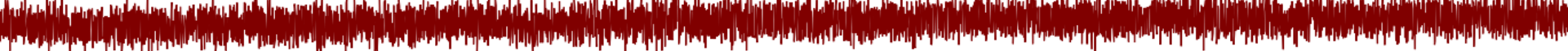


Fragment 20

LvD1021.1.fid

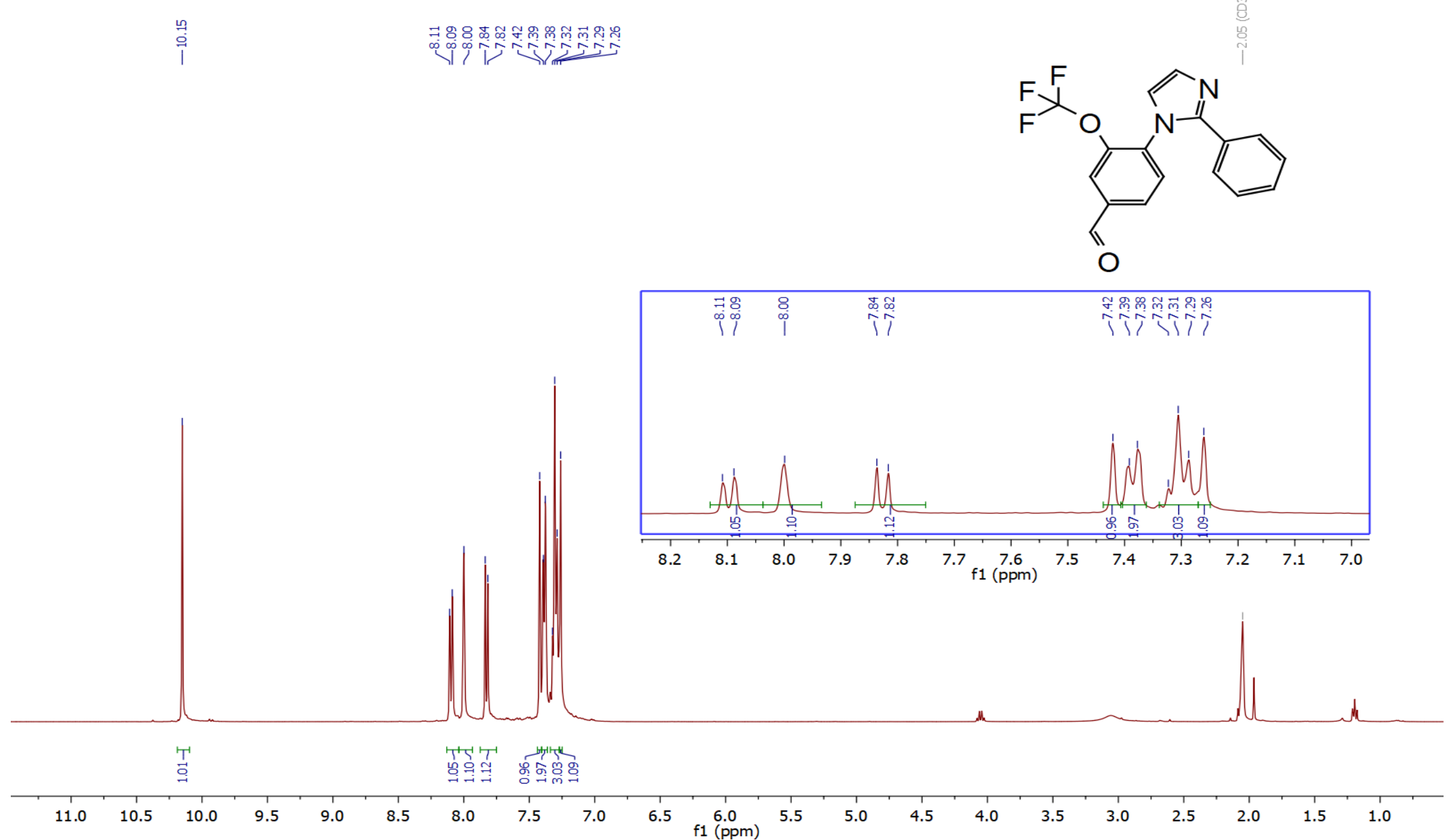




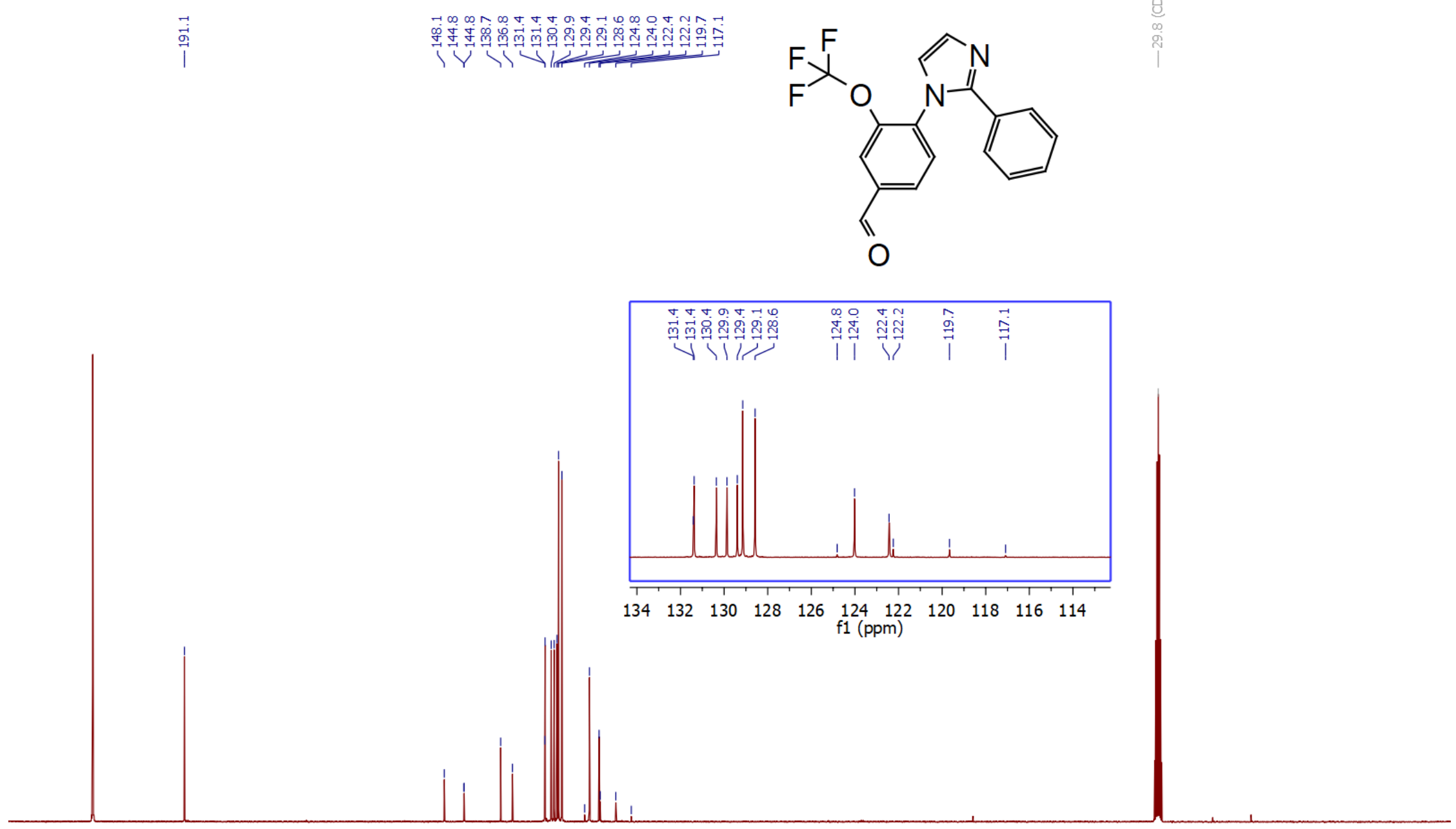

$\begin{array}{lllllllllllllllllllllllllll}20 & 210 & 200 & 190 & 180 & 170 & 160 & 150 & 140 & 130 & 120 & 110 & 100 & 90 & 80 & 70 & 60 & 50 & 40 & 30 & 20 & 10 & 0 & -10 & 0\end{array}$ 
Fragment 21

LvD1020.1.fid

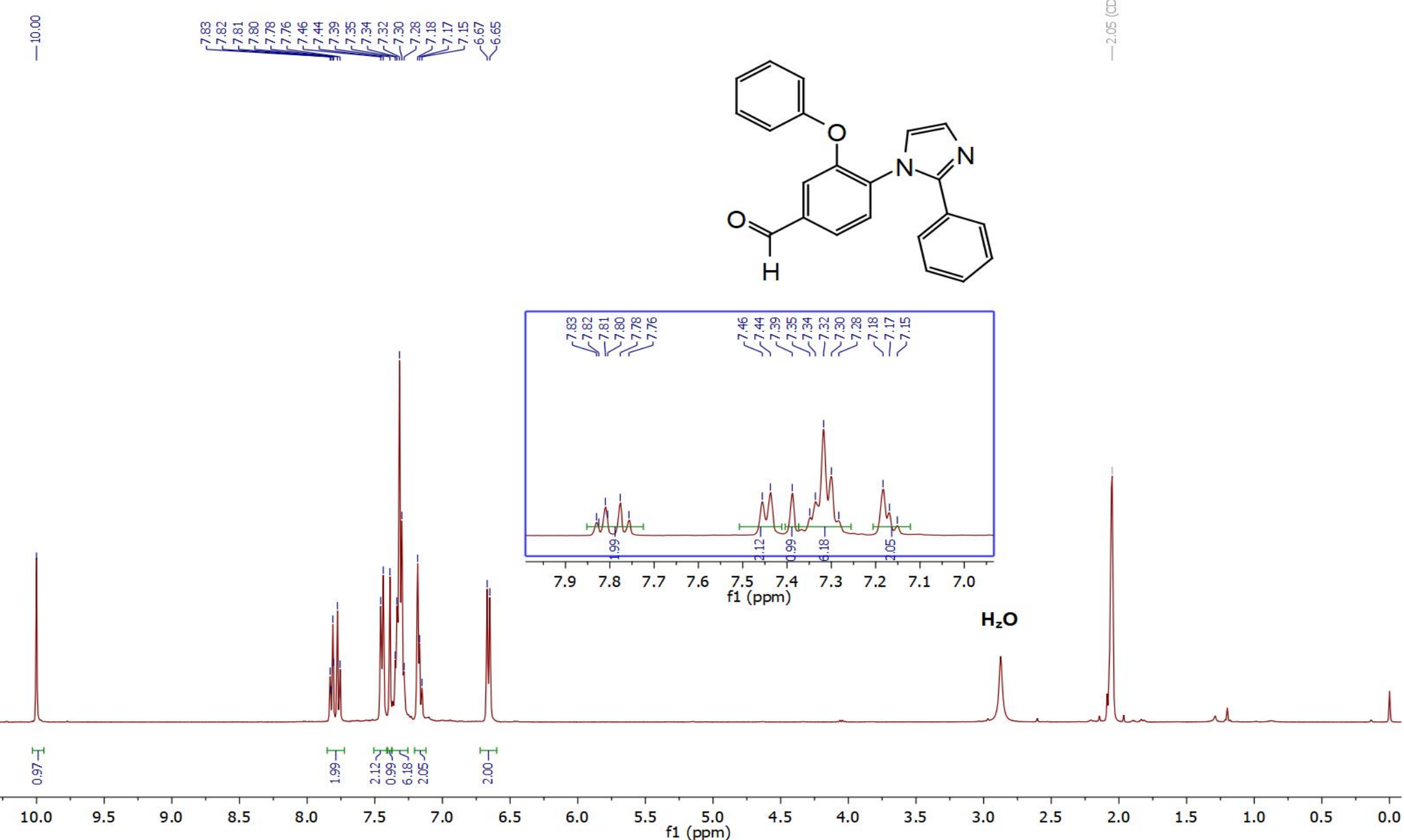


LvD1020.2.fid
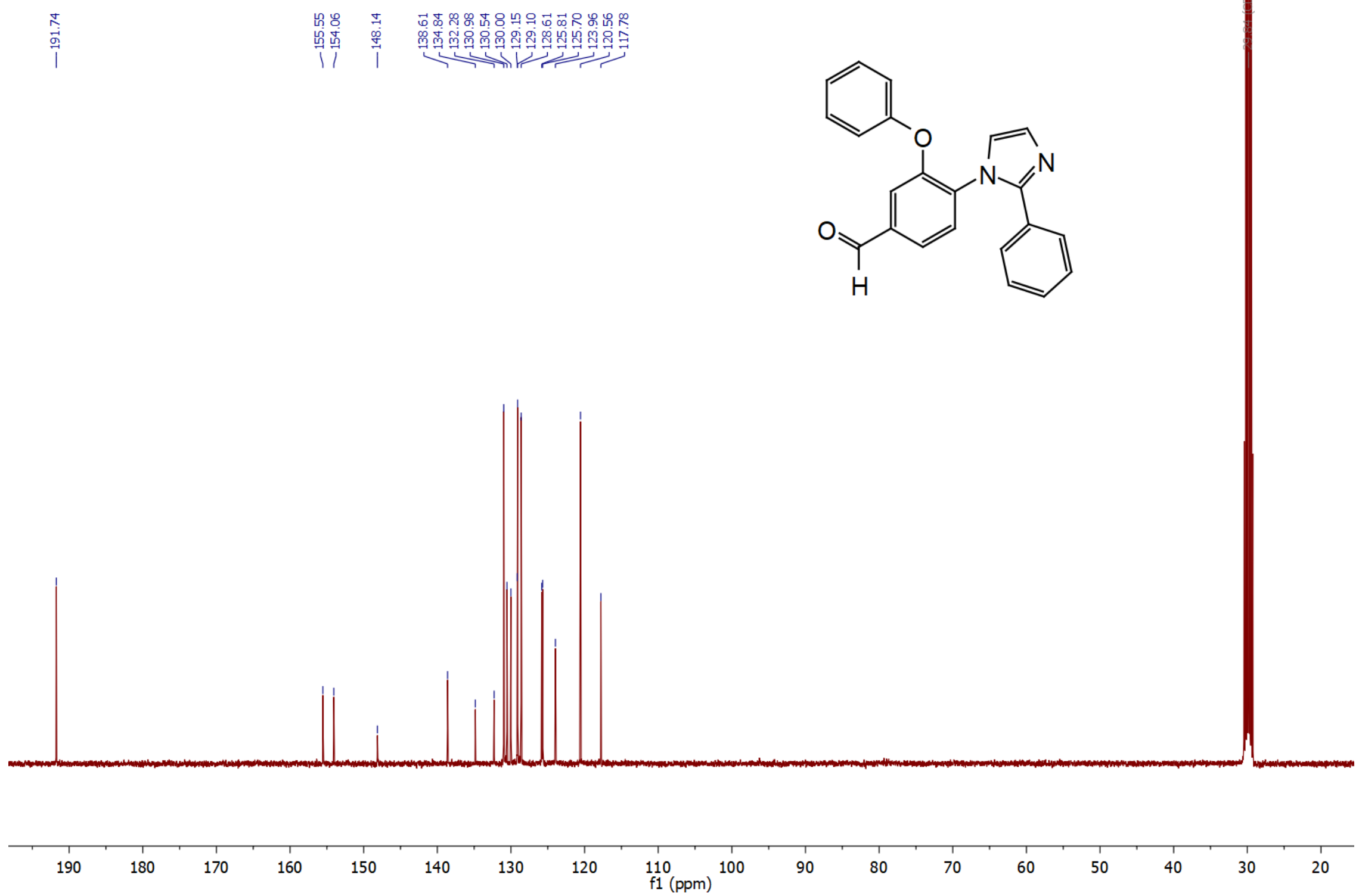
Fragment 22

LvD1011.1.fid

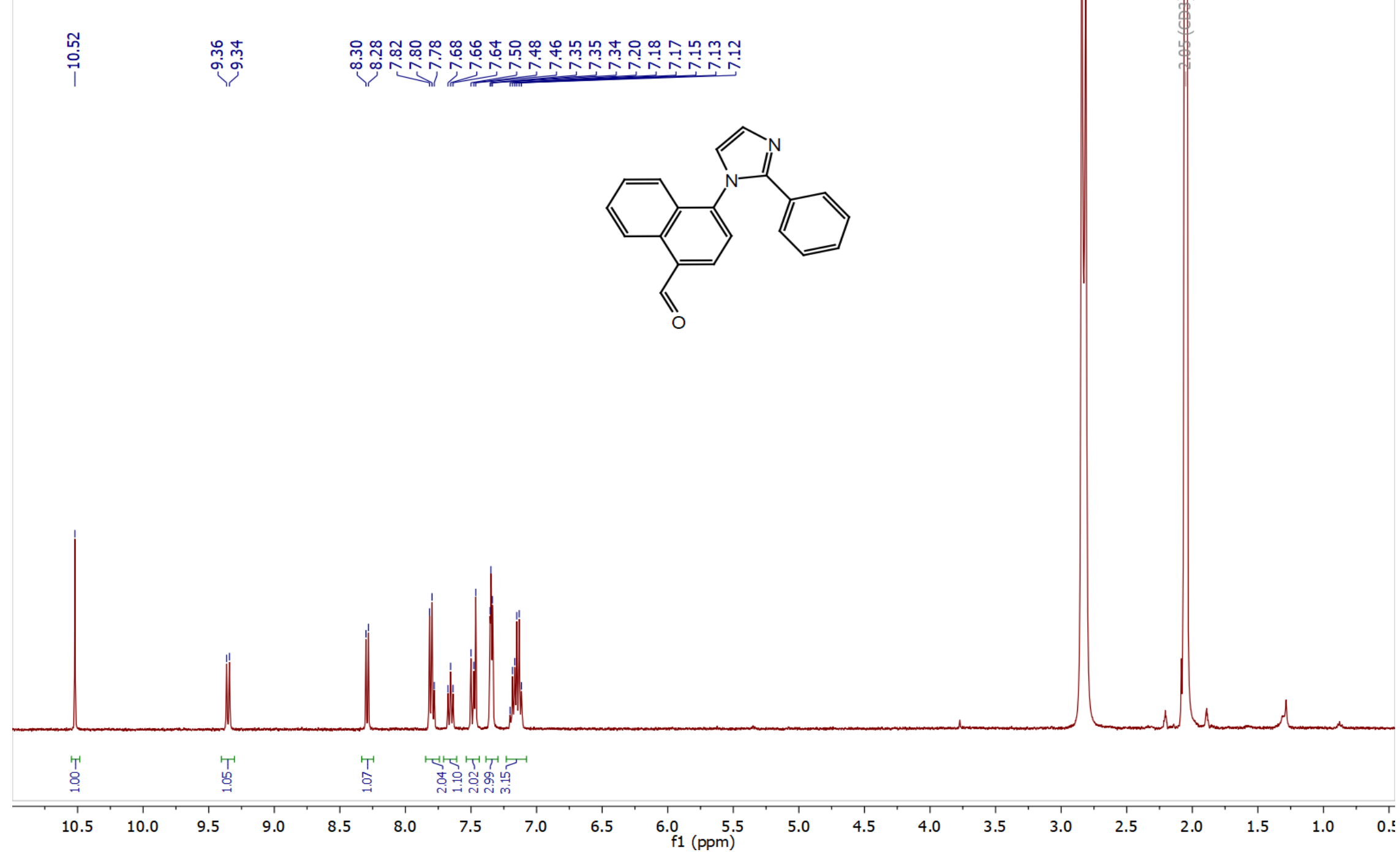




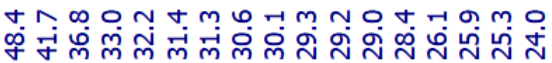

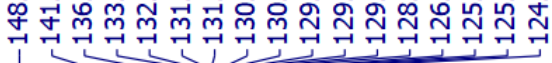

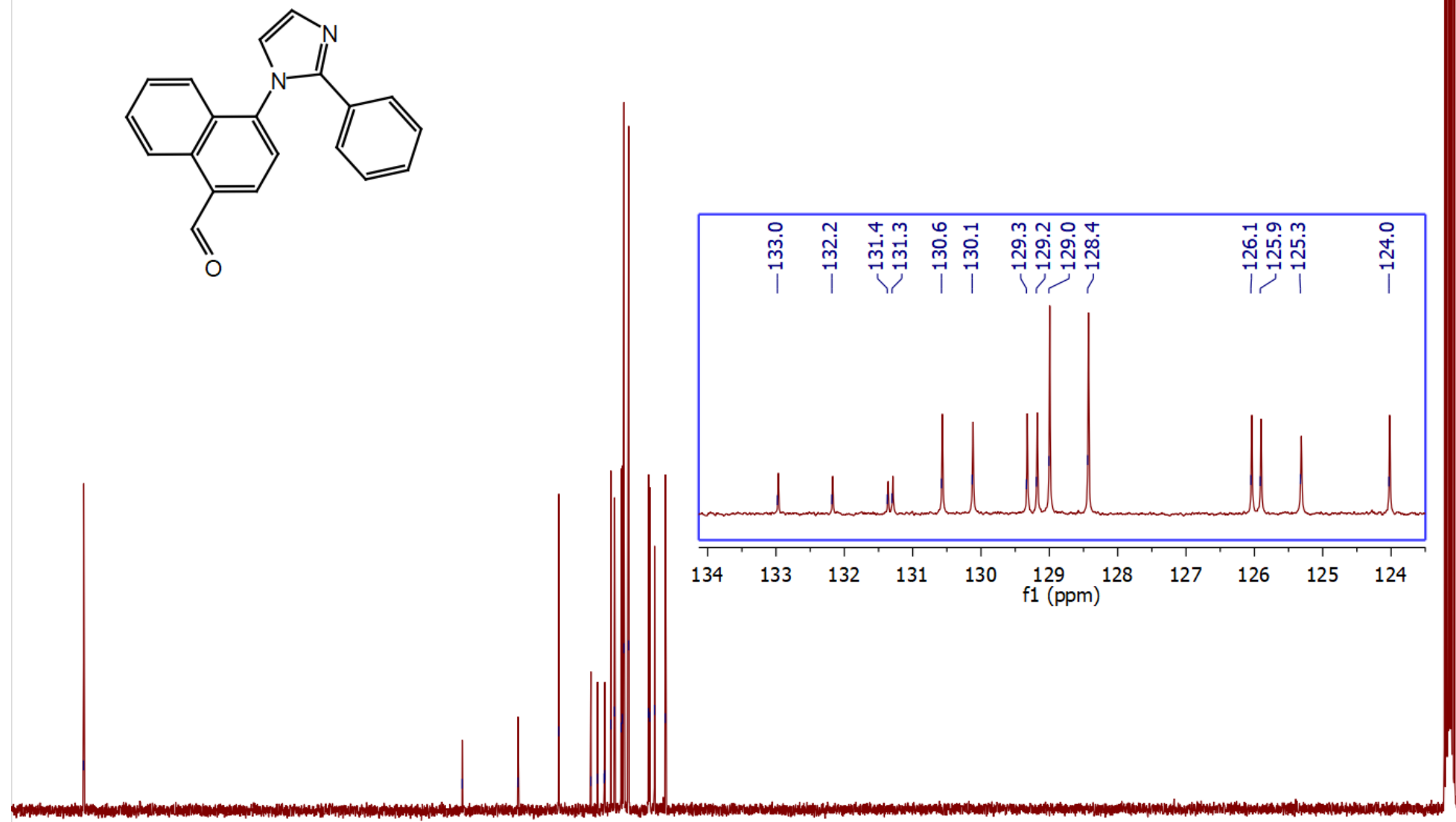

200

$190 \quad 180$

160

150

$110 \quad 100$

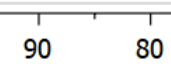

$80+70$

60

$50 \quad 40$

30

10 
Fragment 23

PC2046 FC.1.fid

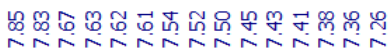
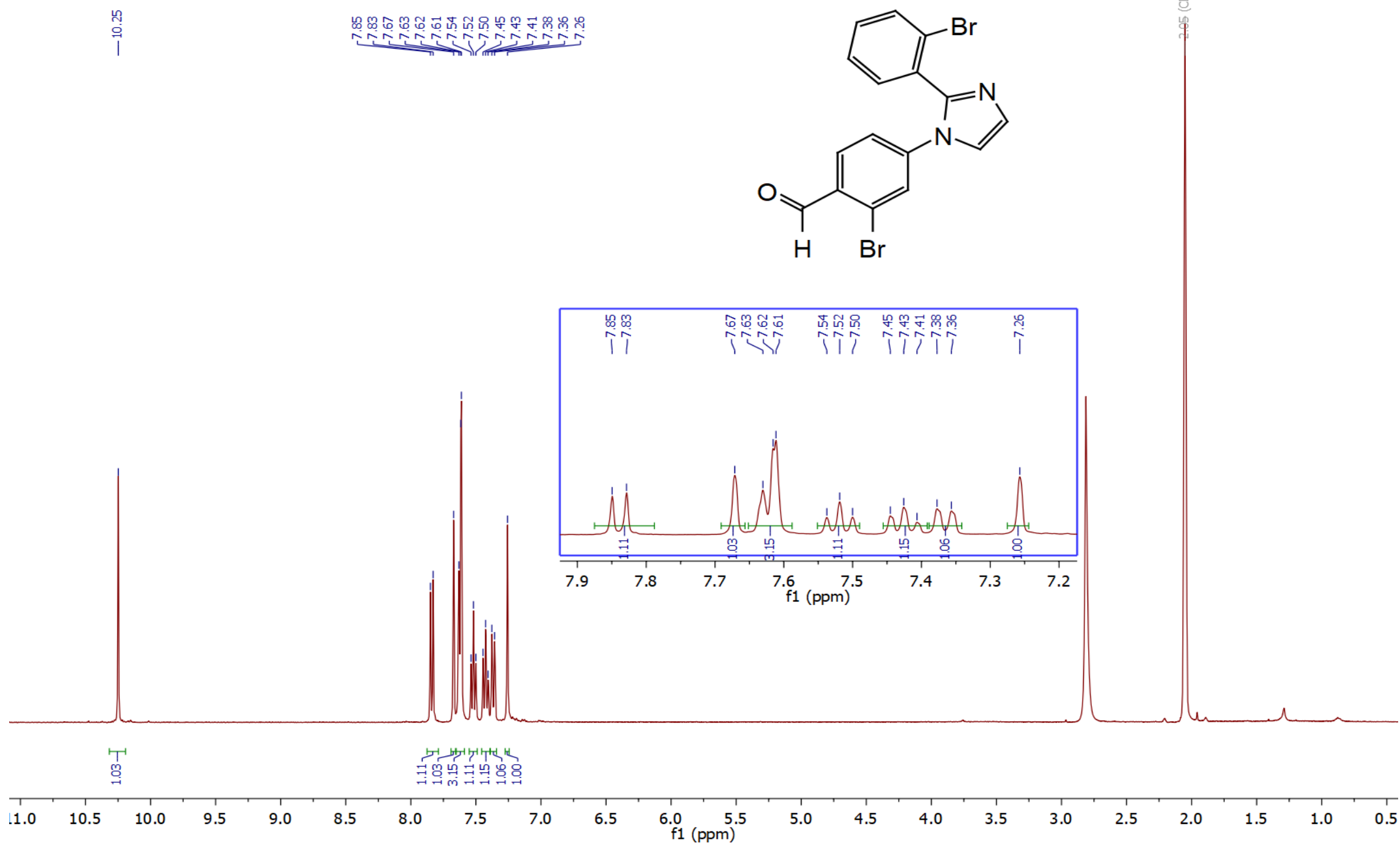
PC2046_FC.2.fid

$\stackrel{\infty}{\stackrel{0}{0}}$

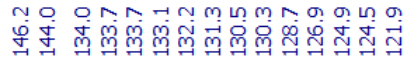

|
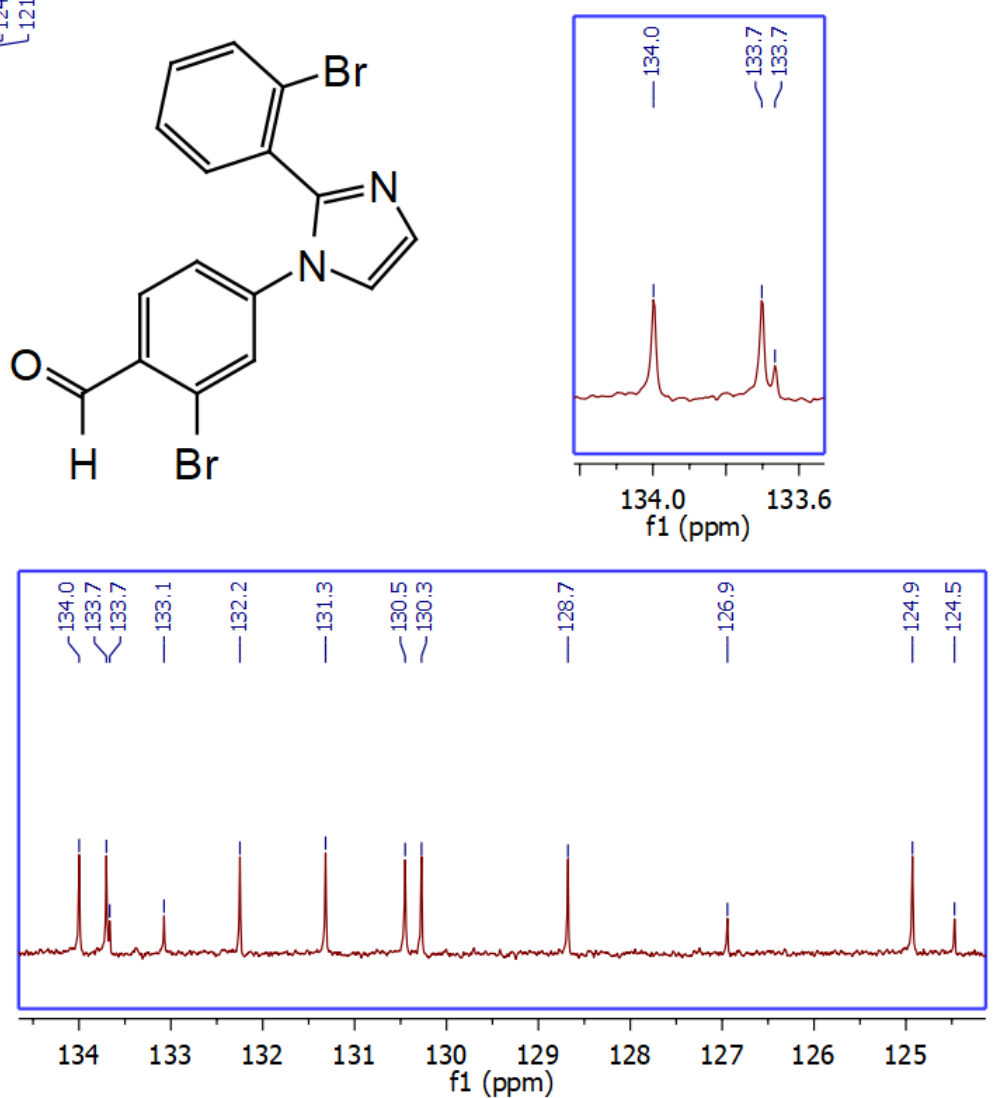

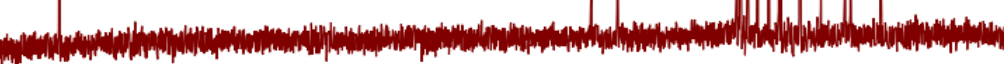

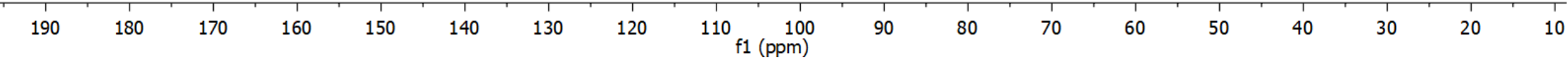


Fragment 24

PC2048A_FC.1.fid

$\stackrel{\mathscr{m}}{\stackrel{1}{1}}$

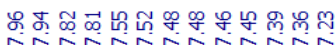

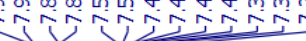
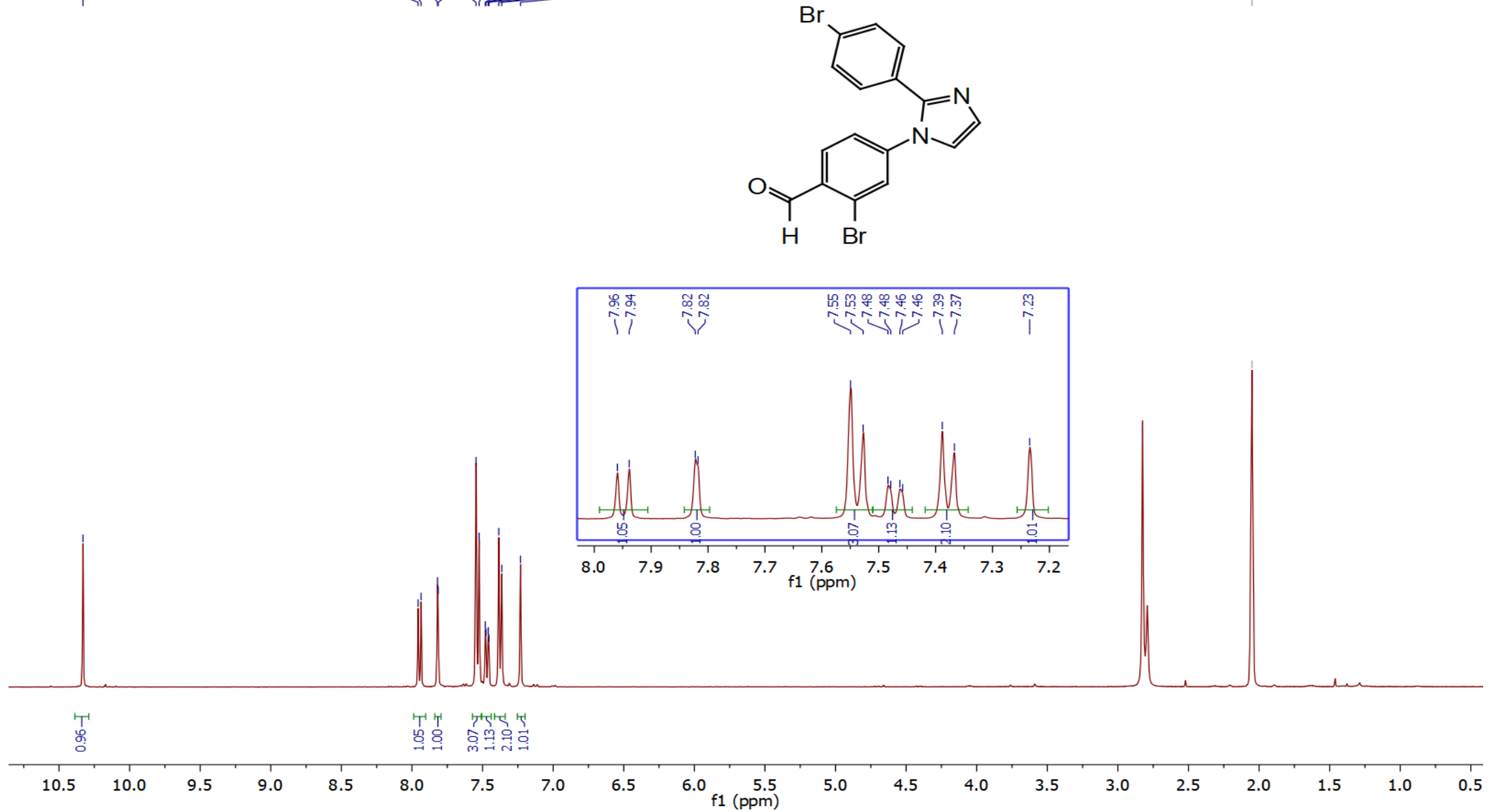
PC2048A_FC.2.fid
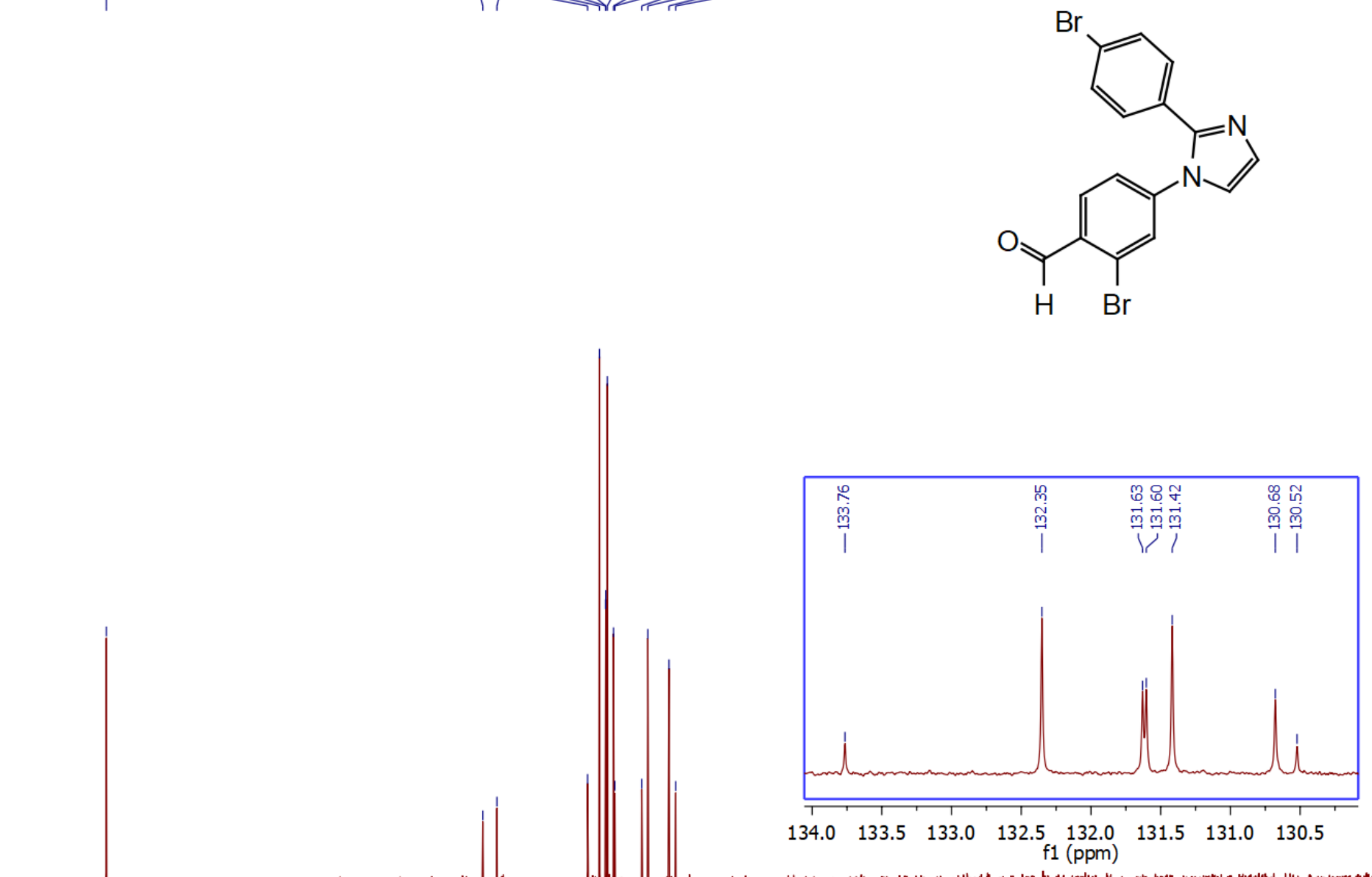
Fragment 25

PC2048B_FC.1.fid

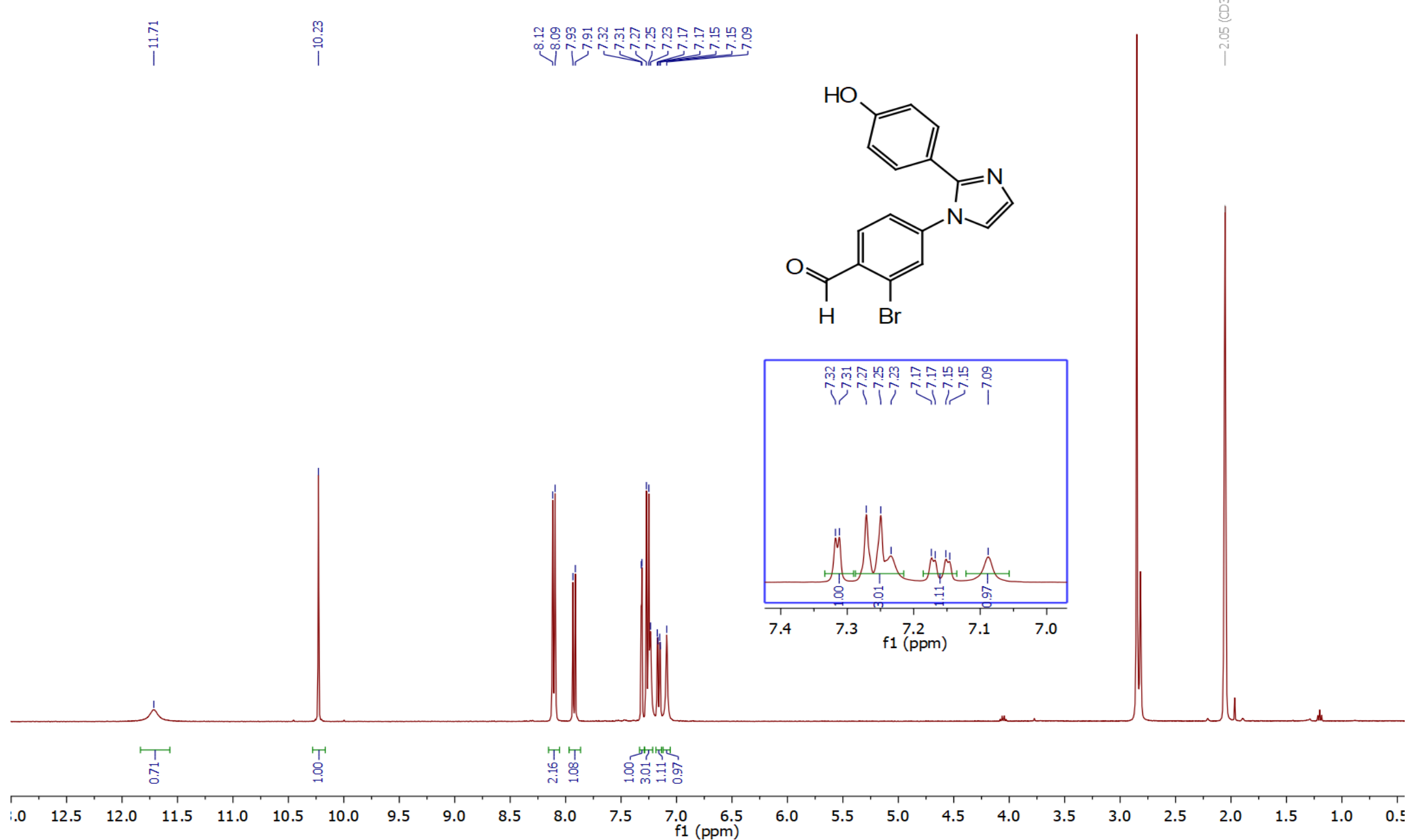


PC2048B_FC.2.fid

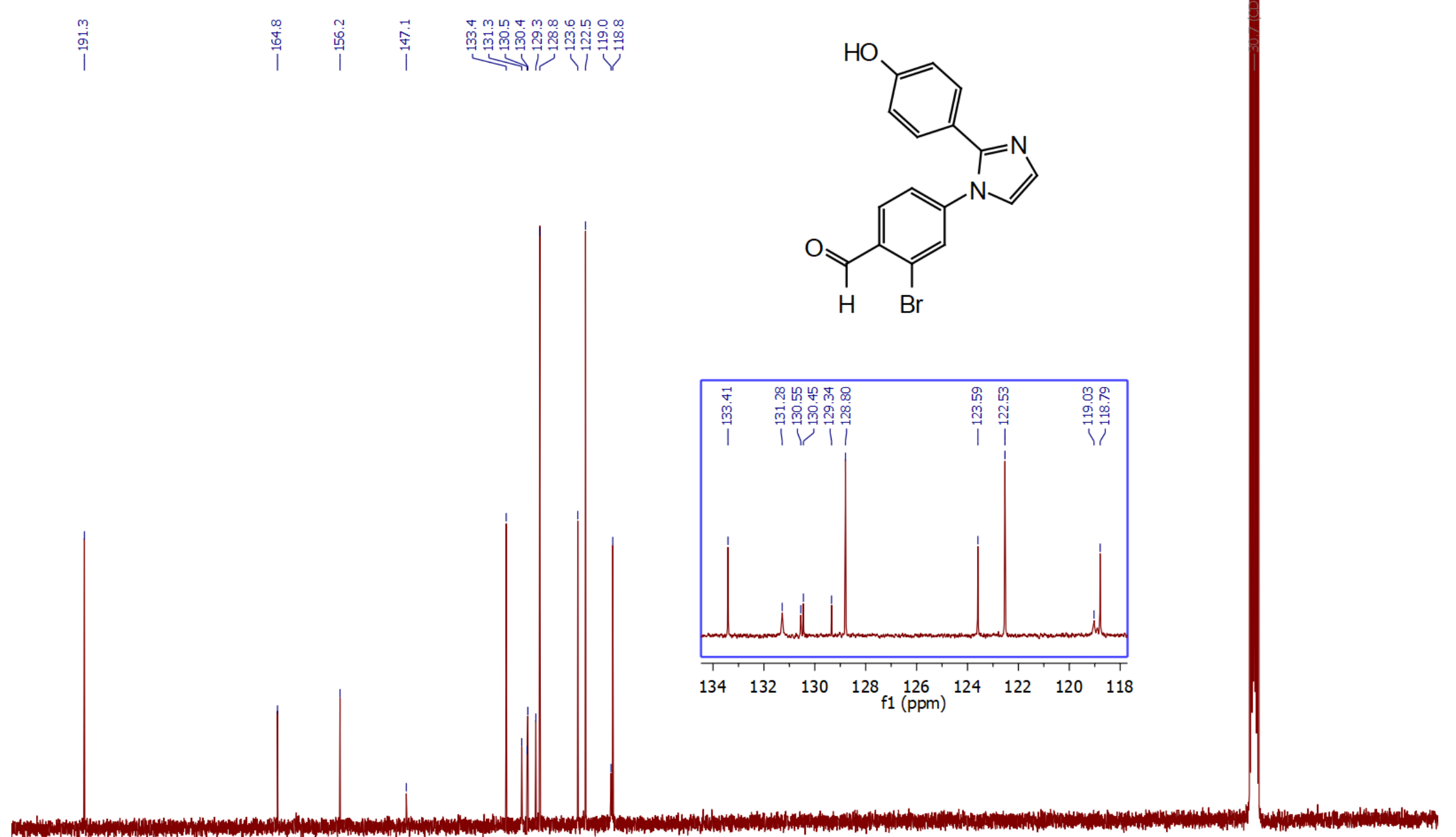


Fragment 26

PC2048C_FC.1.fid

1

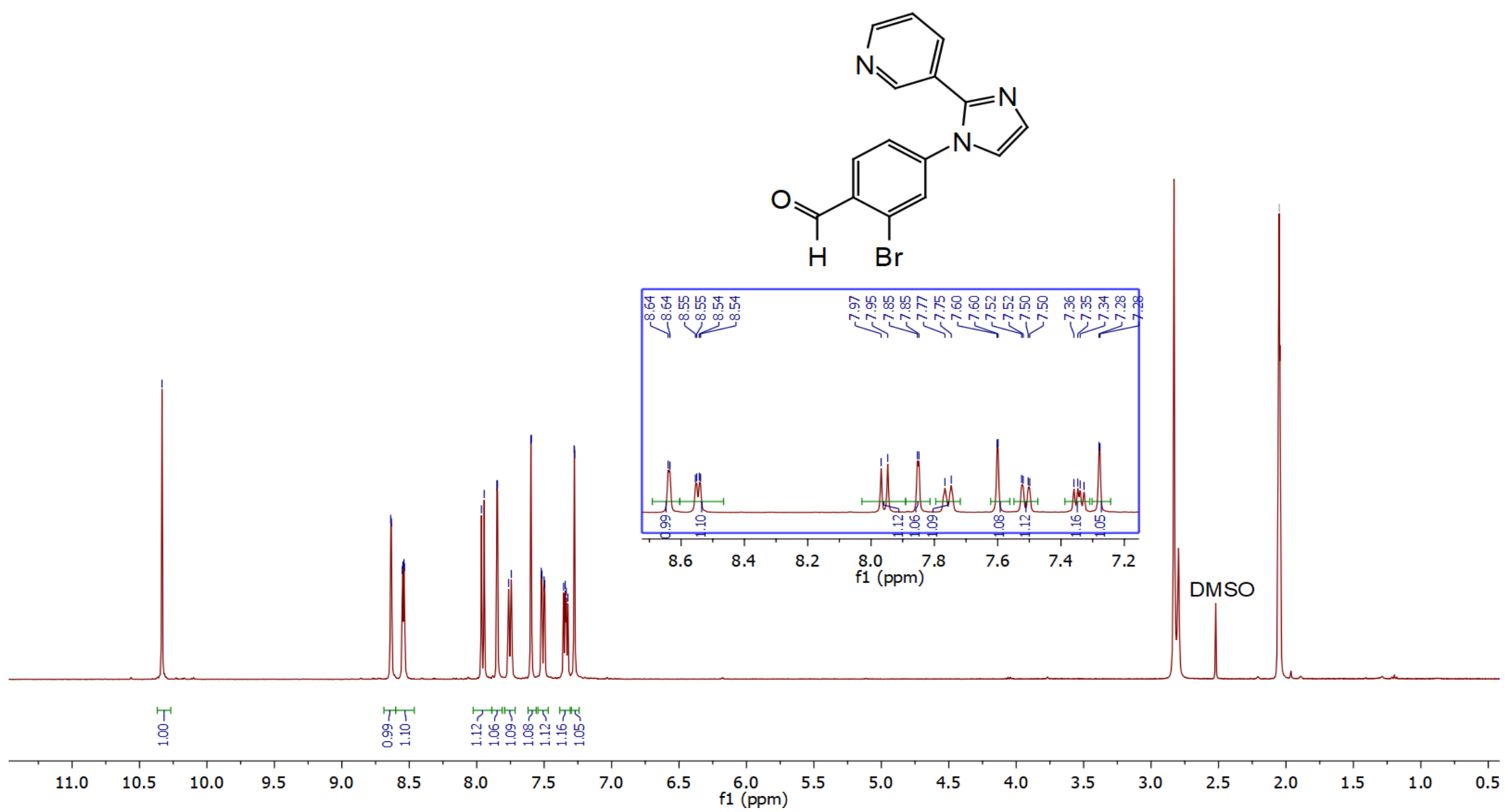




\section{Fragment 27}

1
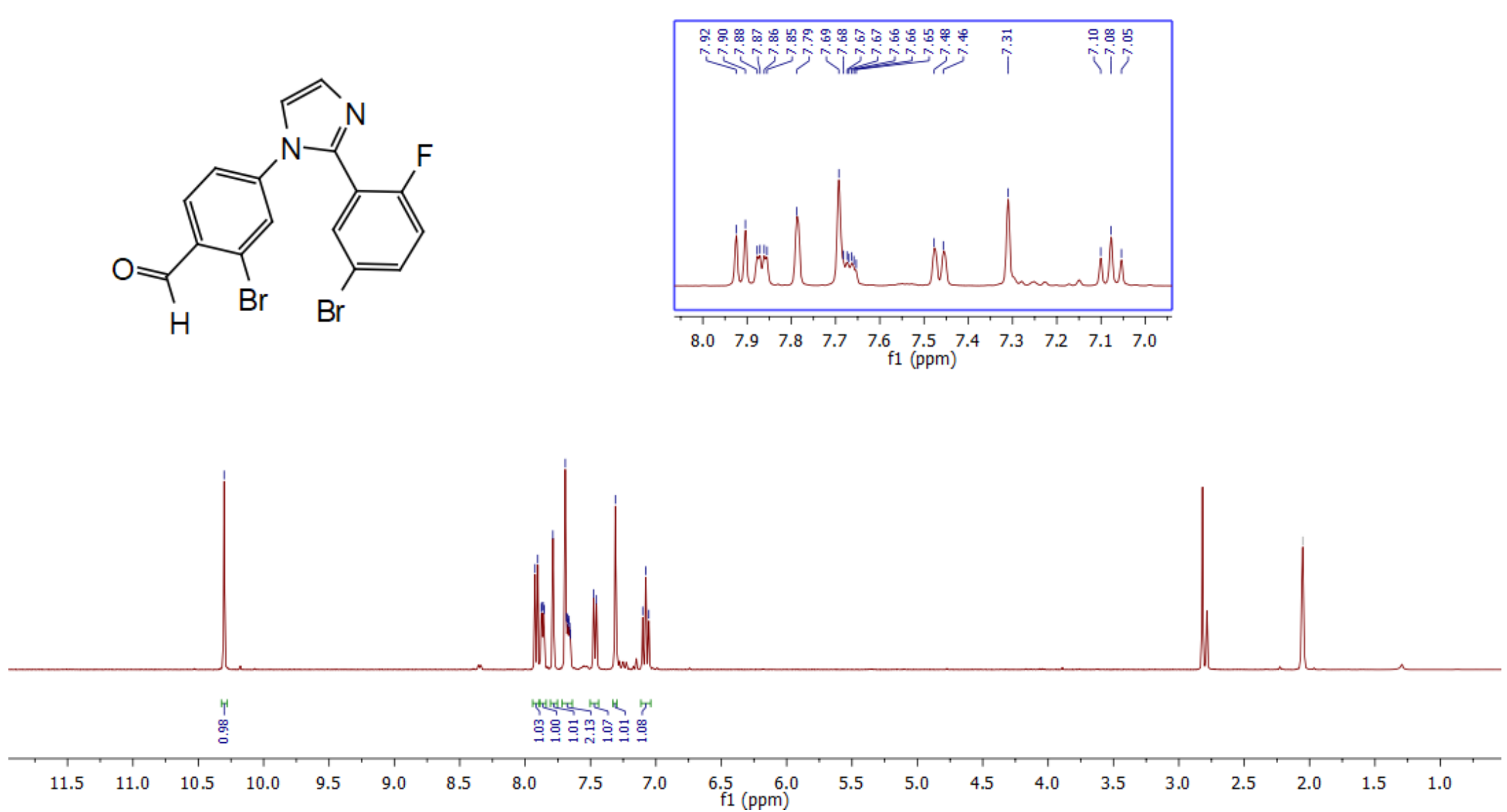


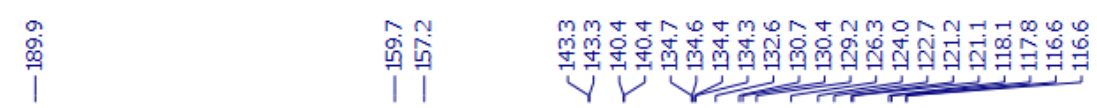
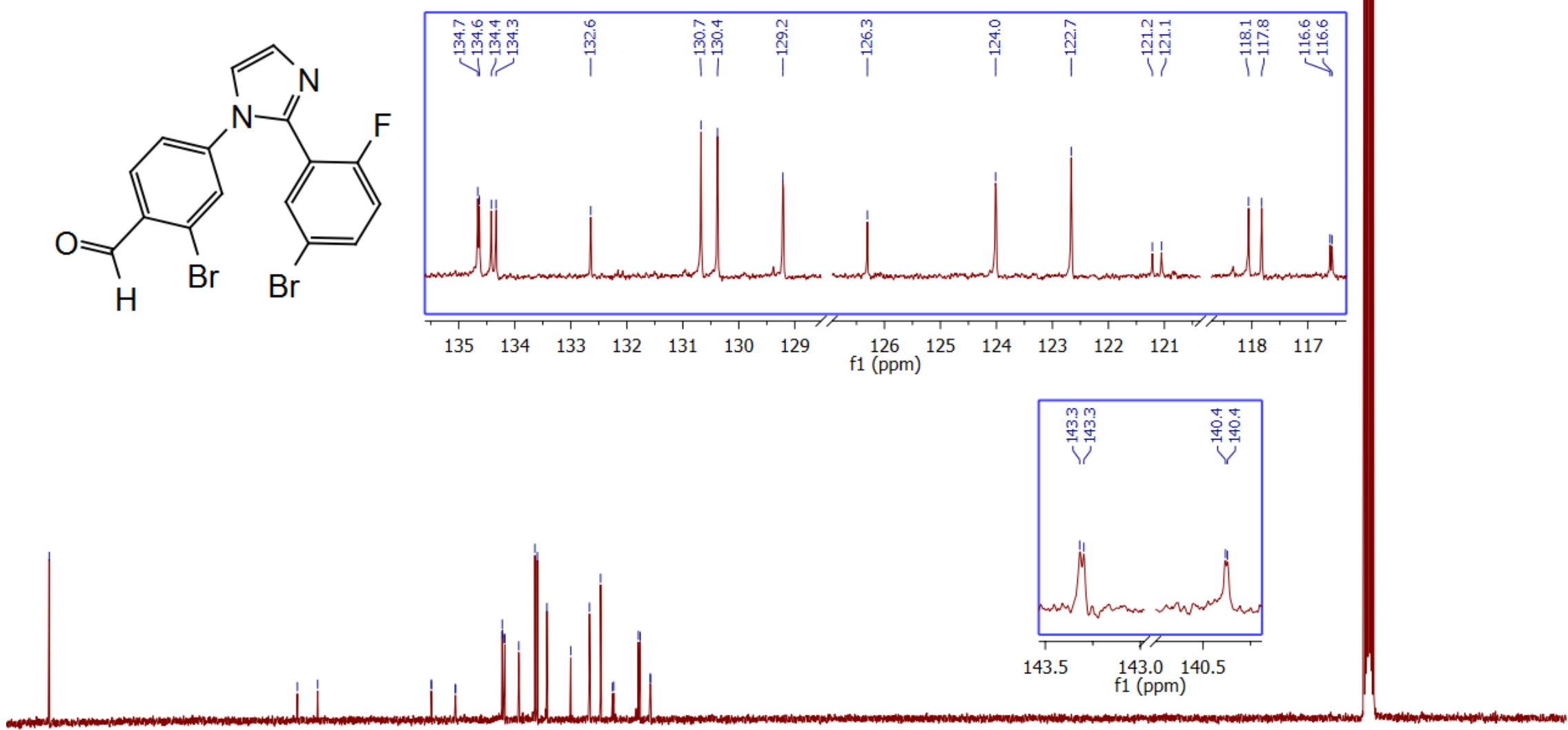


\section{Fragment 28}

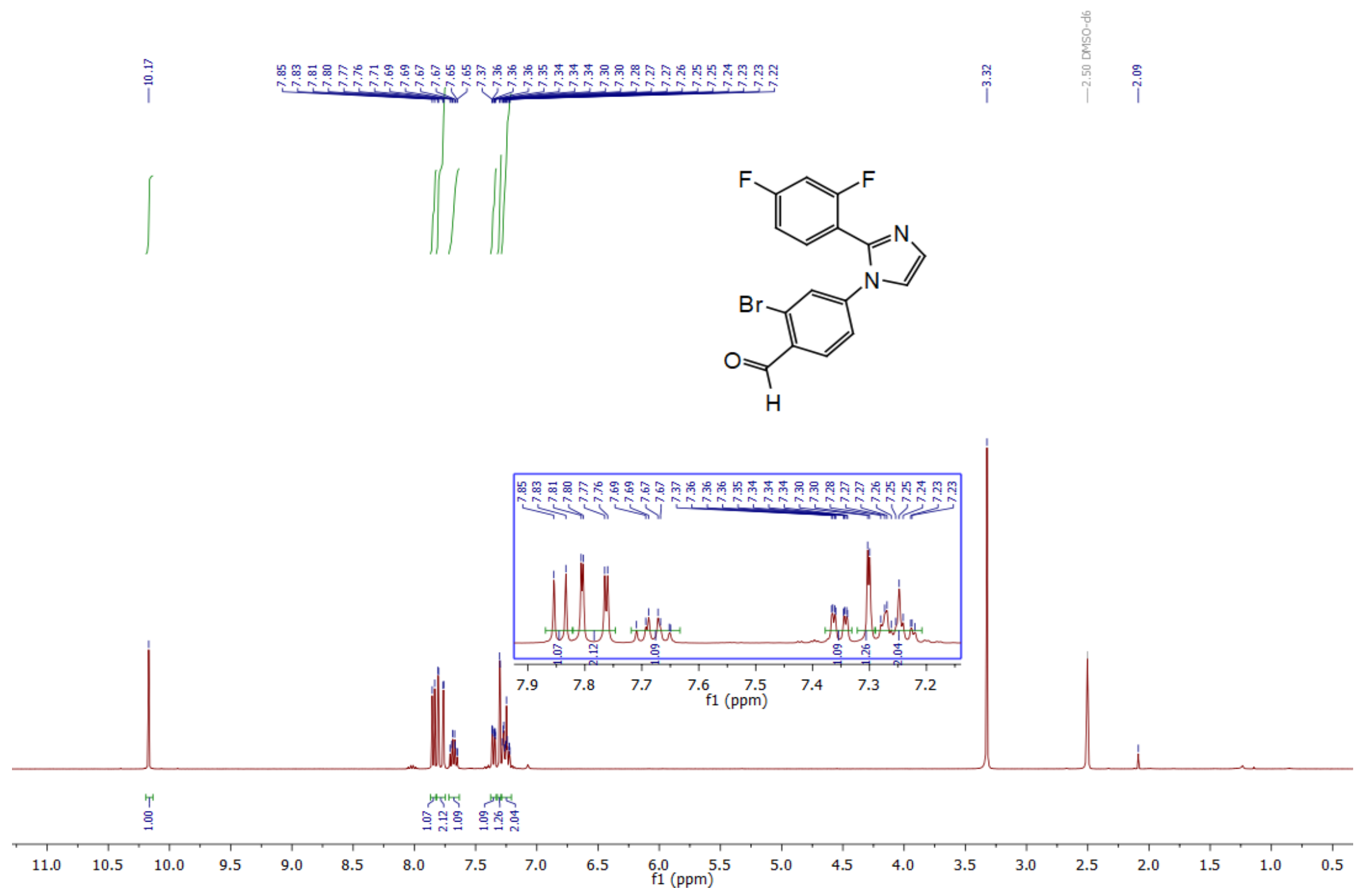




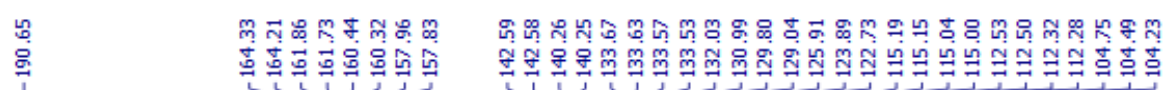

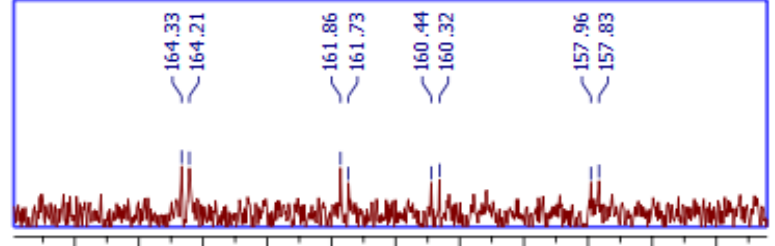

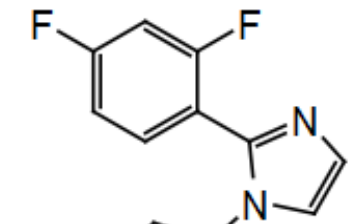

$\begin{array}{llll}159 & 158 & 157 & 156\end{array}$

f1 (ppm)

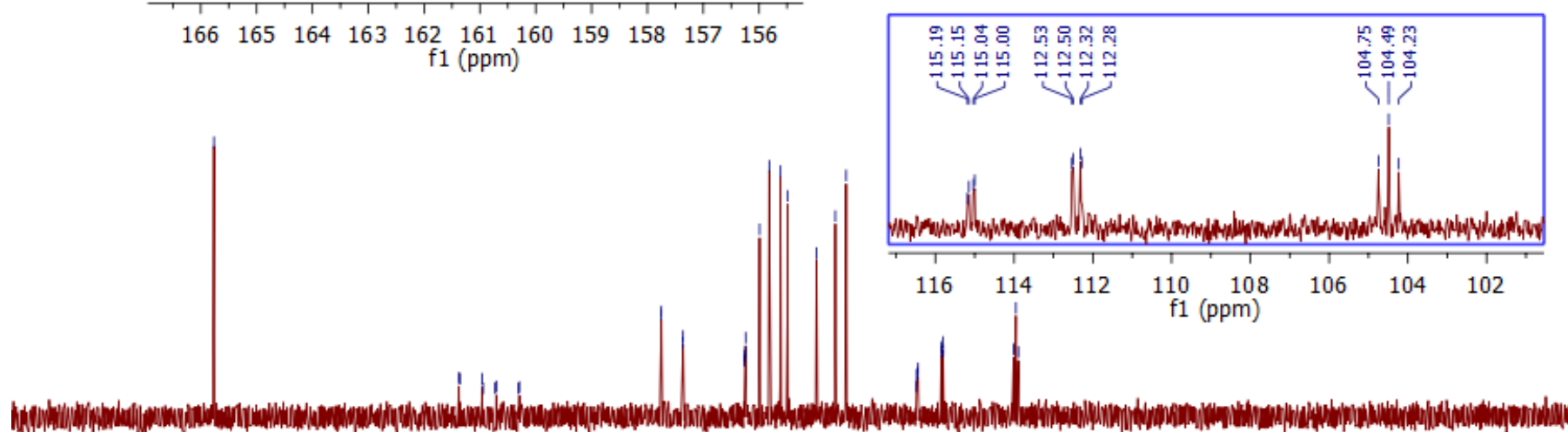

210

190

180

$160 \quad 150$

140

120

$110(\mathrm{ppm}){ }^{100}$

90

80

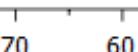

50

40

30

20

10 


\section{HPLC}

\section{Fragment 27}

D:Idatałusers_2021\Peter Cossar\PC2068B 10 RT: $0.00-10.00$

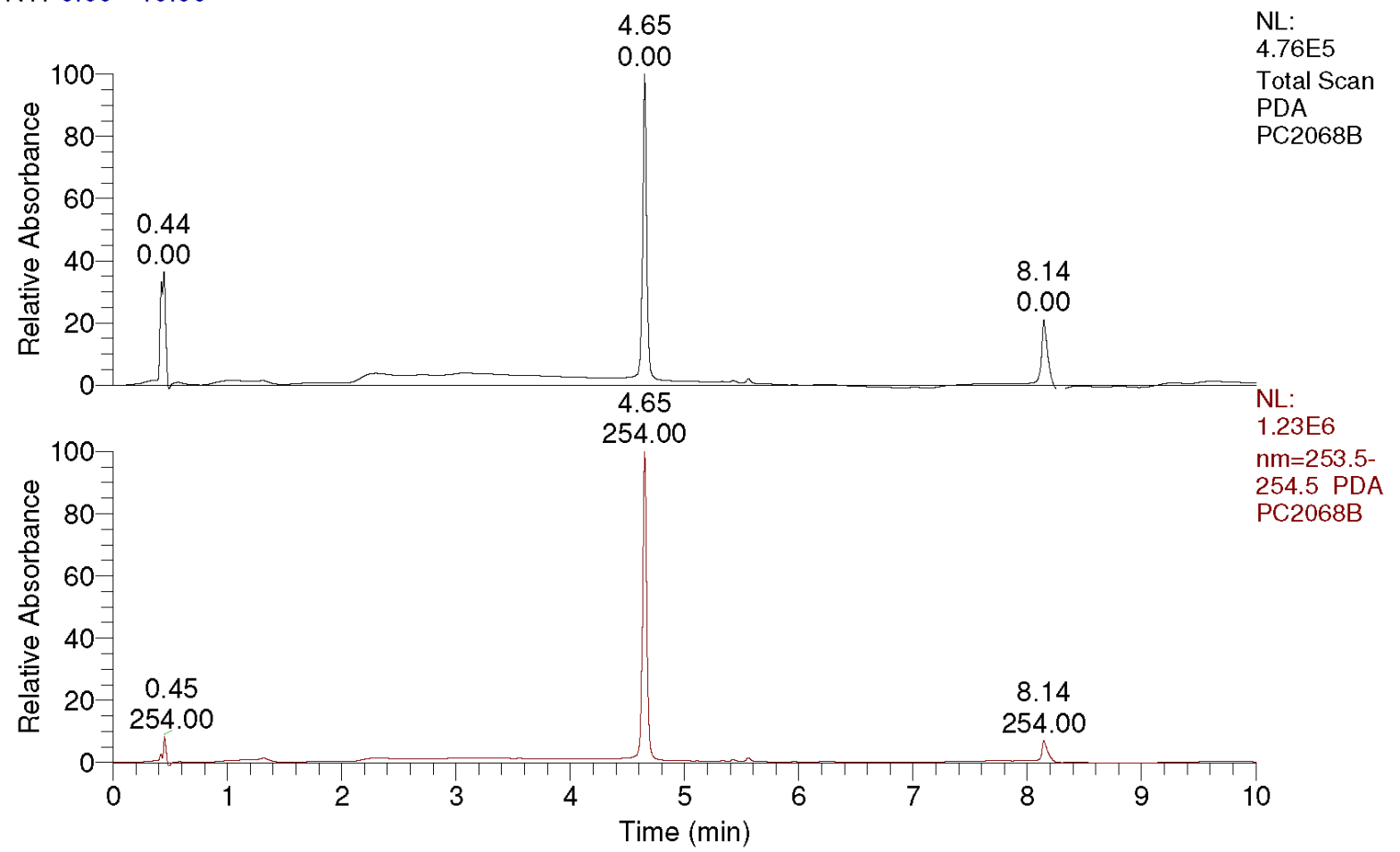

12/03/2021 19.32.29

D: methodsiCarlo Verhoefigeneral. meth

PDA

PC2068B

PC2068B \#384-414 RT: 4.64-4.88 AV: 31 SB: 18 0.81-1.03 NL: 6.59E4

T: ITMS + p ESI Full ms [100.00-1000.00]

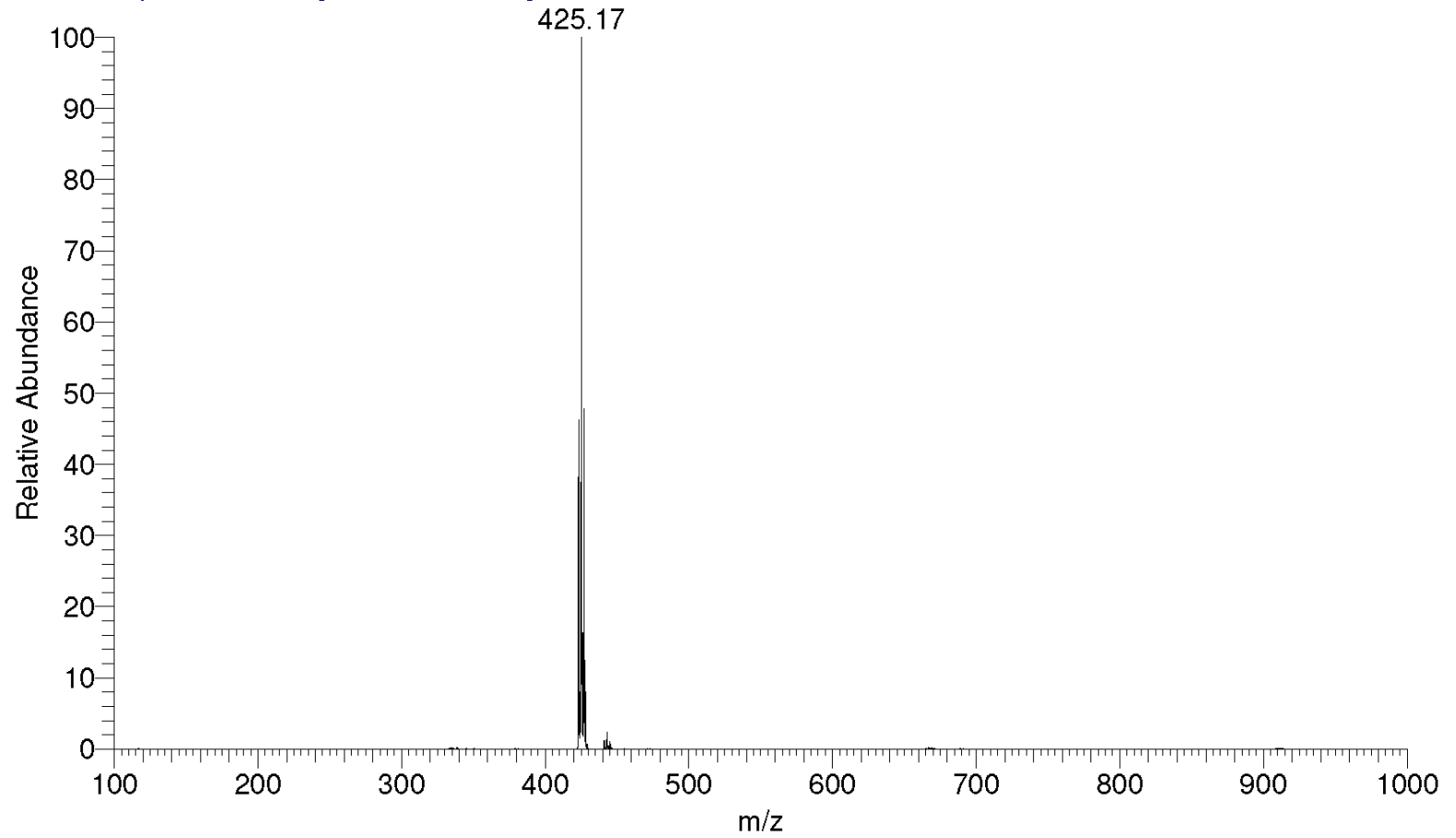




\section{Fragment 28}

D Jdata \.PC2068A 210504190621 66 RT: $0.00-10.00$

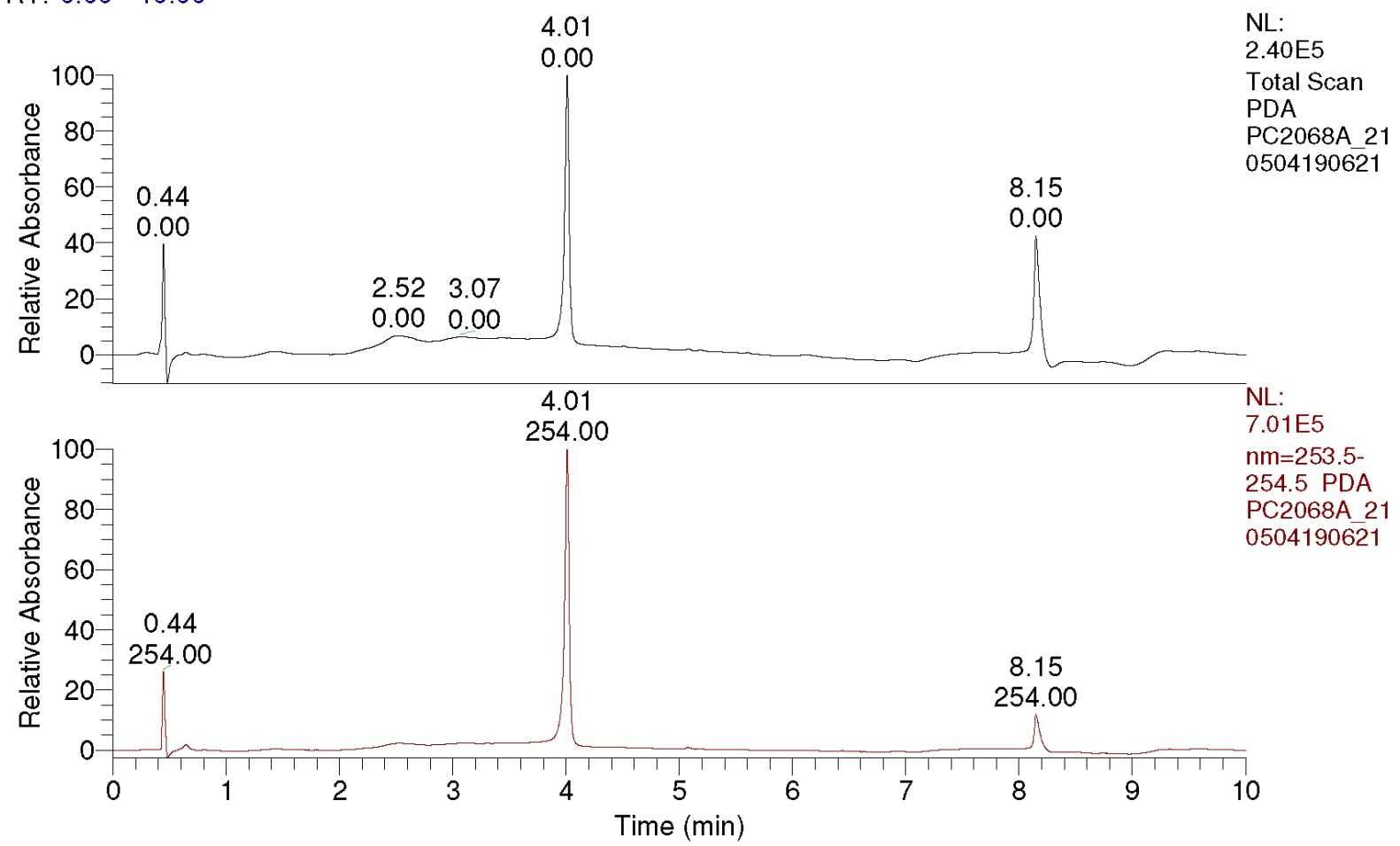

04/05/2021 19.06:21

D: methodsigeneral.meth

PC2068A 21

0504190621

PC2068A_210504190621 \#318-354 RT: 3.91-4.21 AV: 37 SB: 18 0.81-1.03 NL: 2.57E4

T: ITMS + p ESI Full ms [100.00-1000.00]

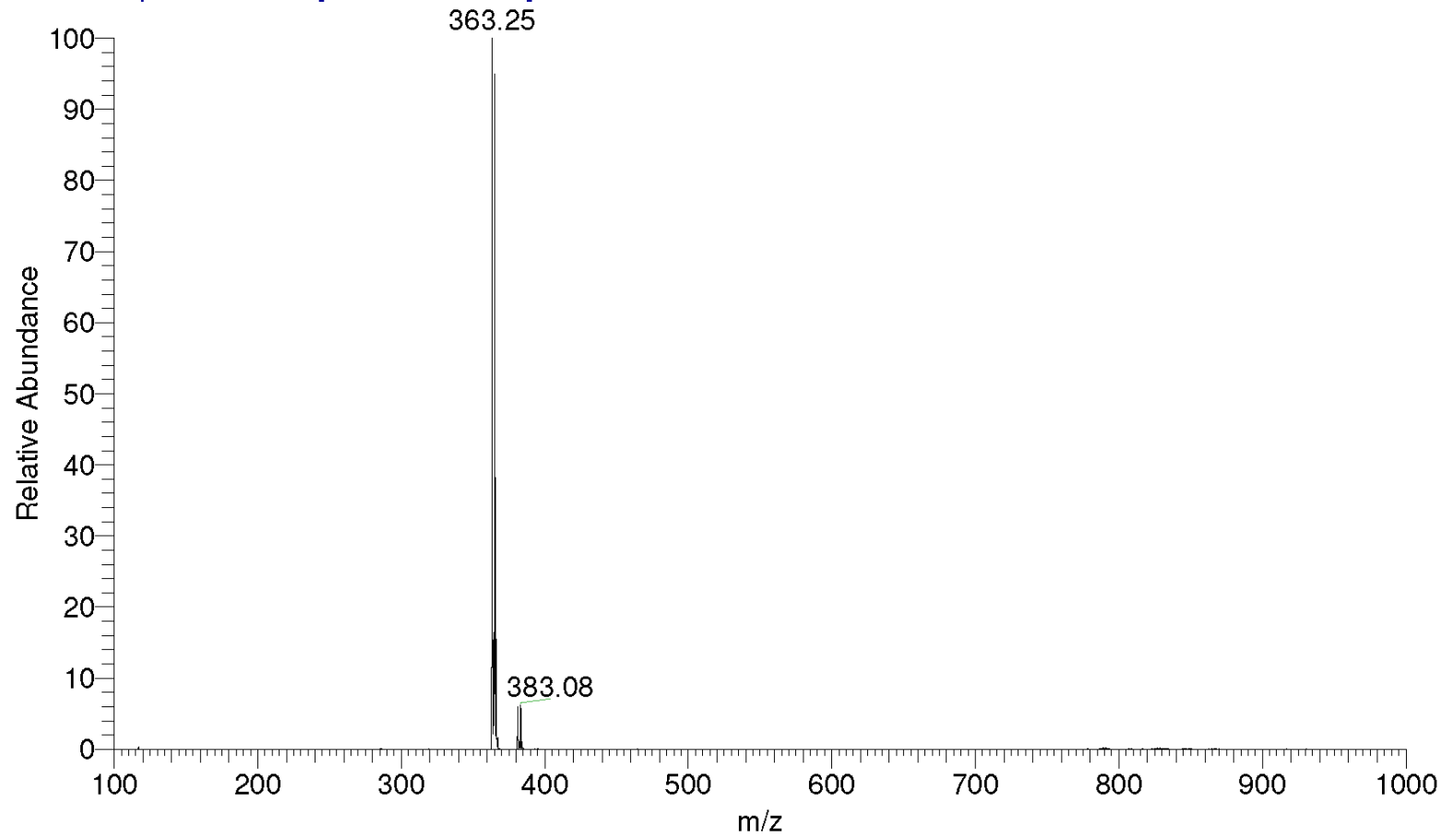




\section{References}

(1) Clabbers, M. T. B.; Gruene, T.; Parkhurst, J. M.; Abrahams, J. P.; Waterman, D. G. Electron Diffraction Data Processing with DIALS. Acta Crystallogr. Sect. Struct. Biol. 2018, 74 (6), 506-518. https://doi.org/10.1107/S2059798318007726.

(2) Lebedev, A. A.; Vagin, A. A.; Murshudov, G. N. Model Preparation in MOLREP and Examples of Model Improvement Using X-Ray Data. Acta Crystallogr. D Biol. Crystallogr. 2008, 64 (Pt 1), 33-39. https://doi.org/10.1107/S0907444907049839.

(3) Vagin, A.; Teplyakov, A. Molecular Replacement with MOLREP. Acta Crystallogr. D Biol. Crystallogr. 2010, 66 (1), 22-25. https://doi.org/10.1107/S0907444909042589.

(4) Emsley, P.; Cowtan, K. Coot: Model-Building Tools for Molecular Graphics. Acta Crystallogr. D Biol. Crystallogr. 2004, $60 \quad$ (12), 2126-2132. https://doi.org/10.1107/S0907444904019158.

(5) Murshudov, G. N.; Skubák, P.; Lebedev, A. A.; Pannu, N. S.; Steiner, R. A.; Nicholls, R. A.; Winn, M. D.; Long, F.; Vagin, A. A. REFMAC5 for the Refinement of Macromolecular Crystal Structures. Acta Crystallogr. D Biol. Crystallogr. 2011, 67 (Pt 4), 355-367. https://doi.org/10.1107/S0907444911001314.

(6) Adams, P. D.; Afonine, P. V.; Bunkóczi, G.; Chen, V. B.; Davis, I. W.; Echols, N.; Headd, J. J.; Hung, L.-W.; Kapral, G. J.; Grosse-Kunstleve, R. W.; McCoy, A. J.; Moriarty, N. W.; Oeffner, R.; Read, R. J.; Richardson, D. C.; Richardson, J. S.; Terwilliger, T. C.; Zwart, P. H. PHENIX: A Comprehensive Python-Based System for Macromolecular Structure Solution. Acta Crystallogr. D Biol. Crystallogr. 2010, 66 (2), 213-221. https://doi.org/10.1107/S0907444909052925.

(7) Wolter, M.; de Vink, P.; Neves, J. F.; Srdanovic, S.; Higuchi, Y.; Kato, N.; Wilson, A. J.; Landrieu, I.; Brunsveld, L.; Ottmann, C. Selectivity via Cooperativity: Preferential Stabilization of the P65/14-3-3 Interaction with Semi-Synthetic Natural Products. J. Am. Chem. Soc. 2020, 142 (27), 11772-11783. https://doi.org/10.1021/jacs.0c02151.

(8) Vink, P. J. de; Andrei, S. A.; Higuchi, Y.; Ottmann, C.; Milroy, L.-G.; Brunsveld, L. Cooperativity Basis for Small-Molecule Stabilization of Protein-Protein Interactions. Chem. Sci. 2019, 10 (10), 2869-2874. https://doi.org/10.1039/C8SC05242E.

(9) Stevers, L. M.; Lam, C. V.; Leysen, S. F. R.; Meijer, F. A.; van Scheppingen, D. S.; de Vries, R. M. J. M.; Carlile, G. W.; Milroy, L. G.; Thomas, D. Y.; Brunsveld, L.; Ottmann, C. Characterization and Small-Molecule Stabilization of the Multisite Tandem Binding between 14-3-3 and the R Domain of CFTR. Proc. Natl. Acad. Sci. U. S. A. 2016, 113 (9), E1152-1161. https://doi.org/10.1073/pnas.1516631113.

(10) Sijbesma, E.; Somsen, B. A.; Miley, G. P.; Leijten-van de Gevel, I. A.; Brunsveld, L.; Arkin, M. R.; Ottmann, C. Fluorescence Anisotropy-Based Tethering for Discovery of Protein-Protein Interaction Stabilizers. ACS Chem. Biol. 2020, 15 (12), 3143-3148. https://doi.org/10.1021/acschembio.0c00646. 